Winter 2005

\title{
Globalizing What: Education as a Human Right or as a Traded Service?
}

\author{
Katarina Tomasevski \\ Lund University
}

Follow this and additional works at: https://www.repository.law.indiana.edu/ijgls

Part of the Education Law Commons, Human Rights Law Commons, and the International Law Commons

\section{Recommended Citation}

Tomasevski, Katarina (2005) "Globalizing What: Education as a Human Right or as a Traded Service?," Indiana Journal of Global Legal Studies: Vol. 12 : Iss. 1 , Article 1.

Available at: https://www.repository.law.indiana.edu/ijgls/vol12/iss1/1

This Symposium is brought to you for free and open access by the Law School Journals at Digital Repository @ Maurer Law. It has been accepted for inclusion in Indiana Journal of Global Legal Studies by an authorized editor of Digital Repository @ Maurer Law. For more information, please contact rvaughan@indiana.edu.

\section{$\Psi$}

JEROME HALL LAW LIBRARY

INDIANA UNIVERSITY

Maurer School of Law
Bloomington 


\title{
Globalizing What: \\ Education as a Human Right \\ or as a Traded Service?
}

\author{
Katarina Tomasevski*
}

\section{INTRODUCTION}

Globalization tends to be described as an extralegal phenomenon. ${ }^{1}$ This image does not apply to education for which there is international law, albeit composed of two parallel and disconnected legal regimes. International human rights law defines education as a human right; international trade law defines it as a service. ${ }^{2}$ International human rights law is older than the law on trade in services, and domestic educational laws tend to be even older. ${ }^{3}$ Most of these define educa-

* Professor of International Law and International Relations at Lund University, educated at Harvard Law School and the University of Zagreb (Croatia); Special Rapporteur on the right to education of the United Nations Commission on Human Rights in 1998-2004; founder of the Right to Education Project. See http://www.right-to-education.org.

1. The elimination of barriers, including legal, to the free flow of goods, services, and capital, forms core support to the process of globalization. For education, such barriers include provision of education as government responsibility corollary to the right to education. In the words of Philippe Legrain, "huge swathes of the economy, such as public health and education, are typically provided by governments, and so closed to foreign companies." Philippe Legrain, Open World: The Truth A bout Globalization 110-11 (2002).

2. During the first stage of the development of indicators for education, the Organisation for Economic Co-Operation and Development (OECD) noted that "education is still a mainly public enterprise," although cost-sharing, that is, direct payments for the partial or full cost of education services, was "especially relevant at the beginning and ending stages of education-early childhood and tertiary education." See Centre for Educational Research and Innovation, OECD, Education AT a Glance: OECD Indicators 1998-94 (1998). In its examination of the state of the right to education in the world in 2000, the United Nations Educational, Scientific and Cultural Organization (UNESCO) has noted diverse and changing international commitments to the right to education, especially regarding the corresponding government obligation to make or keep education free, leading it to pose a question which remains unanswered: "what is the extent and depth of the international community's commitment to the principle of 'free' education?" UNESCO WORLD EDUCATION REport 2000 The Right to Education: Towards Education for all Throughout Life 23 (2000).

3. Fernando Reimers has thus summed up the historical background to the right to education:

The idea that all people should be educated is not new; it can be traced at least to the establishment of the Prussian State in the mid-eighteenth century. In the nineteenth century, several modern states adopted legislation that embraced compulsory pri- 
tion as compulsory and also as a right. ${ }^{4}$ Accordingly, they specify the corresponding governmental obligations. Large budgetary allocations for education reflect the legally defined extensive role of the state in education, ${ }^{5}$ and teachers are often the largest segments of the civil service. ${ }^{6}$ Against that role of the state in providing and/or financing education, globalization (defined as interaction across national borders unmediated by the state) fosters disengagement from education. The key facet of globalization, liberalization, is predicated on increasing the privatization of education, ${ }^{7}$ which demands decreased involvement of the state. In the 1990s,

mary education. Horace Mann, the proponent of the "common school," argued in the nineteenth century in the United States that education could be the "great equalizer [...] the balance wheel of the social machinery." The most significant expansion in access to education around the world at all levels has taken place during the last 100 years. Educational opportunity thus came to be perceived, in the collective consciousness of many in the middle of this century, both as a fundamental human right and as a gateway to social opportunity.

Fernando Reimers, Educational Chances of the Poor at the End of the Twentieth Century, 29 ProsPECTs 481, 481-82 (1999) (citation omitted).

4. Angela Melchiorre's analysis of government reports under the Convention on the Rights of the Child has revealed that out of 156 countries encompassed by her study, education is not compulsory by law in only 25. Angela Melchiorre, At What Age? ... Are School-Children Employed, Married, and Taken To Court?, Right to Education Project 4-5 (2004), available at www.right-to-education.org (last visited Jan. 25,2005). My own survey of all written constitutions in 2001 has shown that the right to education is guaranteed in 142 constitutions, while 44 countries have no constitutional guarantee. United Nations, Economic and Social Council, Commission on Human Rights; Report by Special Rapporteur Katarina Tomasevski If 66, U.N. Doc. EJ CN.4/2001/52/Add.1 (2001). A similar review within the World Bank has shown that 116 constitutions guarantee the right to education, and out of these, 95 stipulate that education should be free. Varun Gauri, Social Rights and Economics: Claim to Health Care and Education in Developing Countries, World Bank Policy Research Working Paper No. 3006, at 1 (2003).

5. Vito Tanzi, of the International Monetary Fund, and Ludger Schuknecht, of the European Central Bank, have concluded that the importance of education as "one of the core activities of government" has become "almost unquestioned," as reflected in persistently high budgetary allocations. "Public expenditure on education is one of the most important expenditure categories in governments' budgets. It averages about 6 percent of GDP in industrial countries." VITO TANZI \& Ludger Schuknecht, Public Spending in the 20th Century: A Global Perspective 184 (2000).

6. The UNESCO Institute for Statistics (UIS) and OECD found within their World Education Indicators (WEI) Programme in 2001 that teachers constituted a sizeable percentage of the national labor force, ranging between 1 in 25 to 1 in 10 employed persons. Organisation for Economic Co-Operation and Development, Teachers for Tomorrow's Schools: Analysis of the World Education Indicators 26 (2001).

7. Subjecting education to free-market rules relieves governments of the necessity to allocate to it significant parts of their budgets, but the consequence is that "only those who could afford to pay tuition fees could enrol" and thus, "income inequalities would be preserved from one genera- 
this facet was built into the international law on trade in services, resulting in two conflicting legal regimes for education. International human rights law mandates state intervention, requiring it to ensure, at least, free and compulsory education for all children. International law on trade in services legitimates the sale and purchase of education, excluding those who are unable to purchase it, thereby jeopardizing the key human rights requirements that at least primary education should be free and compulsory.

This article examines the practice of states in accommodating this legal duality of education. It focuses on the developing regions and countries in transition ${ }^{8}$ because the poverty of families, communities, and countries precludes access to education for many, if not most, unless education is free, namely provided or financed by the state. Its point of departure is international human rights law, which defines human rights-including the right to education-as universal. Its translation into reality would entail a minimum entitlement to education throughout the world, to be secured through international cooperation. Thereby governments would collectively comply with their human rights obligations. Consequently, globalization of education would be guided by a universal human rights obligation to ensure that education is free and compulsory for all school-age children in the world. However, the creation of international human rights law during the Cold War divided human rights into civil and political on the one hand, and economic, social, and cultural, on the other hand. Although education belongs in both categories, it also has been categorized as an economic, social, and cultural right. Its civil and political dimensions require respect of freedom; its social and economic dimensions mandate state provision and/or financing of education, while education as a cultural right often necessitates its affirmation as a collective right. ${ }^{9}$

tion to the next since education is itself a determinant of lifetime income." George Psacharopoulos \& Maureen Woodhall, Education for Development, An Analysis of Investment Choices 137 (1985).

8. No analysis of the situation in the developed or post-industrializing countries is included in this text because this would have exceeded space limitations due to the substantial role of the state. Not only that, but also, compulsory education is provided as a public responsibility, and it reaches far beyond primary schooling. The UNESCO-UIS has depicted the difference by pointing out that a European child can today aspire to 18 years of education, while this may be merely 3 years for an African child. Comparing Education Statistics Across the World, 2004 Global Educ. Digest, at 9 (Jan. 20, 2004), available at http://www.unesco.org/education/docs/EN_GD2004_v2.pdf (last visited Jan. 25, 2005).

9. These different facets of the right to education have been explained elsewhere. See Katarina Tomasevski, Manual on Rights-Based Education: Global Human Rights Requirements MAdE Simple (2004). 
For the majority of countries in the world that recognize economic, social, and cultural rights, ${ }^{10}$ the corresponding human rights obligations presuppose governments' willingness and ability to raise revenue and devote the maximum available resources to human rights. An important aim is to ensure that education is free at the point of use, at least for compulsory education. Therein originates the conflict of laws. While international human rights law recognizes every child's entitlement to free education, international trade law makes access to education dependent on the ability to pay. "Free trade does not have safeguards for the rights of the poor, least of all, for poor children. Hence, state intervention to safeguard free education for the millions of poor children necessitates corrective steps for the free market in education, facilitated by international cooperation. However, global development finance policies work in the opposite direction, as does trade in educational services. ${ }^{12}$ These counterpoised pressures, especially upon the governments of poor, impoverished, or indebted countries, result in an increasing incidence of for-fee rather than free education.

10. The impact of the Cold War on dividing human rights-including the right to educationinto civil and political on the one hand, and economic, social, and cultural on the other hand, is dealt with elsewhere. See Katarina Tomasevski, Education Denied: Costs and Remedies 64-66 (2003). The end of the Cold War has not brought this division to an end. The government of the United States remains opposed to the notion of economic, social, and cultural rights, claiming, for example, that "the communist system promised to fulfill economic, social and cultural rights but failed to deliver them." Statement of the United States of America to the 59th Commission on Human Rights, Delivered by Richard Wall, U.S. Public Delegate (Apr. 4, 2003), available at http://www.humanrights-usa.net/2003/statements/0407Item 10 .htm (last visited Feb. 4, 2005). The U.S. government uses the vocabulary of "access" and "service" with regard to education, and has thus summarized its position: "[a]t best, economic, social and cultural rights are goals that can only be achieved progressively, not guarantees. Therefore, while access to food, health services and quality education are at the top of any list of development goals, to speak of them as rights turns the citizens of developing countries into objects of development rather than subjects in control of their own destiny." United Nations, Economic and Social, Council, Commission on Human Rights; Report of the Open-Ended Working Group on the Right to Development at 46, U.N. Doc. E/CN.4/2001/26(2001).

11. Commonwealth Secretariat, Business Guide to the General Agreement on Trade in Services (2000).

12. The Asian Development Bank has acknowledged that globalization impedes governments' commitment to the right to education:

Globalization tends ... to direct governments away from equity-driven reforms for two main reasons. The first is that globalization increases the returns to high-level skills relative to lower-level skills, reducing the complementarity between equity- 
The phenomenon is not new; it was marked memorably by the United Nations International Children's Emergency Fund's (UNICEF) "Adjustment with a Human Face" almost twenty years ago. ${ }^{13}$ The chain of its causation is also not new and denies that education is a human right at its core. This article reviews the contemporary practice of states in promising and ensuring free education, comparing globally created legal and extralegal guidance for their conduct. International human rights law had been sidelined, if not undermined, through global development finance policies of the 1980s. Then, in the 1990s, international law on trade in education legally thwarted international human rights. As a result, there are quite a few countries where education is both a right and a traded service. The overlap of and the boundary between free and for-fee education in the developing regions form the focus of inquiry in this text. The main sources are governments' own legal and extralegal commitments. The former includes both human rights and liberalization of education; the latter addresses self-assessments and strategies in education as well as debt relief.

Within the law, progressive liberalization of trade in educational services supplants the requirement of human rights law for the progressive realization of the right to education. Beyond the law, global development finance policies mold education in the majority of countries in the world. The World Bank is the largest multilateral source of funding for education, as well as one of the key actors in forging global education and debt relief strategies. ${ }^{14}$ However, the World

and competitiveness-driven reforms. The second is that in most developing countries and in many industrial countries, finance-driven reforms dominate education change in the new globalized economic environment, and such reforms tend to increase inequity in the delivery of education services.

Special Chapter: Education for Global Participation, in Asian Development Bank - Key IndicaTors 2003, 43 (34th ed. 2003), available at http://www.adb.org/Documents/Books/Key_Indicators/ 2003/pdf/theme_paper.pdf (last visited Jan. 25, 2005).

13. Adjustment with a Human Face: Protecting the Vulnerable and Promoting Growth (Giovanni Andrea Cornia et al. eds., 1987).

14. Out of about US $\$ 5$ billion in total, bilateral aid to education amounted to US $\$ 4$ billion in 2001 , compared with US\$1.5 billion lent by the World Bank. EFA Global Monitoring Report Team, Gender and Education for All, The Leap to Equality 243 (UNESCO 2003), available at http// portal.unesco.org/education/en/ev.php-URLID=23023\&URL DO=DO TOPIC\&URL SECTION $=201 . \mathrm{html}$ (last visited Jan. 26, 2005).

The amount of aid alone is not a key consideration. Rather, it is influence over national educational policies through the process of defining which ones are "sound," namely worthy of inter- 
Bank is not bound by law nor does it acknowledge that education is a human right. ${ }^{15}$

Not all global educational strategies mention that education should be free, and none mentions that it should be compulsory, which indicates that they are not informed by international human rights law. School enrollment and completion can be attained through private education (or payments for public schooling, which should be, but is not, free), but those unable to pay are excluded. They figure in global educational statistics among the estimated millions of children who are out of school. ${ }^{16}$ Global development finance policies translate educational strategies from rhetorical to effective fiscal commitments, and thus, have a crucial role to play in securing education for those unable to afford it. Those polices also are not informed by international human rights law.

national endorsement and thus, political and financial support. The World Bank ensures "integration of education policies and programs within country-wide macro-economic and development strategies such as Poverty Reduction Strategies." Co-Chair Summary, Education For All-Fast Track Initiative Partnership Meeting If 8 (World Bank), Nov. 10-11, 2004, available at hitp:// www. 1.worldbank.org/education/efafti/documents/Brasilia/Brasiliacochairsummary. pdf.) (last visited Jan. 25, 2005).

15. This anomaly was described by the then-legal counsel, Ibrahim Shihata, regarding the remit of World Bank's Inspection Panel when he pointed out in 1997 that the Panel's remit was confined to "the Bank's failure to meet its standards, which are only required by itself and not by any binding rule of law." United Nations, Economic and Social Council, Commission on Human Rights; Annual Report of the Special Rapporteur on the Right to Education at 1516, U.N. Doc. E/CN.4/2001/52 (2001) (citation omitted). The "interpretation" has affirmed the full exemption of the World Bank from any judicial scrutiny because it enjoys legal immunity before domestic courts and no international litigation has ever been attempted. A unique situation thus persists where the World Bank is apparently bound only by those rules which it has created for itself, which is a considerable challenge for all advocates of the rule of law. See id.

16. The estimates of the number of out-of-school children vary. In 1996, the estimate of the number of children aged 6-11 was 110 million according to UNESCO/EFA and 140 million according to UniceF. International Working Group on Education, Selected Issues in Development Assistance to Education: A Report from the IWGE 35-37 (UNESCO 1997). In 2003, the EFA estimate was lowered to 104 million (from 115 million in 1999), because some large countries, such as China and India, diminished the size of school-going child population by moving the starting age for school from 6 to 7 years. Gender and Education for All, The Leap to Equality, supra note 14, at 49.

UNICEF's estimate of the number of out-of-school children remained considerably higher in 2003-121 million-because its sources reached beyond enrollment statistics to supplementary sources, such as household surveys, which furnished information on whether the formally enrolled children actually attended school. Carol Bellamy, The State of the World's Children 2004: Girls, Education and Development 7 (UNICEF 2003), available at http://www.unicef.org/ sowc04/files/SOWC_04_eng.pdf (last visited Jan. 25, 2005). 
Direct payments emerged in public compulsory education through globally designed, structural adjustment programs in the 1980 s and have taken root. ${ }^{17}$ There have been too few human rights challenges as yet, although the conflict of laws is painfully clear. Where education is defined as a traded service, direct charges form part of a private contract. Where similar charges are imposed in public education, they defy and often violate human rights law, blurring the boundary between free and for-fee, public and private education, and public and private law. In many countries such charges supplement, and sometimes substitute for, inadequate budgetary funding of education. Children, who are the prioritized subjects of the right to education, have no oppurtunity to alter, or even to challenge the exogenous influences, which deny what should be their birthright. Global education strategies have promised only primary education, and even that minimum is threatened as direct charges have spread to at least ninety-two countries in the world, as research results summarized in this text show. However, increasing global commitments to human rights mainstreaming and the rollback of user fees in public primary schooling provide an opportunity for challenge and rights-based change. Its conceptual underpinning is the global consensus on the role of education in reducing poverty, which is impossible if all those who are too poor to afford education-their principal ladder out of poverty-are excluded because they lack purchasing power.

This article first reviews changes within international law, pointing out the advent of international trade in educational services and noting that negotiations about further liberalization of trade in education are ongoing. Since the majority of countries have not made any liberalization commitments yet, there is time for reaffirming the right to education. The practice of states, including their opinio juris in their liberalization commitments, overwhelmingly supports children's right to free and compulsory education. ${ }^{18}$ This opens the way for introducing

17. Tomasevski, supra note 10, at 69-82 (discussing the changing parameters of the debate about global public education).

18. A UNESCO initiative in interviewing 13 ministers of education from developing regions and countries in transition, so as to detect key problems and challenges in education, in February 2004 , revealed opposition to transforming education from a public into a traded service. The Minister for Education of Brazil, Cristovam Buarque, thus expressed his government's view: "We don't think that education is a merchandise and we're not in favour of the WTO position which aims to make education into one." Kader Asmal, the Minister for Education of South Africa, added:

I think we were one of the first countries to oppose the WTO decision. We have our own priorities for training and education, and we will not concede to opening up 
human rights correctives in the international law on trade in education. This article then turns to extralegal determinants of national educational laws and policies to ask whether for-fee and free public primary educational choices are policyor poverty-based. Governmental reports required by human rights treaties are used as a key source, and they show that most governments highlight their inability, rather than unwillingness, to make or keep primary education free. Very few express their willingness to convert primary education into a traded service. $\mathrm{Ob}$ stacles to the realization of the right to free education are examined next. The focus is on user charges in primary education and on the role of the World Bank in their introduction and justification. A global stocktaking of direct charges in public primary schooling based on primary sources follows. Governmental reports as the principal source of data required by human rights treaties are supplemented by reports on education and debt relief. Regional overviews highlight the concordance and discord between legal guarantees of free education and the current practice of states. The findings highlight how the incidence of direct charges does not depend only on the relative poverty of the particular country and region, as is often assumed. The government's commitment to free public education and global support for that commitment play the decisive roles. The rollback of user fees with new or revived governmental commitments to free public primary education illustrates the potential for change. This article points out obstacles to further mobilization for change, suggests how these could be overcome, and emphasizes the contribution that applied human rights research can make in buttressing the increasing global commitment to human rights mainstreaming in global education and development finance strategies.

\section{Changes Within International LaW}

Education acquired a double, mutually contradictory, legal status in the 1990s, when it became a traded service. ${ }^{19}$ Primary and/or compulsory education continues

our country to investment on a non-discriminatory basis. We have to support our public education system and give it subsidies.

Education Ministers Speak Out, Educ. TODAY, Jan./Mar., (UNESCO 2004), available at http// portal.unesco.org/education/en/ev.php-URL_ID $=27722 \%$ URL_DO $=$ DO_TOPIC\&URL_ SECTION=201.html (last visited Jan. 25, 2005).

19. See United Nations, Economic and Social Council, Commission on Human Rights; Annual Reports of the Special Rapporteur on the Right to Education at 8-9, U.N. Doc, EJ CN.4/2003/9 (2003); see also United Nations, Economic and Social Council, Commission on 
as a public service in most countries, albeit for-fee in many, while post-compulsory education is increasingly sold and purchased for a price. The liberalization commitments under the General Agreement on Trade in Services (GATS) ${ }^{20}$ have affirmed the option to preserve compulsory education as a free public service and the corresponding individual entitlement. ${ }^{21}$ The exercise of this choice by individual states merges the proverbial political willingness, which makes or breaks human rights, with pressures nudging governments in the opposite direction. The pressures originate in requirements to reduce budget deficits, and thus public funding of education, as well as to open the educational markets to exporters of educational services. ${ }^{22}$

Human Rights; Annual Report of the Special Rapporteur on the Right to Education at 10 , U.N. Doc. E/CN.4/2002/60 (2002) (stating that developments in international trade law give rise to a need for reaffirming that education is a human right); UNITEd Nations, Economic and Social Council, Commission on Human Rights; Annual Report of the Special Rapporteur on the Right to Education at 20, U.N. Doc. E/CN.4/2001/52 (2001) (explaining that when the world's focus is on new commercialized forms of education, it is necessary to think about values that need protection and to contemplate the consequences of choices to be made); UNITED NAtions, Economic and Social Council, Commission on Human Rights; Progress Report of the Special Rapporteur on the Right to Education at 24-25, U.N. Doc. E/CN.4/2000/6 (2000) (explaining that the presence of international trade in education services, which treats education as a commodity to be sold and purchased, necessitates a reaffirmation of education as a human right).

20. Different from trade in goods, there is no general obligation for states under GATS to extend either market access or national treatment regarding trade in services. These obligations are negotiated on a sector-by-sector basis, and form a discrete schedule of commitments made by each state regarding foreign services and their suppliers with respect to a specific service sector. European Commission, GATS-The General Agreement on Trade in Services: A Guide for Business 30, 32 33 (1995). However, the objective of GATS, as expressed in the preamble, is to achieve "progressively higher levels of liberalization of trade in services through successive rounds of multilateral negotiations." General Agreement on Trade in Services, Apr. 15, 1994 [hereinafter GATS].

21. The initial background note on education for the Council for Trade in Services, prepared by the WTO Secretariat in September 1998, noted its exemption from free-trade rules because much of education tended to be provided "free of charge or at prices not reflecting the costs of producing it." This was a consequence of considering "instruction up to a certain level-commonly primary and secondary education-as a basic entitlement." Hence, the WTO Secretariat concluded: "Basic education provided by the government may be considered to fall within the domain of the terminology of the GATS, services supplied in the exercise of governmental authority (supplied neither on a commercial basis nor in competition)." Background Note by the Secretariat for the Council in Trade of Services: Education Services, WTO S/C/W/49 II 9, 12-13 (1998).

22. Jane Knight has thus described the change in the 1990s:

With the massification of higher education increasing at an exponential rate, there is strong interest on the part of large and small countries to make the export of education products and services a major part of their foreign policy. In fact, we see major shifts in 
The two parallel legal regimes of education are mirrored in the corresponding literature, which either deals solely with education as a human right ${ }^{23}$ or examines only educational services provided on a commercial basis. ${ }^{24}$ However, international human rights law and international trade law overlap, and more importantly, conflict. The boundary between free and for-fee education is set differently in domestic laws; this legal duality is new. In many countries, the free/for-fee boundary coincides with the end of compulsory education, which marks the end of education as an individual entitlement under public law and the beginning of education that is regulated by private law as a commercial transaction. In quite a few countries, that boundary is blurred. The reasons for this vary. In some countries, constitutional guarantees of education define it as freedom of parents and communities to provide and finance it, and not as a government's commitment to make it free or compulsory. In many countries, although there is a legal guarantee of free and compulsory education, public primary education, which should be free, is only accessible through the payment of direct charges. ${ }^{25}$

Education as an internationally traded service generates immense profits

foreign policies where education was primarily seen as a development assistance activity or cultural programme to one where education is an export commodity.

Jane Knight, Internationalisation of Higher Education, in Quality and INTERNaTIONALISATION in Higher Education 18 (OECD 1999).

23. See generally Douglas Hodgson, The Human Right to Education (1998) (giving an overview of the right to education's development at international and regional levels).

24. See generally James Tooley, The Global Education Industry: Lessons from Private Education in Developing Countries (2d ed. 2001) (showing why and where the private education sector is thriving and exposing hindrances to its progress). In a subsequent publication, James Tooley made his position explicit. Taking "the crucial role of markets in our lives" as his point of departure, he asked: "Why should education be an exception?" James Tooley \& Pauline Dixon, Private Schools for the Poor: A Case Study from India 23 (2003).

25. The apparent contradiction between a constitutional guarantee of free public education and the practice of imposing charges is widespread, as this text shows through regional overviews below, but the knowledge about this practice is inadequate in most countries. One reason is that international educational statistics record and compare only government and/or public expenditure on education, effectively leaving private payments invisible. See Mark Bray, The Costs and Financing of Education: Trends and Policy Implications (2002). Another closely related reason is the lack of incentive for governments to determine and publicize the private payments for the nominally (but not really) free public education. These would have to be supplanted through increased public funding in order to make education genuinely free, which would be contrary to policy choices in many countries. People's Republic of China represents an illustrative example. United Nations, Economic and Social Council, Commission on Human Rights; Katarina Tomasevski-Economic, Social, and Cultural Rights: The Right to Education Addendum If 17-18, U.N. Doc. E/CN/2004/45/Add.1 (2003). 
for a few countries. ${ }^{26}$ Predictably, the exporters of education services have set the tone of negotiations under GATS, pushing other World Trade Organization (WTO) members toward liberalization. For the United Kingdom, the annual value of the export of education services was estimated in 1999 at up to $£ 12$ billion. ${ }^{27}$ In the United States, more than $\$ 11$ billion was generated in $2000-2001$ by foreign students. This figure does not account for the estimated commercial value of the export of U.S. educational services to more than 100 countries. ${ }^{28}$ In comparison, the U.S. aid for education allocated to developing countries is $\mathrm{mi}-$ nuscule, estimated at an annual $\$ 1.45$ billion. ${ }^{29}$ Moreover, the boundary between international trade in education and aid for education has become blurred. In the 1990 s, Australia allocated 70 percent of its aid for education to scholarships for foreign university students studying in Australia, while French aid for education benefited some 100,000 foreign students in France and 8,000 French teachers working in French-speaking Africa. ${ }^{30}$

The abyss between knowledge-based and education-deficit regions and countries $^{31}$ is not likely to be narrowed spontaneously; it is likely to increase. Thus,

26. Global market shares in higher education for 2002 have been reported as $58 \%$ for the United States, 24\% for the United Kingdom, $10 \%$ for Australia, 7\% for Canada, and 2\% for New Zealand. Anthony Böhm et al., Vision 2020; Forecasting International Student Mobility: A UK Perspective 29 (2004).

27. United Nations, Economic and Social Council, Commission on Human Rights; Report by Katarina Tomasevski, Special Rapporteur on the Right to Education: Mission to the United Kingdom of Great Britain and Northern Ireland (England) - Addendum at 6, U.N. Doc. E/CN.4/2000/6/Add.2 (1999).

28. United Nations, Economic and Social Council, Commission on Human Rights; Report Submitted by Katarina Tomasevski, Special Rapporteur on the Right to Education: Mission to the United States of America - Addendum at 12, U.N. Doc. E/CN.4/2002/60/Add.1 (2002).

29. Global Campaign for Education, Education for All Fast Track: The No-Progress Report, at http:// www.oxfam.org.uk/what_we_do/issues/education/downloads/gce_noprogress.pdf (last visited Feb. 2, 2005).

30. International Working Group on Education (IWGE), Education Aid Policies and Practice, Meeting of the International Working Group on Education, Nice, France (Nov. 16-18, 1994).

31. The OECD has said that "the ability to create, distribute and exploit knowledge and information seems ever more important and is often regarded as the single most important factor underlying economic growth and improvements in the quality of life." OrGanisation for Economic Co-Operation and Development, Science, Technology and Industry Scoreboard 1999, Benchmarking Knowledge-Based Economies 7 (1999). What is sometimes called "human capital," namely the knowledge, skills, and competences relevant to economic activity, thus become crucial assets, albeit distributed unevenly between and within countries. Organisation for Economic Co-Operation and Development, Centre for Research and Innovation, Human CapiTAL INVESTMENT 9 (1998). 
defining the nature and scope of education that should remain exempt from trade and continue as a free public service attains increased importance when educational systems are "pressured into responding to the logic of free trade." 32 The question is whether we are heading toward progressive liberalization of trade in educational services or progressive realization of the right to education. As members of the delegation of New Zealand noted to the Council for Trade and Services, "the divide between public policy and commercial activity" is at stake. ${ }^{33}$

Negotiations are proceeding within the WTO under GATS, pursuant to which individual governments are opening particular services to international trade, with the general aim of "achieving a progressively higher level of liberalization." ${ }^{34}$ In the educational sector, there are two major types of commitments, market access and national treatment, ${ }^{35}$ aiming at what is called the "equal playing field" for domestic and foreign educational service providers. WTO members make commitments in each of the educational sub-sectors ${ }^{36}$ separately, and relatively few have been entered in the educational subsector, as Table 1 shows. That only forty-six states, less than one-third of WTO members, made commitments to liberalize their educational sectors indicates that education as government responsibility continues to enjoy support of more than two-thirds of WTO members. Even the liberalizers, such as the United States, have emphasized that trade should supplement rather than displace public education. ${ }^{37}$

32. S.L. Robertson et al., GATS and the Education Service Industry: The Politics of Scale and Global Reterritorialization, 46 Comp. Educ. Rev. 472, 495 (2002).

33. Negotiating Proposal for Education Services: Communication from New Zealand, WTO S/CSS/W/93, at 2 (June 26, 2001).

34. Preamble to GATS, supra note 20; Marrakesh Agreement Establishing the World Trade Organization, Annex 1B, Law and Practice of the World Trade Organization 341.

35. Market access commitments oblige governments not to impose limits on the number of foreign education service providers, the number of foreign personnel that may be employed, the legal forms of foreign-owned and/or based education service providers, or the use of foreign capital. A national treatment commitment is a commitment not to favor domestic education services so as not to distort competition.

36. Education is divided into five sub-sectors: primary, secondary, higher, adult education and "other education services." These are based on the classification list of sectoral services, which was elaborated during the Uruguay Round. That list was based on the so-called "CPC codes," namely the Central Product Classification as developed by the United Nations Statistical Commission. Background Note by the Secretariat for the Council for Trade in Services: Education Services, WTO S/ C/W/49, at 15-16 (Sept. 23, 1998).

37. Higher (Tertiary) Education, Adult Education, and Training: Communication from the United States, WTO S/CSS/W/23, at 1 (Dec. 18, 2000). 
Table 1: Liberalization commitments in education under the GATS

\begin{tabular}{|c|c|c|c|c|c|}
\hline \multirow[t]{2}{*}{ WTO member } & \multicolumn{5}{|c|}{ Commitments by sub-sector } \\
\hline & $\begin{array}{l}\text { Primary } \\
\text { Education }\end{array}$ & $\begin{array}{l}\text { Secondary } \\
\text { Education }\end{array}$ & $\begin{array}{l}\text { Higher } \\
\text { Education }\end{array}$ & $\begin{array}{l}\text { Adult } \\
\text { Education }\end{array}$ & $\begin{array}{l}\text { Other } \\
\text { Education }\end{array}$ \\
\hline Albania & $\sqrt{ }$ & $\sqrt{ }$ & $\sqrt{2}$ & $\sqrt{ }$ & $\sqrt{3}$ \\
\hline Armenia & & & $\sqrt{ }$ & $\sqrt{2}$ & \\
\hline Australia & & $\sqrt{ }$ & $\sqrt{ }$ & & $\sqrt{ }$ \\
\hline Austria & $\sqrt{ }$ & $\sqrt{ }$ & & $\sqrt{ }$ & \\
\hline Bulgaria & $\sqrt{ }$ & $\sqrt{ }$ & & $\sqrt{1}$ & \\
\hline Cambodia & & & $\sqrt{1}$ & $\sqrt{1}$ & $\sqrt{1}$ \\
\hline China & $\sqrt{ }$ & $\sqrt{ }$ & $\sqrt{ }$ & $\sqrt{ }$ & $\sqrt{ }$ \\
\hline Congo, D. R & & & $\sqrt{ }$ & & \\
\hline Costa Rica & $\sqrt{ }$ & $\sqrt{ }$ & $\sqrt{2}$ & & \\
\hline Croatia & & $\sqrt{ }$ & $\sqrt{ }$ & $\sqrt{ }$ & $\sqrt{ }$ \\
\hline Czech Republic & $\sqrt{ }$ & $\sqrt{ }$ & $\sqrt{ }$ & $\sqrt{ }$ & $\sqrt{ }$ \\
\hline Estonia & $\sqrt{ }$ & $\sqrt{ }$ & $\sqrt{ }$ & $\sqrt{1}$ & $\sqrt{ }$ \\
\hline European Community & $\sqrt{ }$ & $\sqrt{ }$ & $\sqrt{ }$ & $\sqrt{1}$ & \\
\hline Gambia & $\sqrt{ }$ & & & $\sqrt{1}$ & $\sqrt{ }$ \\
\hline Georgia & $\sqrt{ }$ & $\sqrt{ }$ & $\sqrt{ }$ & $\sqrt{ }$ & \\
\hline Ghana & & $\sqrt{ }$ & & & $\sqrt{ }$ \\
\hline Haiti & & & & $\sqrt{ }$ & \\
\hline Hungary & $\sqrt{ }$ & $\checkmark$ & $\checkmark$ & $\sqrt{ }$ & \\
\hline Jamaica & $\sqrt{ }$ & $\sqrt{ }$ & $\sqrt{ }$ & & \\
\hline Japan & $\sqrt{ }$ & $\sqrt{ }$ & $\sqrt{1}$ & $\sqrt{ }$ & \\
\hline Jordan & $\sqrt{ }$ & $\sqrt{ }$ & $\sqrt{ }$ & $\sqrt{ }$ & $\sqrt{2}$ \\
\hline Kyrgyzstan & $\sqrt{ }$ & $\sqrt{ }$ & $\sqrt{ }$ & $\sqrt{ }$ & \\
\hline Latvia & $\sqrt{ }$ & $\sqrt{ }$ & $\sqrt{ }$ & $\sqrt{ }$ & \\
\hline Lesotho & $\sqrt{ }$ & $\sqrt{ }$ & $\sqrt{ }$ & $\sqrt{7}$ & $\sqrt{ }$ \\
\hline Liechtenstein & 1 & $\sqrt{ }$ & $\sqrt{1}$ & 4 & \\
\hline Lithuania & $\sqrt{ }$ & $\sqrt{1}$ & $\sqrt{1}$ & $\sqrt{1}$ & \\
\hline Macedonia (FYROM) & & $\sqrt{ }$ & $\sqrt{ }$ & $\sqrt{ }$ & \\
\hline Mali & & & & $\sqrt{ }$ & \\
\hline Mexico & $\sqrt{ }$ & $\sqrt{ }$ & J & & $\sqrt{ }$ \\
\hline Moldova & $\sqrt{ }$ & $\sqrt{ }$ & $\sqrt{ }$ & $\sqrt{ }$ & $\sqrt{ }$ \\
\hline Nepal & & & $\sqrt{ }$ & $\sqrt{3}$ & $\sqrt{ }$ \\
\hline New Zealand & $\sqrt{ }$ & $\sqrt{ }$ & $\sqrt{ }$ & & \\
\hline Norway & $\sqrt{ }$ & $\sqrt{ }$ & $\sqrt{ }$ & $\sqrt{ }$ & $\sqrt{ }$ \\
\hline Oman & & $\sqrt{ }$ & $\sqrt{ }$ & $\sqrt{ }$ & $\sqrt{ }$ \\
\hline Panams & $\sqrt{ }$ & $\sqrt{ }$ & $\sqrt{ }$ & & \\
\hline Poland & $\sqrt{ }$ & $\sqrt{ }$ & $\sqrt{1}$ & $\sqrt{ }$ & \\
\hline Rwanda & & & & $\sqrt{ }$ & \\
\hline Sierra Leone & $\sqrt{1}$ & $\sqrt{ }$ & $\sqrt{ }$ & 7 & $\sqrt{2}$ \\
\hline Slovak Republic & $\sqrt{2}$ & $\sqrt{ }$ & $\sqrt{ }$ & $\sqrt{2}$ & $\sqrt{ }$ \\
\hline Slovenia & & $\sqrt{ }$ & $\sqrt{ }$ & $\sqrt{ }$ & \\
\hline Switzerland & $\sqrt{ }$ & $\sqrt{ }$ & $\sqrt{ }$ & $\sqrt{ }$ & \\
\hline Taiwan & $\sqrt{ }$ & $\sqrt{ }$ & $\sqrt{ }$ & $\sqrt{3}$ & $\sqrt{ }$ \\
\hline Thailand & 4 & $\sqrt{ }$ & & $\sqrt{ }$ & \\
\hline Trinidad and Tobago & & & $\sqrt{ }$ & & $\sqrt{2}$ \\
\hline Turkey & $\sqrt{3}$ & $\sqrt{ }$ & $\sqrt{ }$ & & $\sqrt{ }$ \\
\hline USA & & & & $\sqrt{ }$ & $\sqrt{ }$ \\
\hline Totals & 31 & 36 & 37 & 36 & 22 \\
\hline
\end{tabular}

Source: An earlier list of tiberalization commitments was included in UNCTAD/WTO International Trade Centre - Business Guide to the General Agreement on Trade in Services, Revised Edition, Geneva, 2000, pp. 81-83.

Updated information, by Andrew Egan for the Right to Education Project, can be found at www.right-to-education.org 
Liberalization commitments can be made for primary education by governments of countries where it is not universally available and is, accordingly, not compulsory. GATS allows exempting services provided "in the exercise of governmental authority," 38 which comprises public compulsory education in the domestic legislation of most countries. ${ }^{39}$ The legal situation is complicated and has not yet been addressed within GATS. International human rights law mandates parental freedom of choice for the education of their children, and thus disallows state monopoly over education. Indeed, public and private education coexist in most countries, as international human rights law mandates. Free parental choice can be exercised where free public education is guaranteed for all, and the option of private schooling broadens that choice. Where public education is not available or only exists as "poor education for the poor," ${ }^{40}$ that choice is not really a choice at all. Moreover, where public education should be free but is only accessible for payment, there is no choice at all.

Liberalization of trade in educational services without human rights correctives undermines the right to education, which requires ensuring that at least compulsory education is free of charge and available and accessible to all school-

38. Article 1, section 3 of GATS says that the term "services" includes any service in any sector except services supplied in the exercise of governmental authority, and then defines "a service supplied in the exercise of governmental authority" to mean "any service which is supplied neither on a commercial basis, nor in competition with one or more service suppliers." GATS, supra note 20, at art. I, §3.

39. An affirmation that education constitutes a right in many countries has been furnished by the WTO Secretariat: "Given its importance for human and social development, countries throughout the world tend to consider instruction up to a certain level, commonly primary and secondary education, as a basic entitlement. It is normally provided free of charge by public authorities and, in most countries, participation is mandatory. In addition, some degree of private participation in the supply, which varies among countries, exists as well. However, the underlying institutional arrangements may be very diverse, making the separation of public and private domains not always clear." Background Note by the Secretariat for the Council for Trade in Services: Education Services, WTO S/C/W/49, at 4 (Sept. 23, 1998).

40. Under-funded public education inevitably generates exodus from such "poor schools for the poor" to better-funded public or private schools by all parents who can afford to do so. This phenomenon can be seen in the United States. See United Nations, Economic and Social Council, Commission on Human Rights; Mission to the United States of America: Report by Special Rapporteur Katarina Tomasevski - Addendum III 40-49, U.N. Doc. E/CN.4/2002/60/Add.I (2002). This can also be seen in developing countries as well, such as Colombia. See UNited NAtions, Economic and Social Council, Commission on Human Rights; Mission to Colombia: Report by Special Rapporteur Katarina Tomasevsk1-Addendum 1 II 10-28, U.N. Doc. E/ CN.4/2001/45/Add.2 (2004). 
age children. In many developing countries and countries in transition, free public education is simply not available for all school-age children. ${ }^{41}$ Although this phenomenon is routinely attributed to poverty, ${ }^{42}$ the next section looks at global strategies that exacerbate poverty-based exclusion from education through policies that defy international human rights law.

\section{Changes Beyond the Law}

Law is not the key determinant of educational policy, especially in countries dependent on international development finance. The global consensus underpinning development commitments covers only primary education as a long-term developmental goal, to be attained by 2015 . Thus, it has substituted what should be a right for children with a goal that may or may not be attained a decade from now. That consensus has slanted attention toward the poorest and/or most indebted countries as global educational strategies became intertwined with development finance and/or debt relief. These are not rights-based,,$^{43}$ and, moreover,

41. Where the most widely used education indicator, school enrollment, shows that many, if not the majority of, school-age children have not even enrolled, the key follow-up question from the human rights perspective should be to ask whether this is because there simply are not enough schools or whether the schools exist but remain unaffordable. UNITED NATIONs, ECONOMIC AND Social Council, Commission on Human Rights; Mission to the United States of America: Report by Special Rapporteur Katarina Tomasevski II 1 il 32-56, U.N. Doc. E/CN.4/1999/49 (1999).

42. The priority attached to poverty reduction in international development strategies and the associated funding after the turn of the millennium creates immediate and intuitive support for the supposition that poverty constitutes the biggest obstacle for educating all children. From the human rights perspective, it is much more important to review government priorities in resource allocation, from which one can determine, for example, "a general decline in budgetary allocations for education" in the least developed countries in the 1980 s and the consequent deterioration in education. UNCTAD Secretariat, The Least Developed Countries 56 (1990). A closely related question is the identification of budgetary priorities, then and now, so as to discern whether educational allocations have diminished because of debt repayments or, for example, military expenditure. Tomasevski, supra note 10, at 9-15, 133-36 (2003).

43. Global education strategies promoted universal primary education in line with the requirements of international human rights law during the early post-war decades. EFA emerged in 1990 and the language shifted from primary to basic education at the 1990 Jomtien Conference. See Final Report of the World Conference on Education for All: Meeting Basic Learning Needs (Mar. 5-9, 1990). The Jomtien Conference was convened against the diminishing coverage of primary education in the 1980s, especially in Africa, and the reduced government capacity to halt further retrogression. It was a historic event intended to enhance priority for basic education through a 
have more influence than international human rights law in molding education. The reason for this is that compliance with international human rights law does not lead to increased international development finance. Conversely, compliance with the conditions for debt relief does, although the human rights obligations of the indebted governments may be undermined, if not abrogated, as a consequence. All global human rights treaties that deal with education require compulsory education to be free. ${ }^{44}$ The term "free" comprises direct, indirect, and opportunity costs; governments should eliminate all those costs that preclude children from completing the schooling that has been defined as compulsory, so as to keep children at school at least until they reach the minimum age for em-

global mobilization around time-bound targets. Id. The 1990 Jomtien Declaration did not include a requirement for primary education to be free and compulsory. Article 7 of the Jomtien Declaration stated that providing basic education for all was "the unique obligation" of national, regional, and local authorities, but immediately added that the authorities could not be expected to carry out that obligation alone. Therefore, it would be necessary to form partnerships with families, religious groups, local communities, and nongovernmental organizations as well as the private sector. World Declar. on Educ. for All, art. 7, cl. 1-2. Also, it used terms such as "access to education," id. at art. $3, \S 5, \mathrm{cl}$. 1-2, or "meet basic learning needs," id. at pmbl., instead of the right to education. Since the Jomtien Declaration was adopted less than one year after the Convention on the Rights of the Child, the two divergent approaches impeded a uniform, rights-based global education strategy. The Fourth Global Meeting of the International Consultative Forum on Education for All took place in Dakar on April 26-28, 2000 and adopted the Framework for Action. UNESCO, The Dakar Framework for Action-Education for All: Meeting Our Collective Commitments (France 2000). It was based on the acknowledgment that the commitments made at Jomtien in 1990 had not been met. The Dakar Framework for Action posited a "human right to benefit from an education that will meet" one's learning needs. Id. at 8 . However, World Bank's statement at the World Education Forum referred to free primary education as a long-term plan for the year 2015. James D. Wolfensohn, A Time for Action: Placing Education at the Core of Development, Presentation at the World Education Forum, Apr. 27, 2000, available at http:/www.unesco.org/ education/efa/wef_2000/speeches/wolfen.shtml (World Bank President, James Wolfensohn, supported the "call that by the year 2015 free education be a right for all children up to age 15."). A reference in World Bank's Education Strategy to the commitments by "155 nations and 150 NGOs" obfuscated the role of the states, which, unlike nongovernmental organizations, have human rights obligations. The Worlo Bank: Education Sector Strategy 7 (1999).

44. See International Covenant on Civil and Political Rights, opened for signature Dec. 19, 1966, 999 U.N.T.S. 171 (entered into force in 1976 and ratified thus far by 149 states); International Covenant on Economic, Social and Cultural Rights, opened for signature Dec. 16, 1966, art. 13, 993 U.N.T.S. 3, 8 (entered into force in 1976); International Convention on the Elimination of All Forms of Racial Discrimination, opened for signature Mar. 7, 1966, art. 5, 660 U.N.T.S. 211, 222 (entered into force in 1969); Convention on the Elimination of All Forms of Discrimination against Women, opened for signature Dec. 18, 1979, art. 10, 1249 U.N.T.S. 13, 17-18 (entered into force in 1981); Convention on the Rights of the Child, opened for signature Nov. 20, 1989, art. 28, 1577 U.N.T.S. 43, 53 (entered into force in 1990). 
ployment. ${ }^{45}$ The underlying logic is that elimination of financial obstacles makes it possible to reach all children. As long as families cannot afford education, compulsion cannot be enforced. As a consequence, children are deprived of education, and countries are deprived of educated and skilled populations.

When the core global human rights standards mandating primary education to be free and compulsory were adopted, there was full global consensus behind them. Enrollments rapidly expanded in the early decades only to halt because of economic crises and diminished public funding. The 1980s marked diminished public funding for education, accompanied by the introduction of user fees in primary education, especially in Africa. Global design of education became bifurcated, with international financial institutions requiring countries to charge fees for compulsory schooling as a condition of development finance, thereby contradicting the legal requirement that at least primary education should be free. ${ }^{46}$

The World Bank exemplifies a non-rights-based approach to education. ${ }^{47}$ The period from 1980 to 1995 marked an explicit rupture of the previous, and later, global consensus that primary education should be free. In the early 1980s, the Malawi

45. The interpretation of "free" tends to create more heat than light. International human rights law requires the elimination of direct charges, because these would preclude primary schooling for all those unable to pay them, making the attainment of compulsory education impossible. The obligation of parents to ensure the education of their children is meaningless if parents cannot afford the cost of education, and children are legally prohibited from working and cannot pay the cost of their schooling. The law cannot oblige either parents or governments to ensure free and compulsory education for all children if it is beyond their means. International human rights law mandates progressive realization of the right to education. This necessitates provision of free education as soon as possible. The corollary of the universality of the right to education is the universality of corresponding human rights obligations, which pertain to governments, both individually and collectively.

46. Authors have described the chronology of early post-war decades regarding the right to education and the global strategies of the time as well as the changes in the past three decades. See, e.g., Tomasevski, supra note 10, at 36-107 (discussing the promise of the 1948 Universal Declaration of Human Rights).

47. See United Nations, Economic and Social Council, Commission on Human Rights; Progress Report of the Special Rapporteur on the Right to Education, Katarina Tomasevski, Submitted in Accordance with Commission on Human Rights Resolution 1999/ 25 II 45-55, U.N. Doc. E/CN.4/2000/6 (2000); United Nations, Economic and Social Council, Commission on Human Rights-Economic, Social and Cultural Rights; Progress Report of the Special Rapporteur on the Right to Education-Katarina Tomasevski-Submitted in Accordance with Commission on Human Rights Resolution 2000/9 II II 31-41, U.N. Doc. E/ CN.4/2001/52 (2001). 
government increased school fees following a World Bank report, which indicated that an increase in secondary school fees might free government revenue. ${ }^{48}$ At the time, the World Bank was endorsing "judicious use of modest fees" with the justification that they would increase accountability. ${ }^{49}$ In 1990 , noting that cost sharing was more appropriate in post-primary education, the World Bank nevertheless hailed significant sums raised by direct charges in primary education. ${ }^{50}$

In 1992, the World Bank's commitment to sustaining and enhancing social expenditure, especially for primary education, ${ }^{51}$ was a signpost of change, leading to its opposition to for-fee primary schooling a decade later. The World Bank's 1999 education strategy affirmed that many states recognized the right to education, ${ }^{52}$ while the World Bank does not. Its frequent line of argument was that payments for public schooling by non-poor beneficiaries facilitated the targeting of government funding toward the poor. In September 2001, a non-binding statement announced that the World Bank "does not support user fees for primary education." 53 The text continued, "[W]here governments do levy user fees, the Bank helps to reduce the burden on poor people by recommending, and providing finance for targeted subsidies." 54 That statement kept direct charges imposed on public schooling by local communities, as different from the central government, implicitly endorsed. Such charges often result from the inability, or unwillingness, of the central government to finance public schools, which leads to "informal charges to parents and other fund-raising initiatives at the school level in supplementing public funding." ${ }^{25}$

48. George Psacharopoulos \& Maurefn Woodhall, Education for Development: AN Analysis of Investment Choices 150 (1985).

49. The World Bank, Education in Sub-Saharan Africa: Policies for Adjustment, Revitalization, and Expansion 53 (1988).

50. See The World Bank, Primary Education 44-45 (1990).

51. The World Bank's Adjustment Lending Policy, Operational Directive 8.60 of Dec. 21, 1992 specifies that explicit conditionality may be appropriate to enhance the poverty orientation of social expenditure and to sustain their levels.

52. See Ketleen Florestal \& Robb Cooper, Decentralization of Education: Legal Issues, at vii-viii (1997).

53. The World Bank, World Bank Issue Brief: User Fees in Health, Education, and Water, at http:/ web.worldbank.org/WBSITE/EXTERNAL/NEWS/0, contentMDK:20040982 menuPK:34480 pagePK:34370 theSitePK:4607,00.html (last updated Aug. 2003).

54. Id.

55. Gillian Perkins \& Ruslan Yemtsov, Armenia: Restructuring to Sustain Universal General Education 11, World Bank Technical Paper No. 498 (2001). 
The World Bank's shift toward opposing direct charges in public primary schooling has facilitated the revitalization of the previous global consensus that at least primary education should be free. Nevertheless, its precise scope depends on identifying all those charges which should be eliminated, and supplementing the correspondingly diminished income of schools with public funds.

A brief summary of the pattern of direct charges in public primary education illustrates the road traveled thus far. After twenty-one countries had been identified as imposing direct charges in public primary education in $1986,{ }^{56}$ there was a long silence about the incidence and prevalence of such charges. In 2002, the World Bank's in-house review of charging fees for primary education revealed that this practice was much more widespread than had been assumed. Direct charges in public primary schooling proved to be the norm rather than the exception. They were found in seventy-seven of the seventy-nine countries surveyed, and other "financial contributions" were required in sixty countries. ${ }^{57}$ That review covered only 79 out of 145 countries where the World Bank was involved, or could become involved, in education. ${ }^{58}$ The definition of "fees" included the cost of school uniforms or textbooks but not transportation or school meals, although all these constitute costs that have to be paid by families, unless they are subsidized by government. That in-house survey provided a welcome

56. A list of 21 countries with direct charges in primary education was published by the World Bank in 1986, but no information was provided as to which year that information referred. These countries were Bolivia, Burkina Faso, Central African Republic, Chile, Costa Rica, Haiti, India, Kenya, Korea, Lesotho, Malawi, Malaysia, Nigeria, Pakistan, Paraguay, Sierra Leone, Swaziland, Togo, Uganda, Uruguay, and Zambia. See George Psacharopulous et al., Financing Education in Developing Countries: An Exploration of Policy Options 55 (1986).

57. Tuition and other fees, or various financial contributions, were found in Armenia, Azerbaijan, Bangladesh, Benin, Bhutan, Bolivia, Bosnia and Herzegovina, Brazil, Bulgaria, Burkina Faso, Cambodia, Cameroon, Cape Verde, Chad, China, Colombia, Comoros, Dominican Republic, Eritrea, Ethiopia, Gambia, Ghana, Guatemala, Guinea-Bissau, India, Indonesia, Laos, Latvia, Lesotho, Madagascar, Malawi, Malaysia, Mali, Mauritania, Mauritius, Mexico, Moldova, Mozambique, Nepal, Nicaragua, Niger, Nigeria, Pakistan, Papua New Guinea, Paraguay, Peru, Philippines, Romania, Russia, Rwanda, Senegal, Solomon Islands, Tajikistan, Tanzania, Togo, Trinidad and Tobago, Turkey, Uganda, Vietnam, and Zambia.

58. That in-house survey relied on responses by the World Bank's education task team leaders and did not encompass those countries for which no response was obtained. Thus, a non-representative sample of 79 countries was analyzed out of "a total universe of some 145 countries," in the words of the authors. Raja Bentaouet Kattan \& Nicholas Burnett, User Fees in Primary Education 9 , available at http://www-wds.worldbank.org/servlet/WDSContentServer/WDSP/1B/2004/10/05/ 000012009_20041005102026/Rendered/PDF/301080PAPER0ERAcaseluserfees.pdf (last visited Jan. 26, 2005). 
breach of silence regarding the effects of the World Bank's alternating approaches to direct charges in the countries where its policies-or the lack thereof-carry considerable weight.

Furthermore, fees, contributions, and other direct charges were found in those countries whose international legal obligations and constitutional guarantees required primary education to be free. This phenomenon was highlighted by the authors of the in-house survey as an explanation for the paucity of data.

Very few countries compile data on the contributions of fees more generally to the public sector, even when the fees are commonplace, often because these fees may be formally unconstitutional, as in the Middle East and North Africa, or because they may be technically illegal, as in most of the CIS (Commonwealth of Independent States) countries. ${ }^{59}$

The fact that for-fee replaced free education, in violation of international and domestic law, raises key questions about the rule of law in education and in the work of the World Bank. This issue is fundamental for forging a global consensus on free education because it reveals that the World Bank's non-rightsbased approach results in violations of legal requirements that education should be free. The terms "formally unconstitutional" or "technically illegal," as used in the World Bank's in-house review, point to the necessity of upholding the rule of law. The next section turns to the lack of effective pressure toward knowing and upholding the law at the cross section between education and development finance. This gap is epitomized in the disconnect between legal requirements and public policies with respect to free public education in developing and transitional countries evidenced in the pattern of direct charges in public education, which the law mandates to be free.

\section{The Impact of Changes Within and Outside Law: Direct Charges in Public Primary Schooling in Developing and Transitional Countries}

The pledge of the World Education Forum in Dakar in 2000 that "no countries seriously committed to education for all will be thwarted in their achieve-

59. Id. 
ment of this goal by a lack of resources ${ }^{160}$ has not materialized. Aid for education remains minuscule. ${ }^{61}$ Insufficient funding impedes free education for all schoolage children, specifically in those countries where it is indispensable to overcome widespread poverty-based exclusion from education. ${ }^{62}$ Insufficient resources are routinely emphasized in government reports required by human rights treaties as the key obstacle to making education free. Although international cooperation has been anticipated in international human rights law to underpin the right to education, global education and development finance strategies have proved an obstacle to it.

Central governments routinely identify financial obstacles that should be eliminated in order to universalize primary education in their reports required by human rights treaties and in poverty reduction strategy papers (PRSPs). ${ }^{63} \mathrm{Be}$ cause in many countries it is the local—rather than the central-government that bears the principal financial responsibility for financing primary education, any human rights analysis ought to encompass local communities and extend to families, as well as to children without parental support, be they street children or AIDS orphans. The information available under human rights reporting

60. UNESCO, The Dakar Framework for Action 9 (2000), available at http://unesdoc. unesco.org/images/0012/001211/121147e.pdf (Ulrika Peppler Barry ed.) (adopted by the World Education Forum, Dakar, Senegal, Apr. 26-28, 2000).

61. The Global Campaign for Education pointed out in September 2003 that the World Bank's allocations to education amounted to $\$ 1.45$ billion, and would have to increase by an annual $\$ 4$ billion to meet the needs of those poor and highly indebted countries whose educational strategies were assessed as "sound" by the creditors and donors. See Global Campaign for Education, supra note 29.

62. The EFA Monitoring Report 2003/4 noted that the distribution of aid for education did not follow the logic of the greatest needs, and the Arab States, Central Asia, and Latin America received much more education aid per capita than South and West Asia. However, it noted that better-performing education systems tended to attract more aid, with the amount of aid per outof-school child increasing with the level of net enrollment. See Gender and Education for All, The Leap to Equality, supra note 14, at 241-45.

63. See United Nations, Economic and Social Council, Commission on Human Rights; Report Submitted by Katarina Tomasevski, Special Rapporteur on the Right to Education: Mission to Uganda - Addendum, U.N. Doc. E/CN.4/2000/6/Add.1 (1999) (noting that the "objectives of the visit were to assess the realization of the right to education, especially experiences with universal primary education ... in reducing financial obstacles impeding access to school."). PRSPs were introduced as a requirement for debt relief under the HIPC (Heavily Indebted Poor Countries Debt Relief Initiative). The first country to qualify, as well as to allocate a considerable part of debt relief and additional development finance to the elimination of direct charges in public primary education, was Uganda. 
procedures, PRSPs, and government reports within the Education for All (EFA) reporting system were the major sources of information for the list of countries where fees are charged in primary education (Table 2), and further details are available in regional overviews, which follow. As Table 2 shows, the incidences of direct charges are particularly widespread in Africa, both because of the continent's poverty and the influence of global debt relief and/or development finance strategy created by the merger between poverty and indebtedness.

Direct charges impose upon parents the obligation to finance the education of their children in public schools. Children of parents who cannot afford the costs and those without parents are victimized by being denied schooling. Moreover, many children have to work to pay the costs of their own primary schooling. ${ }^{64}$ The duty to financially contribute to the cost of primary education is spread among the whole population where education is financed by the state out of general taxation. Taxation exempts the poorest; those who do not earn enough to be liable for taxation are not taxed. Where charges are imposed in public primary schooling, those who are too poor to afford the cost are often not exempt from charges. Where exemptions are nominally provided, they are routinely too cumbersome or too humiliating to comply with or else too expensive to administer.$^{65}$ Furthermore, such charges have obliterated the boundary between public and private education by conditioning access to public education on purchasing power.

As the country-by-country surveys in this text show, these direct charges are known by a variety of names because in most countries they should not be-but

64. The linkage between child labor and the absence of schooling is well established. The ILO found that in the poorest region--Africa-29\% of children ages 5 to 14 work, while globally only $10 \%$ of child workers also attend school. Report of THe Director-General, International Labour Office, Working Out of Poverty 22-23 (2003). Nonetheless, strategies that tackle both child labor and school non-attendance are rare. One of the best known exceptions is the Brazilian Bolsa-Escola program, which originated from the need to combat child labor while preventing it in the future by offering free education to children to improve their chances in life. The beneficiaries are children of poor families, who would not be able to afford to go to school without BolsaEscola, that is, the monthly subsidy paid to the family as long as children regularly attend school. Marcelo Aguiar \& Carlos Enrique Araujo, Bolsa-Escola: Education to Confront Poverty (UNESCO 2002).

65. An initial survey of various fees charged in public primary education in 1999 on the basis of government reports under human rights treaties revealed a variety of fees (for enrollment, tuition, examinations, sports equipment, excursions, transportation, school meals, etc.), but no information about the financial costs of the collection and administration of these fees, or the procedures used where exemptions were anticipated for those who were too poor to pay the fees. UNITED NAtions, Economic and Social Council, Commission on Human Rights; Report by Special Rapporteur Katarina Tomasevski IIf51-54, U.N. Doc. E/CN.4/2000/6 (2000). 
Table 2: Countries with direct charges in public primary education by region

\begin{tabular}{|c|c|c|c|c|}
\hline Africa & Asia & $\begin{array}{l}\text { Eastern Europe } \\
\text { and Central Asia }\end{array}$ & $\begin{array}{l}\text { South America } \\
\text { and the Caribbean }\end{array}$ & $\begin{array}{l}\text { Middle East and } \\
\text { North Africa }\end{array}$ \\
\hline $\begin{array}{l}\text { Angola } \\
\text { Benin } \\
\text { Burkina Faso } \\
\text { Burundi } \\
\text { Cameroon } \\
\text { Central Afr. Rep. } \\
\text { Chad } \\
\text { Cōte d'Ivoire } \\
\text { Congo D.R. } \\
\text { Equat. Guinea } \\
\text { Eritrea } \\
\text { Ethiopia } \\
\text { Gabon } \\
\text { Gambia } \\
\text { Ghana } \\
\text { Guinea } \\
\text { Guinea-Bissau } \\
\text { Kenya } \\
\text { Lesotho } \\
\text { Liberia } \\
\text { Madagascar } \\
\text { Mali } \\
\text { Mauritania } \\
\text { Mozambique } \\
\text { Namibia } \\
\text { Niger } \\
\text { Nigeria } \\
\text { Rwanda } \\
\text { Senegal } \\
\text { Sierra Leone } \\
\text { South Africa } \\
\text { Sudan } \\
\text { Swaziland } \\
\text { Tanzania } \\
\text { Togo } \\
\text { Uganda } \\
\text { Zambia } \\
\text { Zimbabwe }\end{array}$ & $\begin{array}{l}\text { Bangladesh } \\
\text { Bhutan } \\
\text { Cambodia } \\
\text { China } \\
\text { Fiji } \\
\text { India } \\
\text { Indonesia } \\
\text { Laos } \\
\text { Malaysia } \\
\text { Maldives } \\
\text { Mongolia } \\
\text { Myanmar } \\
\text { Nepal } \\
\text { Pakistan } \\
\text { Papua NG } \\
\text { Philippines } \\
\text { Singapore } \\
\text { Vanuatu } \\
\text { Viet Nam }\end{array}$ & $\begin{array}{l}\text { Armenia } \\
\text { Azerbaijan } \\
\text { Bosnia/Herzegovina } \\
\text { Bulgaria } \\
\text { Georgia } \\
\text { Kyrgyzstan } \\
\text { Macedonia } \\
\text { Moldova } \\
\text { Russia } \\
\text { Serbia/ Montenegro } \\
\text { Tajikistan } \\
\text { Turkey } \\
\text { Ukraine } \\
\text { Uzbekistan }\end{array}$ & $\begin{array}{l}\text { Colombia } \\
\text { Ecuador } \\
\text { Grenada } \\
\text { Haiti } \\
\text { Jamaica } \\
\text { Nicaragua } \\
\text { Paraguay } \\
\text { Peru } \\
\text { St Lucia } \\
\text { St Vincent } \\
\text { Suriname } \\
\text { Trinidad \& Tobago }\end{array}$ & $\begin{array}{l}\text { Djibouti } \\
\text { Egypt } \\
\text { Israel } \\
\text { Lebanon } \\
\text { Qatar } \\
\text { Sudan } \\
\text { UA Emirates } \\
\text { Yemen }\end{array}$ \\
\hline
\end{tabular}

are-charged. Numerous and diverse fees are charged for enrollment, tuition, and examinations. ${ }^{66}$ Where tuition is free, charges are levied for the use of educational facilities and materials (such as laboratories, computers, or sports equipment), or for extracurricular activities (such as excursions or sports), or generally

66. In Beijing, for example, the Education Committee has reportedly approved no less than 14 different kinds of school fees, even though public compulsory education should be free according to China's own legislation. United Nations, Economic and Social Council, Commission on Human Rights; The Right to Education, Report Submitted by the Special Rapporteur, Katarina Tomasevski: Mission to China fl 13, U.N. Doc. E/CN.4/2004/45/Add.1 (2003). 
for supplementing teachers' salaries, or financing school maintenance. Such fees represent a considerable burden because they are added to other costs of education. Such direct expenditures include textbooks (which are provided free of charge in some countries, subsidized in many, but sold at a profit in others), supplies and equipment (notebooks, sketchbooks, pens, and pencils), transportation (provided free of charge in few countries), meals (also provided free of charge in some countries, sometimes as an inducement for parents to send their children to school), as well as school uniforms where these are required for school attendance or represent a custom whose breach would penalize children without uniforms. These costs can be prohibitively high and prevent children from enrolling or force them to drop out before completing primary school. ${ }^{67}$

The pattern of the charges shows that they are poverty-driven. No direct charges in public compulsory education have been reported from thirty-four members of the European Union (EU), the European Economic Area, and the Organisation for Economic Co-operation and Development (OECD) by their respective governments, with only two exceptions. ${ }^{68}$ As Table 2 shows, charging of school fees encompasses ninety-two countries and is most particularly widespread in Africa, followed by Asia. Government reports required by human rights treaties, from which most of the data originate, routinely refer to their inability to introduce or restore free education for all children of compulsory

67. The World Bank has found that "the children in any country that are currently out of school are those the least able to contribute to the cost of education." Achieving Universal Primary Education by 2015: A Chance for Every Child 81 (Barbara Bruns et al. eds., 2003).

68. The countries are Australia, Austria, Belgium, Canada, Cyprus, the Czech Republic, Denmark, Estonia, Finland, France, Germany, Greece, Hungary, Iceland, Ireland, Italy, Japan, Latvia, Lithuania, Luxembourg, Malta, the Netherlands, New Zealand, Norway, Poland, Portugal, Republic of Korea, Slovakia, Slovenia, Spain, Sweden, Switzerland, the United Kingdom of Great Britain and Northern Ireland, and the United States. The two exceptions are the Netherlands and New Zealand. The Netherlands has reported that "[p]rimary education is free of charge. Some schools may require a parental contribution, but they may nọt refuse to admit a child whose parents cannot or will not pay." United Nations, Economic and Social Council; Implementation of the International Covenant on Economic, Social and Cultural Rights-Netherlands: European Part of the Kingdom-Addendum II 280, U.N. Doc. E/ 1990/6/Add.1 1 (1996). Similarly, New Zealand has reported that "[s]ome schools ask students to pay a specific amount as a 'school fee' to assist with the costs of the school activities and materials. Payment of this 'fee' is voluntary." United Nations, Convention on the Rights of the Child, Committee on the Rights of the Child; Consideration of Reports Submitted by States Parties Under Article 44 of the Convention - Initial Reports of States Parties Due in 1995Addendum: New Zealand II 277, U.N. Doc. CRC/C/28/Add.3 (1995). 
school age. Related references in government reports to structural adjustment programs, creditor conditions, and/or donor conditions demonstrate the discord between rights-based and non-rights-based global educational strategies. Rather than facilitating the realization of the right to education, global policies often impede it.

\section{A. Sub-Saharan Africa}

A letter to the editor of the New African from Zimbabwe described how primary schools must "increase[] their fees every six weeks just to cope with inflation." ${ }^{69}$ This confirmed the finding of the Committee on the Rights of the Child in 1996 that "primary education is neither free nor compulsory." ${ }^{70}$ Zimbabwe became unrecognizable from the country whose commitment to education and independence had once been lauded. Direct charges in public primary education were abolished seven months after independence and

[T]he expansion of schools and the reduction in fees paved the way for virtually all of Zimbabwe's children to enroll in school. Indeed, by 1984 primary enrollments were approaching 100 percent of school age children, and by 1985 some 83 percent of primary students were continuing on to secondary school. ${ }^{71}$

In 2000 , the net enrollment in primary education diminished to 80 percent, ${ }^{72}$ and in secondary education it was halved to 40 percent. $^{73}$

Similar retrogression took place in other African countries. Reports by African governments required by human rights treaties have often highlighted

69. Letter from Cathy Buckle, Marondera, Zimbabwe, to New Afr. 4 (Jan. 2004).

70. United Nations, Convention on the Rights of the Child, Committee on the Rights of the Child; Consideration of Reports Submitted by States Parties Under Article 44 of the Convention - Concluding Observations of the Committee on the Rights of the ChildAddendum: Zimbabwe II 19, U.N. Doc. CRC/C/15/Add.55 (1996).

71. John Pape, Changing Education for Majority Rule in Zimbabwe and South Africa, 42 CoMP. Educ. Rev. 253, 257 (1998) (citations omitted).

72. See Gender and Education for All: The Leap to Equality, supra note 14, at 335.

73. Id. at 351 . 
structural adjustment programs as the obstacle to free education. ${ }^{74}$ They have also emphasized that education is dependent on foreign funding and, thus, on the conditions attached to that funding by creditors or donors. ${ }^{75}$ In the 1980 s, reductions of education budgets and the imposition of direct charges upon families in countries that had previously been committed to free primary education resulted in decreased enrollments and increased illiteracy. ${ }^{76}$ In 2002, Tanzania's Minister of Education described the shift from free to for-fee education, before Tanzania reverted back to free education:

74. See United Nations, Convention on the Rights of the Child, Committee on the Rights of the Child; Consideration of Reports Submitted by States Parties Under Article 44 of The Convention-Concluding Observations-Addendum: Benin fl 11, U.N. Doc. CRC/C/15/ Add.106 (1999); United Nations, Convention on the Rights of the Child, Committee on the Rights of the Child; Consideration of Reports Submitted by States Parties Under Article 44 of the Convention - Initial Reports of States Parties Due in 1995-Addendum: Cameroon 1 203, U.N. Doc. CRC/C/28/Add.16 (2001); Ghana Ministry of Educ., The Development of Education 1994-1996: National Report from Ghana by the Ministry of Education, April 1996, available at http:// www.ibe.unesco.org/International/Databanks/Dossiers/rghana.htm; United Nations InTERNAtional Convention on the Elimination of All Forms of Racial Discrimination, Committee on the Elimination of Racial Discrimination; Consideration of Reports Submitted by States Parties Under Article 9 of the Convention-Fourteenth Periodic Reports of States Parties Due in 2001-Addendum: Mali I 129, U.N. Doc. CERD/C/407/Add.2 (2002).

75. See United Nations, Convention on the Rights of the Child, Committee on the Rights of the Child; Consideration of Reports Submitted by States Parties Under Article 44 of the Convention - Fourteenth Periodic Reports of States Parties Due in 2001 - AdDENDUM: MALI If 68, U.N. Doc. CRC/C/11/Add.18 (1998) (stating that education in the Central African Republic, "for the most part, depends on international assistance."); see also UNITED NAtions, Convention on the Rights of the Child, Committee on the Rights of the Child; Consideration of Reports Submitted by States Parties Under Article 44 of the ConventionInitial Reports of States Parties Due in 1993-Addendum: Côte d'lvoire II 83, U.N. Doc. CRC/C/8/Add.4I (2000) (noting the support of the African Development Bank, UNICEF, and NGOs for Côte d'Ivoire's education system); United Nations, Convention on the Rights of the Child, Committee on the Rights of the Child; Consideration of Reports Submitted by States Parties Under Article 44 of the Convention - Initial Reports of States Parties Due in 1992-Addendum: Guinea-Bissau 1 216, U.N. Doc. CRC/C/3/Add.63 (2001) (emphasizing that $90 \%$ of the sector of education in Guinea Bissau relies on external support); UNited Nations, Convention on the Rights of the Child, Committee on the Rights of the Child; Consideration of Reports Submitted by States Parties Under Article 44 of the Convention-Initial Reports of States Parties Due in 1993-Addendum: Malawi 19 If 253-54, U.N. Doc. CRC/C/8/ Add.43 (2001) (Malawi has pointed out that it is not its law but "the Policy and Investment Framework (PIF) 1995-2000" that has guided education, and "[t]he PIF policies and strategies relate to access, equity and internal efficiency" as these are written for the World Bank's approval.).

76. See Tomasevski, supra note 10, at 69-77 (noting that the implementation of school fees resulted in a sharp decrease in enrollments). 
In the 1980s under the dynamic leadership of the founding father of our nation Mwalimu (Teacher) Julius Kambarage Nyerere with donor funding we had achieved near universal primary education (UPE) reaching peaks of NER [net enrolment ratio] of $93 \%$ and GER of $98 \%$ in 1980. Inadequate economic growth and donor driven notions of cost-sharing, cost-recovery and user-charges led to introduction of primary school fees. After introduction of school fees enrolment started to decline and reached bottom low of NER ... 57\% and GER (gross enrolment ratio) $77 \%$ in 2000.77

The pattern of direct charges in public primary education is presented in Table 3. Out of forty-five countries, only three-Botswana, ${ }^{78}$ Mauritius,${ }^{79}$ and Seychelles ${ }^{80}$-guarantee free primary education to all children. As Table 3

77. Joseph Mungai, Minister for Education and Culture, United Republic of Tanzania, Sector Based Educational Development Funding: Strengths and Weaknesses as Seen from a Partner Country, . May 2002.

78. See United Nations International Convention on the Elimination of All Forms of Racial Discrimination, Committee on the Elimination of Racial Discrimination; Reports Submitted by States Parties Under Article 9 of the Convention-Fourteenth Periodic Reports of States Parties Due in 2001-Addendum: Botswana If 36(e), U.N. Doc. CERD/C/407/ Add.1 (2002) ("Botswana provides free primary, secondary and technical education and to some extent free university education to all its children.").

79. United Nations, Economic and Social Council; Substantive Session-Initial Reports Submitted by States Parties Under Articles 16 and 17 of the Covenant-Addendum: Mauritrus 1 338, U.N. Doc. E/1990/5/Add.21 (1994) (The Mauritius “government is discharging its obligation to provide primary education that is compulsory and available free to all by providing all primary school children with a midday snack as an incentive to regular attendance." The government is also "ensuring that each village council area has at least one primary school, i.e. the primary schools are within walking distance for all pupils.") [hereinafter Initial Report: Mauritius]; see also United Nations, Convention on the Rights of the Child, Committee on the Rights of the Child; Consideration of Reports Submitted by States Parties Under Article 44 of the Convention - Initial Reports of States Parties Due in 1992: Mauritius If 4, U.N. Doc. CRC/C/3/ Add.36 (1995) ("[P] rimary and secondary education were made free since 1977, which implied that children from 5 to 18 have free access to education."). [hereinafter Initial Reports: Mauritius]

80. In Seychelles, "education is free to all students and is compulsory for all children up to the age of 16." United Nations, Convention on the Rights of the Child, Committee on the Rights of the Child; Consideration of Reports Submitted by States Parties Under Article 33 of the Convention-Initial reports of States parties due in 1995-Addendum: Seychelles $\$$ 359, U.N. Doc. CRC/C/3/Add.64 (2002).

Having achieved equal access and full enrolment during the compulsory schooling years the goals now encompass being able to afford a quality education... The Ministry of Education ensures that school activities which are undertaken during the 
shows, direct charges have become prevalent, although a number of governments have made a commitment to eliminate such charges. Table 3 also shows that legal guarantees of free education are often belied by direct charges for education.

Government obligation to ensure the right to education can be facilitated or hampered through international cooperation. Legal guarantees of free education should-but often do not--guide policies and practices of individual governments and governments acting collectively, which include governments acting through international donor and creditor institutions. Zambia is an example of a country with an absence of a legal guarantee of free education. The government stated in 2002 that "there is no legislation that guarantees the right to education[,]" education; parents [and] communities will be asked to contribute to the education[al] cost of their children in the form of user fees." ${ }^{22}$ Thus, a child can be excluded from school for failing to pay the demanded charges, even if the parents are unable to pay them. ${ }^{83}$ The World Bank has reached the obvious conclusion: "There is growing evidence that widespread poverty is reducing parental ability to pay school-related costs." ${ }^{\prime 4}$

In Table 3, countries where there is a guarantee of free education are marked with a "yes." "No" is used where such a guarantee is absent, and "prog." stands for a commitment to progressive realization, meaning the introduction and broadening of free, all-encompassing, and compulsory education as circumstances permit.

school day are provided free of charge and that resources are made available to subsidize those children who cannot afford to undertake out-of-school activities, for example music and dance.

Id. at II 374,377 .

81. United Nations, Convention on the Rights of the Child, Committee on the Rights of the Child; Consideration of Reports Submitted by States Parties Under Article 44 of the Convention-Initial Reports of States Parties Due in 1994-Addendum: Zambia Il 329, U.N. Doc. CRC/C/11/Add.25 (2002).

82. Ministry of Education, Lusaka, The Development of Education 1994-1996: A National Report of Zambia, Feb. 1996.

83. See Initial. Reports: Mauritius, supra note 79, at II 442, 482.

84. The World Bank, Programme Appraisal Document on a Proposed Credit in the Amount of SDR 28.5 Million (US\$40Million Equivalent) to the Republic of Zambia in Support of the First Phase of the Basic Education Subsector Investment Program 5 (Mar. 5, 1999), available at http:/wwwwds.worldbank.org/servlet/WDS_IBank_Servlet? pcont $=$ details\&eid $=000094946 \_99032505570044$ (last visited Feb. 3, 2005). 
Table 3: Sub-Saharan Africa

\begin{tabular}{|c|c|c|c|c|c|}
\hline \multirow[t]{2}{*}{ Country } & \multicolumn{3}{|c|}{$\begin{array}{l}\text { Legal guarantee } \\
\text { of free education }\end{array}$} & \multicolumn{2}{|c|}{ School fees charged } \\
\hline & Yes & No & Prog. & Yes & No \\
\hline Angola & & 4 & & $\sqrt{ }$ & \\
\hline Benin & & & $\sqrt{ }$ & $\sqrt{ }$ & \\
\hline Botswana & $\checkmark$ & & & & $\sqrt{1}$ \\
\hline Burkina Faso & & & $\sqrt{ }$ & $\sqrt{ }$ & \\
\hline Burundi & & $\sqrt{1}$ & & $\sqrt{ }$ & \\
\hline Cameroon & & $\sqrt{1}$ & & & $\sqrt{ }$ \\
\hline Cape Verde & & $\sqrt{ }$ & & $\sqrt{ }$ & \\
\hline Central African Republic & & $\sqrt{ }$ & & $\sqrt{ }$ & \\
\hline Chad & $\sqrt{ }$ & & & $\sqrt{ }$ & \\
\hline Comoros & & $\sqrt{1}$ & & $\sqrt{ }$ & \\
\hline Cóte d'Ivoire & & $\sqrt{ }$ & & $\checkmark$ & \\
\hline Congo & $\sqrt{1}$ & & & T & \\
\hline Congo D.R. & $\sqrt{ }$ & & & $\sqrt{ }$ & \\
\hline Equatorial Guinea & $\sqrt{ }$ & & & $\sqrt{ }$ & \\
\hline Eritrea & & & $\sqrt{ }$ & $\sqrt{ }$ & \\
\hline Ethiopia & & $\sqrt{1}$ & & $\sqrt{ }$ & \\
\hline Gabon & $\sqrt{ }$ & & & $\sqrt{ }$ & \\
\hline Gambia & $\sqrt{ }$ & & & $\sqrt{ }$ & \\
\hline Ghana & $\sqrt{1}$ & & & $\sqrt{ }$ & \\
\hline Guinea & & $\sqrt{1}$ & & $\sqrt{ }$ & \\
\hline Guinea-Bissau & $\sqrt{ }$ & & & $\sqrt{ }$ & \\
\hline Kenya & $\sqrt{ }$ & & & 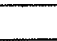 & $\sqrt{ }$ \\
\hline Lesotho & & & $\sqrt{ }$ & 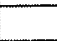 & $\sqrt{ }$ \\
\hline Liberia & & & $\sqrt{ }$ & $\sqrt{ }$ & \\
\hline Madagascar & $\sqrt{ }$ & & & $\sqrt{ }$ & \\
\hline Malawi & $\sqrt{ }$ & & & & $\sqrt{1}$ \\
\hline Mali & $\sqrt{ }$ & & & $\sqrt{ }$ & \\
\hline Mauritania & $\sqrt{ }$ & & & J & \\
\hline Mauritius & $\sqrt{ }$ & & & & $\sqrt{ }$ \\
\hline Mozambique & & $\sqrt{ }$ & & $\sqrt{ }$ & \\
\hline Namibia & $\sqrt{ }$ & & & $\sqrt{ }$ & \\
\hline Niger & $\sqrt{1}$ & & & $\sqrt{ }$ & \\
\hline Nigeria & $\sqrt{ }$ & & & & $\sqrt{ }$ \\
\hline Rwanda & $\sqrt{ }$ & & & $\sqrt{ }$ & \\
\hline Senegal & $\sqrt{1}$ & & & & $\sqrt{ }$ \\
\hline Seychelles & $\sqrt{1}$ & & & & $\sqrt{ }$ \\
\hline Sierra Leone & & $\sqrt{1}$ & & $\sqrt{ }$ & \\
\hline Somalia & & $\sqrt{5}$ & & $\sqrt{ }$ & \\
\hline South Africa & & $\sqrt{1}$ & & $\sqrt{ }$ & \\
\hline Swaziland & & $\sqrt{1}$ & & T & \\
\hline Tanzania & & $\sqrt{1}$ & & & $\sqrt{ }$ \\
\hline Togo & & & J & T & \\
\hline Uganda & & $\sqrt{1}$ & & & $\sqrt{1}$ \\
\hline Zambia & & $\sqrt{7}$ & & $\sqrt{ }$ & \\
\hline Zimbabwe & & 4 & & $\sqrt{ }$ & \\
\hline
\end{tabular}


Legal guarantees may be a reflection of government's commitment to the right to education, but they may also be a substitute for such a right. Moreover, a number of constitutions mention the right to education but do not specify its nature and scope, nor the corollary government obligations. ${ }^{85}$ These tend to be interpreted as guidance for government policy rather than specific obligations, which would ensue from legally enforceable rights. In Madagascar, "[t]he State is duty-bound to organize education that is public, free of charge and accessible to all." ${ }^{86}$ Without an effective mechanism to hold the government accountable for compliance with that duty, it is uncertain whether the government will comply with the duty. This demonstrates the need for an enforceable right to education in order to hold the government accountable for not complying with a duty it so readily acknowledges. The importance of clarity in constitutional guarantees of the right to education has been painfully visible in South Africa. The South African Constitution states that "[e]veryone has the right . . . to a basic education, including adult basic education; and ... to further education, which the state, through reasonable measures, must make progressively available and accessible." ${ }^{87}$ This provision is likely to await the Constitutional Court's explana-

85. The 1996 Constitution of Comoros belongs to that category since there is no definition of what the right to education means, as does the 1995 Constitution of Côte d'Ivoire. See UNITEd NAtions, Convention on the Rights of the Child, Committee on the Rights of the Child; Report on the Twenty-Fifth Session II 640, U.N. Doc. CRC/C/100 (2000); United Nations, Convention on the Rights of the Child, Committee on the Rights of the Child; Consideration of Reports Submitted by States Parties Under Article 44 of the Convention - Initial Reports of States Parties Due in 1993-Addendum: Côte d'Ivolre II 81 and 173, U.N. Doc. CRC/C/8/Add.41 (2000).

86. United Nations, Convention on the Rights of the Child, Committee on the Rights of the Child; Consideration of Reports Submitted by States Parties Pursuant to Article 44 of the Convention - Initial Reports of States Parties Due in 1993-Addendum: Madagascar 215, U.N. Doc. CRC/C/8/Add.5 (1993).

87. South African Const. ch. $2, \S 29$, pt. 1 . The South African government confirmed its interpretation that this constitutional guarantee meant that education was a fundamental right, but it did not claim that education should be free by including a "[p]rovision for the determination of fees by majority resolution of the parent body." United Nations, Convention on the Rights of the Child, Committee on the Rights of the Child; Consideration of Reports Submitted by States Parties Under Article 44 of the Convention - Initial Reports of States Parties Due in 1997-Addendum: South Africa II 399(f), U.N. Doc. CRC/C/51/Add.2 (1998). 
tion of what the provision actually means. In the meantime, primary education is not free..$^{88}$

A number of countries have constitutional guarantees that reflect the international human rights standards and state that primary and/or basic education should "be free, compulsory and available to all." ${ }^{89}$ The 1992 Constitution of Congo includes a guarantee of free instruction, but adds that "all instruction shall be placed under the surveillance and control of the State." 90 Such a partial guarantee is inconsistent with international human rights law in denying freedom of education. Moreover, its promise of free instruction has also not been translated into reality. The 1992 Constitution of Angola obliges the state only to "promote access to education"91 and thus does not promise either free or allencompassing primary education. Similarly, in Burundi, the constitution refers to "equal access to education" 92 rather than a right of each child against the state. This is also the case in Cameroon, ${ }^{93}$ while in the Central African Republic "children are guaranteed access to sources of knowledge, instruction, culture and vo-

88. See South African Human Rights Commission, Third Economic and Social Rights Report Executive Summary 81 (2001); see also United Nations, Convention on the Rights of the Child, Committee on the Rights of the Child; Report on the Twenty-Third Session II 447 , U.N. Doc. CRC/C/94 (2000) (noting that although the law provides for compulsory education between the ages of 7 and 15 years, primary education is not free).

89. See, e.g., United Nations, Convention on the Rights of the Child, Committee on the Rights of the Child; Consideration of Reports Submitted by States Parties Under Article 44 of the Convention - Initial Reports of States Parties Due in 1992-Addendum: Gambia I 176, U.N. Doc. CRC/C/3/Add.61 (2000); United Nations, International Convention on the Elimination of All. Forms of Racial Discrimination, Committee on the Elimination of Racial Discrimination; Reports Submitted by States Parties Under Article 9 of the Convention-Seventeenth Periodic Reports of States Parties Due in 2002-Adpendum: Ghana II 122(e), U.N. Doc. CERD/C/431/Add.3 (2002).

90. Republic of the Congo Const. title II, art. 37 (1992).

91. Angola Const. art 29, § 1 .

92. Burundi Const. title III, ch. 1, art. 34. See also United Nations, Convention on the Rights of the Child, Committee on the Rights of the Child; Consideration of Reports Submitted by States Parties Under Article 44 of the Convention-Initial Reports of States Parties Due in 1992 - Addendum: Burundi fl 55, U.N. Doc. CRC/C/3/Add.58 (1998).

93. Cameroon Const. pmbl. ("[T]he State shall guarantee the child's right to education. Primary education shall be compulsory."); see also United Nations, Convention on the Rights of the Child, Committee on the Rights of the Child; Consideration of Reports Submitted by States Parties Under Article 44 of the Convention-Initial Reports of States Parties Due in 1995-Adpendum: Cameroon 19 192-93, U.N. Doc. CRC/C/28/Add.16 (2001) (recognizing that legislation has interpreted this provision to mean "equality of opportunity for access to education."). 
cational training." ${ }^{94}$ The constitutions of Eritrea and Ethiopia lay down the identical formulation, whereby citizens have "the right to equal access to publicly funded social services." ${ }^{55}$ In Guinea-Bissau, the constitutional guarantee stipulates that "the State is responsible for the promotion of free and equal access of all citizens to different educational levels[,]" which would imply that education is free throughout public institutions at all levels of the educational pyramid. ${ }^{96}$ However, the addition of the right of children to attend "formal, private and cooperative schools" 1 indicates that "free and equal access" may not mean that schooling is free of charge. Cooperative or community schools have been established in many countries, and one of the underlying motives seems to have been to shift the financial responsibility for education from the government to the communities. ${ }^{98}$ The 1992 Constitution of Togo obliges the government to progressively ensure free public education, ${ }^{99}$ which was subsequently assessed as "relatively free." 100 At the turn of the millennium, to encourage schooling of girls, the government reduced tuition fees in public primary school. ${ }^{101}$

94. Cent. Afr. Rep. Const.; see also United Nations, Convention on the Rights of the Child, Committee on the Rights of the Child; Consideration of Reports Submitted by States Parties Under Article 44 of the Convention-Initial Reports of States Parties Due in 1994-Addendum: Central African Republic II 67, U.N. Doc. CRC/C/11/Add. 18 (1998).

95. Eritrea Const.; Ethiopia Const.; Although the constitutional formulas are identical, their interpretation is not. The government of Eritrea has claimed that it is "committed to making basic education free and compulsory," but nevertheless "the community and direct beneficiaries will be made to contribute varying amounts towards financing the cost of education." UNITED Nations, Convention on the Rights of the Child, Committee on the Rights of the Child; Consideration of Reports Submitted by States Parties Under Article 44 of the Convention - Initial Reports of States Parties Due in 1996-Addendum: Eritrea III 87, 302, U.N. Doc. CRC/C/41/ Add. 12 (2002). The government of Ethiopia introduced cost sharing mechanisms in 1994, in anticipation of the 1995 Constitution. Education Sector Strategy, Addis Ababa (Sept. 1994). This illustrates a common discrepancy between commitments presented simultaneously, by the same government, to international financial institutions and to those that bear "human rights" in their titles.

96. Guinea-Bissau Const. art. 49, 50.

97. Id.

98. Seegenerally Yolande Miller-Grandvaux \& Karla Yoder, A Literature Review of CommuNITY Schools in Africa (2002) (noting the important role that community schools play in the educational landscape in sub-Saharan Africa and the role that communities play in financing these schools).

99. République du Togo Const. art. 35 (1992).

100. Developpement de l'éducation: Rapport national du Togo par la Ministère de l'éducation nationale et de la recherche scientifique (June 1996).

101. United Nations, Economic and Social Council, Human Rights Committee; Consideration of Reports Submitted by States Parties Under Article 40 of the Covenant: Togo 1 84, U.N. Doc. CCPR/C/TGO/2001/3 (2001). 
The co-responsibility of parents and the government in paying for primary education is affirmed in the law of Cape Verde: "[T]he State, together with families, must bear the costs of compulsory education." 102 There is, however, no supplementary guarantee that the state will act in loco parentis for children who do not have parents to pay for their schooling and for those children whose parents simply cannot afford the cost. In Niger, the constitution is even more explicit and provides that "parents have the duty to educate children, with State support[,]"103 but subsequent legislation has clarified that it is "the obligation of the State to make primary education compulsory and free." 104

In Benin, the 1990 Constitution states that "primary education shall be compulsory" and "the State shall progressively ensure that public education is free of charge." 105 In contrast, Burkina Faso has constitutional and legal guarantees making education compulsory but not free. ${ }^{106}$ Effectively, education is not compulsory. In Guinea, the 1958 Constitution declared the right to education, but the subsequent laws on education specified that it should be compulsory, though no guarantee that it should also be free has been added. The right to education was defined in its political and civil dimensions only, allowing for private schools

102. United Nations, Convention on the Rights of the Child, Committee on the Rights of the Child; Consideration of Reports Submitted by States Parties Under Article 44 of the Convention-Periodic Reports Due in 1994-Addendum: Cape Verde I 149, U.N. Doc. CRC/ C/1 l/Add.23 (2001).

103. Niger Const.

104. United Nations, Convention on the Rights of the Child, Committee on the Rights of the Child; Consideration of Reports Submitted by States Parties Under Article 44 of the Convention-Initial Reports of States Parties Due in 1992-Addendum: Niger fl 273, U.N. Doc. CRC/C/3/Add.29/Rev.1 (2001); see also id. at II 274.

105. Benin Const.; United Nations, Economic and Social Council; Implementation of the International Covenant on Economic, Social and Cultural Rights-Initial. Reports Submitted by States Parties Under Articles 16 and 17 of the Covenant-Addendum: Benin II II 395-96, U.N. Doc. E/1990/5/Add.48 (2001).

106. Burk. Faso Const. ("Education is compulsory for all. This right is recognized to children in the law without distinction. ... Nevertheless, many children still do not enjoy the right to education, owing to a shortage of buildings and teaching staff, the poverty of parents and a lack of understanding of the importance of education."). United Nations, Convention on the Rights of the Child, Committee on the Rights of the Child; Consideration of Reports Submitted by States Parties Under Article 44 of the Convention-Initial Reports of States Parties Due in 1997-Addendum: Burkina Faso II 358, U.N. Doc. CRC/C/65/Add. 18 (2002); see also id. at II 515 ("Regrettably, some children who have access to school are expelled for poor performance or nonpayment of school fees despite the legal ban on expelling children before they reach the age of 16."). 
that the government should control. ${ }^{107}$ In Malawi, primary education was made free in 1994 through the abolition of school fees but it has not yet been made compulsory. ${ }^{108}$ The government of Mozambique stated in 2001 that "the introduction of compulsory schooling should be programmed gradually in line with available material and organizational capacity." 109

These varied constitutional and legal formulations point to the need to differentiate between the political will of individual governments to guarantee education as a right and their ability to translate this commitment into practice. However, assessing political will is as difficult as it is important. Promises regarding education have been made in political declarations, constitutions, and laws, and too many have been betrayed. Human rights law embodies the obligations of the state, which remain unaltered by changing governments. Nevertheless, there are frequent affirmations by governments themselves in their reports required by human rights treaties that their own practice violates the law. Thus, Mali has reported: "Whereas all Malian children have a legal right to attend schools, in actual fact the available school buildings and teachers are insufficient to cater for all children of school age." 110 The government of Senegal has re-

107. United Nations, Convention on the Rights of the Child, Committee on the Rights of the Child; Examination of Reports Presented by States Parties in Conformity with Article 44 of the Convention-Initial Reports Awaited From the States Parties for 1992-AdDENDUM If 140, U.N. Doc. CRC/C/3/Add.48 (1997). In support of the interpretation of "free" only in terms of parental choice of private schooling, an earlier Guinean report noted that "the principle of free primary education is guaranteed by law but is not always applied." UNited Nations, Economic and Social Council, Committee on Economic, Social and Cultural Rights; Consideration of Reports Submitted by States Parties Under Articles 16 and 17 of the Covenant-Concluding Observations of the Committee on Economic, Social and Cultural Rights-Addendum: Guinea, U.N. Doc. E/C.12/1/Add.5 (1996).

108. United Nations, Convention on the Rights of the Child, Committee on the Rights of the Child; Consideration of Reports Submitted by States Parties Under Article 44 of the Convention-Initial Reports of States Parties Due in 1993-Addendum: Malawi II 1 38, 67, U.N. Doc. CRC/C/8/Add. 43 (2001) (noting that the grant of primary education as a right falls short of the Constitutional obligation requiring primary education to be both compulsory and free).

109. United Nations, Convention on the Rights of the Child, Committee on the Rights of the Child; Consideration of Reports Submitted by States Parties Under Article 44 of the Convention-Initial Reports of States Parties Due in 1996-Adpendum: Mozambique I 396, U.N. Doc. CRC/C/41/Add.11 (2001).

110. United Nations, International Convention on the Elimination of All Forms of Racial Discrimination, Committee on the Elimination of Racial Discrimination; Consideration of Reports Submitted by States Parties Under Article 9 of the ConventionFourteenth Periodic Reports of States Parties Due in 2001-Addendum: Mali $\mathbb{I}$ 129, U.N. Doc. CERD/C/407/Add.2 (2002). 
ported that "from the pre-school level to university, public education is free of charge and received by all pupils and students subject to the availability of places." "II Such acknowledgements that the law does not guide the practice, but is marginalized by it, are disturbing because all law is potentially undermined if one of its segments is breached with impunity by the government that should be its guardian, and with full knowledge and tolerance of international organizations, which are all formally committed to respecting the law.

In Benin, both reports under human rights treaties and self-assessments within the EFA process confirm the direct charges in public primary education: "The parents of school children bear the cost of the furniture and educational materials used by their children and pay fees (droits d'écolage). Their contributions in the education sector also consist of various specific contributions (cotisations)." 112 The charging of school fees in primary education was confirmed in Benin's report required by the International Covenant on Economic, Social and Cultural Rights in 2001. ${ }^{113}$ The report acknowledged: "The obligation to attend school has been statutory since 1975 but has remained a pious hope."114 The reason has also been identified: "The successive structural adjustment programmes to which Benin has been subjected since 1989 have not yet enabled it to adopt a detailed plan for implementation of the principle of compulsory and free primary education for all." 115 Similarly, the government of Chad acknowledged in

111. United Nations, Economic and Social. Council; Implementation of the International Covenant on Economic, Social and Cultural Rights-Second Periodic Reports Submitted by States Parties Under Articles 16 and 17 of the Covenant in Accordance with the Programmes Established by Economic and Social Council Resolution 1988/4-Addendum: SENEGAL II 108, U.N. Doc. E/1990/6/Add.25 (2000).

112. République du Benin, Ministère de l'Éducation Centre Nationale et de la Recherche Scientifique: Education pour Tous, Bilan à l'an 2000, Rapport final (2000).

113. United Nations, Economic and Social Council; I mplementation of the International. Covenant on Economic, Social and Cultural Rights-Initial Reports Submitted by States Parties Under Articles 16 and 17 of the Covenant-Addendum: Benin 1 324, U.N. Doc. E/ 1990/5/Add.48 (2001).

114. United Nations, Convention on the Rights of the Child, Committee on the Rights of the Child; Consideration of Reports Submitted by States Parties Under Article 44 of the Convention of the Rights of the Child - Initial Reports of States Parties Due in 1992 Addendum: Mali, U.N. Doc. CRC/C/3/Add. 53 (1997).

115. United Nations, Economic and Social Council; Implementation of the International Covenant on Economic, Social and Cultural Rights - Initial Reports Submitted by States Parties Under Articles 16 and 17 of the Covenant-Addendum: Benin II 397, U.N. Doc. E/ 1990/5/Add.48 (2001). 
1996 that the constitutional guarantee of free education was not translated into practice, as parents bore 70 percent of the cost of primary schooling. ${ }^{116}$ In Gabon, the government acknowledged in 2001 that legal guarantees of free and compulsory education, nominally covering children age six to sixteen were not translated into practice and "schooling is not really free." 117 Similarly, in Mauritania, public education is by law free, but "parents are often called upon to contribute to the purchase of supplies and textbooks, and to participate in the building and upkeep of school premises."118

The Democratic Republic of Congo has acknowledged the abyss between the law and reality by stating that the law requires "primary education to be free of charge" while

the State has been shifting the burden massively on to parents, who must finance the running of schools and the teachers' pay. In short, they must meet very heavy school expenses calculated in hard currency, whereas most heads of family are unemployed or have not been paid for several months. ${ }^{119}$

A similar, albeit unacknowledged, abyss between the constitutional pledge and reality exists in Equatorial Guinea. Although the 1991 Constitution guarantees "the right to general basic education which shall be compulsory, free and guaranteed," 120 half of school-age children were not attending school in $1996 .{ }^{121}$ In

116. Rapport national sur le developement de l'éducation, Commission nationale tschadienne pour l'UNESCO, N'D jamena (July 1996).

117. United Nations, Convention on the Rights of the Child, Committee on the Rights of the Child; Consideration of Reports Submitted by States Parties Under Article 44 of the Convention - Initial Reports of States Parties Due in 1996-Adpendum: Gabon II 83, U.N. Doc. CRC/C/41/Add.10 (2001).

118. United Nations, Convention on the Rights of the Child, Committee on the Rights of the Child; Consideration of Reports Submitted by States Parties Under Article 44 of the Convention - Initial Reports of States Parties Due in 1993-Addendum: Mauritania II 267, U.N. Doc. CRC/C/8/Add.42 (2001).

119. United Nations, Convention on the Rights of the Child, Committee on the Rights of the Child; Consideration of Reports Submitted by States Parties Under Article 44 of the Convention - Initial Reports of States Parties Due in 1992-Addendum: Democratic Republic of the Congo II 149, 156, U.N. Doc. CRC/C/3/Add.57 (2000).

120. Guinea Const.

121. See United Nations, Economic and Social Council, Commission on Human Rights; Report on the Human Rights Situation in the Republic of Equatorial Guinea 10 66, U.N. Doc. E/CN.4/1996/67 (1996). 
2001, the last year when the Special Representative on Equatorial Guinea visited the country, the budgetary expenditure for education further decreased and, consequently, so did the coverage of education. ${ }^{122}$

The financial obligations of parents regarding their children's education have been regulated in Liberia. The law says:

Every parent, guardian or other persons having control of any child between the ages of six and sixteen years shall cause such child to attend a recognized public or private school regularly during the entire time the school is in session, provided such parents or guardians have the means to meet the minimum requirements of the school... . The law on completely free education at the elementary and junior high school levels shall be left dormant during the next five years. ${ }^{123}$

Such an imposition of the whole financial burden on parents has been criticized in Madagascar: "Children are the responsibility of the family, which itself cannot always afford to contribute to the costs of the child's needs [and] operating the school cooperative." 124 In Mozambique, the government acknowledged in 2001 that direct costs of education borne by school children's families were not known, but were assumed to cover all costs except teachers' salaries. ${ }^{125}$

122. See United Nations, Economic and Social Council, Commission on Human Rights; Report on the Human Rights Situation in the Republic of Equatorial Guinea il 84, U.N. Doc. E/CN.4/2001/38 (2001).

123. United Nations, Convention on the Rights of the Child, Committee on the Rights of the Child; Consideration of Reports Submitted by States Parties Under Article 44 of the Convention-Initial Reports of States Parties Due in 1995-Addendum: Liberia ff 194, U.N. Doc. CRC/C/28/Add.21 (2003).

124. United Nations, Convention on the Rights of the Child, Committee on the Rights of the Child; Consideration of Reports Submitted by States Parties Under Article 44 of the Convention - Initial Reports of States Parties Due in 1993-Addendum: Madagascar If 220 , U.N. Doc. CRC/C/8/Add.5 (1993); see also id. at If 218.

125. "There are no systematic data on which to quantify the importance of the direct contribution by households to education. However, there is evidence that in most urban and peri-urban schools, excluding wages, which are all paid by the State, funds for non-wage expenditure come from cash contributions the level of which is decided upon by joint agreement between parents and the schools." United Nations, Convention on the Rights of the Child, Committee on the Rights of the Child; Consideration of Reports Submitted by States Parties Under Article 44 of the Convention-Initial Reports of States Parties Due in 1996-Addendum: Mozambique If 458, U.N. Doc. CRC/C/41/Add.11 (2001). 
In Côte d'Ivoire, "the wish of the Government to provide education for all" was exemplified in 2000 by a reference to a reduction in registration fees at public primary schools. ${ }^{126}$ In Gambia, the cost of education, especially school fees, was identified as the major "barrier to educational participation of the poor who constitute one third of the Gambian population[,]"127 which led to a commitment of the government to make primary education free.

In Namibia, the government position has been that primary education is free, as required by the Constitution. The government reported in 1993 that "school fees are seldom charged." 128 A different reality has been depicted by Wainaina and Katjita:

[A]lthough the payment of school fees was not compulsory for those parents who genuinely could not afford it, the schools which depended on those fees put a lot of pressure [on the parents]. At times contributions other than the official school fees are imposed on the parents. Again, although officially the wearing of school uniforms was not compulsory, educational institutions put a lot of pressure on all the learners to be in uniform. ${ }^{129}$

The importance of education for countries torn by armed conflicts has been amply reiterated on all levels, from global to local, but it does not inform conflict-resolution and post-conflict strategies and the associated global funding strategies. Denial of the right to education makes the parental ability to pay school fees the decisive criterion for children's schooling. In Burundi, the gov-

126. See United Nations, Convention on the Rights of the Child, Committee on the Rights of the Child; Consideration of Reports Submitted by States Parties Under Article 44 of the Convention - Initial Reports of States Parties Due in 1993-Addendum: Côte D'Ivoire If 83, U.N. Doc. CRC/C/8/Add.41 (2000).

127. United Nations, Convention on the Rights of the Child, Committee on the Rights of the Child; Consideration of Reports Submitted by States Parties Under Article 44 of The Convention - Initial Reports of States Parties Due in 1992-Addendum: Gambia II 1 183, 189, U.N. Doc. CRC/C/3/Add.61 (2000).

128. United Nations, Convention on the Rights of the Child, Committee on the Rights of the Child; Consideration of Reports Submitted by States Parties Under Article 44 of the Convention-Initial Reports of States Parties Due in 1992-Addendum: Namibia If 346, U.N. Doc. CRC/C/3/Add.12 (1993).

129. P. K. Wainaina \& L. KatjITA, The Provision of Compulsory and Free Primary Education in Namibia (1990-2000): The Juggling Act, in The Constitution at Work: 10 Years of Namibian Nationhood 337, 342 (Manfred O. Hinz et al. eds., 2003). 
ernment claimed in 1998 that "[t]he fees which parents have to pay for primary education are relatively affordable[,]" without providing evidence that this was the case. ${ }^{130}$ Indeed, the government itself faulted its own scheme of prohibiting the exclusion of poor children from school because it did not work in practice: "The ministerial directive is firm and clear: there shall be no discrimination against indigent children. In practice, however, headmasters continue to send indigent pupils home, if they have not paid their fees." ${ }^{131}$ In 1999, the government announced that school fees would be increased. ${ }^{132}$

The Constitution of Rwanda, adopted in June 2003, says that "[e]very person has the right to education." 133 It does not specify what this right entails, hence it is not possible for children to claim free education until there is a clarification of what the government is obliged to provide. The existing information demonstrates that education is not free, and a survey in 2001 found school fees and the prices of meals and uniforms to be "the principal factor for parental decisions not to send their children to school." 134 The freeing of education from direct costs would respond to a 1999 finding by the Special Representative that "Rwanda would ... benefit enormously from an effective system of free public education." 135 Moreover, the Special Representative "urge[d] the Government of Rwanda to give serious consideration to measures leading to the establishment of a system of free public education, at the very least at [the] primary level...."136 The govern-

130. United Nations, Convention on the Rights of the Child, Committee on the Rights of the Child; Consideration of Reports Submitted by States Parties Under Article 44 of the Convention-Initial Reports of States Parties Due in 1992-Addendum: Burundi If 194 , U.N. Doc. CRC/C/3/Add.58 (1998).

131. Id.

132. "The financing of education is provided by the State and by parents. An increase in the registration fee ("minerval") is planned for school year 1999-2000. A part of it will be earmarked for funding school textbooks, for the functioning of primary schools and for school inspections." République du Burundi, Ministère de l'Éducation Nationale: Bilan de l'Éducation Pour Tous à l'an 2000, Rapport préliminaire, Bujumbura, Août (1999).

133. Rwanda Const. art. 40 (2003).

134. Ministry of Finance, Core Welfare Indicators Questionnaire Survey, National Poverty Reduction Programme (2001).

135. United Nations, Economic and Social Council, Commission on Human Rights; Question of the Violation of Human Rights and Fundamental Freedoms in any Part of the World-Report on the Situation of Human Rights in Rwanda If 55, U.N. Doc. E/CN.4/1999/ 33 (1999).

136. Id. at If 84 . 
ment of Sierra Leone acknowledged in 1996 that education "is not a right yet,"137 and in 2000, the Committee on the Rights of the Child noted that the government undertook "efforts to provide free education to children in the first three years of primary school." 138 However, the Committee also noted that government assistance to "pupils and parents only covers school fees and does not provide for other education related costs." 139 The Security Council, which has had children and armed conflict on its agenda since 1998, was presented in January 2004 with a long list of countries with on-going conflicts ${ }^{140}$ and little information on a peace dividend from which school children could benefit. The representative of Angola noted that "[i]n 2003, more than 600,000 children affected by conflict had been successfully reintegrated into the educational system[,]" but education was not made free; only birth registration certificates for the newly born were exempt from the charges levied on public services. ${ }^{141}$ Human Rights Watch provided a part of the background for the absence of free public services by reporting on $\$ 4.22$ billion in "unaccounted for funds" from 1997 to 2002, which equalled total social spending, including all aid, in the same period. ${ }^{142}$

A growing number of African governments are committed to making primary education free, especially by eliminating direct charges. Malawi set the

137. United Nations, Convention on the Rights of the Child, Committee on the Rights of the Child; Consideration of Reports Submitted by States Parties Under Article 44 of the Convention - Initial Reports of States Parties Due in 1992-Addendum: Sierra Leone $\mid$ 77(b), U.N. Doc. CRC/C/3/Add.43 (1996).

138. United Nations, Convention on the Rights of the Child, Committee on the Rights of the Child; Consideration of Reports Submitted by States Parties Under Article 44 of the Convention-Concluding Observations of the Committee on the Rights of the ChildAddendum: Sierra Leone I 65, U.N. Doc. CRC/C/15/Add.116 (2000).

139. Id.

140. See Children and Armed Conflict, Report of the Secretary-General, U.N. ESCOR, 58th Sess., Annex 1, Agenda Item 113, U.N. Doc. A/58/546-S/2003/1053 (2003) (providing a list of countries on the Security Council's agenda, which includes Afghanistan, Burundi, Cote d'Ivoire, Democratic Republic of the Congo, Liberia, and Somalia); see also id. at Annex 2, Agenda Item 113 (providing a list of countries on the Security Council's agenda, which includes Chechnya, Colombia, Myanmar, Nepal, Northern Ireland, Philippines, Sri Lanka, Sudan, and Uganda).

141. U.N. SCOR, Despite Progress in Protecting Children in Armed Conflict, General Situation Remains 'Grave and Unacceptable,' Security Council Told, Press Release SC/7985 (Jan. 20, 2004).

142. Some Transparency, No Accountability: The Use of Oil Revenue in Angola and Its Impact on Human Rights, Hum. RTs. WATch, Jan. 2004, at 1. 
precedent in $1994 ; ;^{143}$ Uganda followed in $1997 ;{ }^{144}$ Cameroon announced that primary education would be free in $2000 ;{ }^{145}$ Lesotho, ${ }^{146}$ Nigeria, ${ }^{147}$ and Tanzania followed in 2001; $;^{148}$ and Kenya in 2003. ${ }^{149}$ Their commitments, if translated into reality, could be gradually extended throughout the continent and alter its future. As is well known, countries with uneducated children develop into countries without a future.

143. See United Nations, Convention on the Rights of the Child, Commitree on the Rights of the Child; Consideration of Reports Submitted by States Parties Under Article 44 of the Convention - Initial Reports of States Parties Due in 1993-Addendum: Malawi II 254-55, U.N. Doc.CRC/C/8/Add.43 (2001) ("In 1994, the new Government introduced a programme called Free Primary Education (FPE). The FPE programme abolished the payment of tuition and all forms of charges and also abolished a school uniform requirement.").

144. United Nations, International Convention on the Elimination of All Forms of Racial Discrimination, Committee on the Elimination of Racial Discrimination; Reports Submitted by States Parties Under Article 9 of the Convention - Tenth Periodic Reports of States Parties Due in 1999-Adpendum: Uganda 9 - 86, U.N. Doc. CERD/C/358/Add.1 (2001) ("Government has introduced universal primary education (UPE), whereby four children per family are entitled to free primary education.").

145. U.N., Debate Continues on Report of High Commissioner for Human Rights, Press Release (Mar. 22, 2000) (stating that Cameroon Minister of State, Kontchou Kouomegni, claimed that “[a]s of next school year [2001] education would be mandatory and free of charge.").

146. The World Bank reported in 1999 that Lesotho was planning to eliminate school fees in primary education, adding that the government "is aware that such a move has serious budgetary implications." The World Bank-Project Appraisal Document, Second Education Sector Development Project, Report No. 18388-LSO, Mar. 25, 1999. Primary education was made free for children who started primary school in 2000.

147. A Universal Basic Education Programme was launched in September 1999, with the aim of, inter alia, providing free and compulsory universal basic education for every Nigerian child. Olusegun Obasanjo, President of Nigeria, A Fairer, More Stable World, EFA 2000 Bull., No. 38, Jan.-Mar. 2000.

148. "In a reversal of past policies it was decided to abolish school fees and all enrolment related charges and cash contributions with effect from financial year 2001/2002. Having abolished enrolment related school fees and contributions it became possible to enforce the compulsory enrolment provision in the education law." Joseph Mungai, United Republic of Tanzania Minister for Education and Culture, Sector-based Education Aid Seen from a Partner Country, Address at the Nordic Solidarity Conference (June 4, 2002).

149. The abolition of school fees was an electoral pledge of the National Rainbow Coalition (NARC). "One of the first acts of the new government was to honour one of the most important of NARC's election pledges - to introduce free primary education across the nation." Suzie Ochieng, Kenya: 40 Years of Independence, New Afr., Jan. 2004, at 23. The World Bank announced a US\$50 million grant in support of the Free Primary Education Project. Press Release, The World Bank, World Bank Approves US\$110 Million in Development Support to Kenya, News Release No. 2003/443/AFR (June 20, 2003). 
B. Asia

Direct charges in primary education are widespread in primary schools in Asia. The legal guarantee of free education has been made in only half of these countries-eleven out of twenty-two-as Table 4 shows; the recognition of the right to education is also less widespread than in other regions. Furthermore, the absence of compulsory educational laws testifies to a different view of how education should be designed. ${ }^{150}$ Sri Lanka's insistence on a formal guarantee of free education thus merits a mention:

The free education system was further reinforced by several other policies which enabled poor children to participate in education. A free textbooks scheme has operated for most of the period since the 1950s. A free mid-day meal was provided from the 1950s till

150. Education is not compulsory according to national educational law in Bhutan, Fiji, Maldives, Nepal, and Vanuatu. See United Nations, Convention on the Rights of the Child, Committee on the Rights of the Child; Consideration of Reports Submitted by States Parties Under Article 44 of the Convention-Initial Reports of States Parties Due in 1992 Addendum: Bhutan II 138, U.N. Doc. CRC/C/3/Add.60 (1999); United Nations, Convention on the Rights of the Child, Committee on the Rights of the Child; Consideration of Reports Submitted by States Parties Under Article 44 of the Convention-Initial Reports of States Parties Due in 1995: Fiji If 202, U.N. Doc. CRC/C/28/Add.7 (1996); United Nations, Convention on the Rights of the Child, Committee on the Rights of the Child; Consideration of Reports Submitted by States Parties Under Article 44 of the Convention - Initial Reports of States Parties Due in 1993-Addendum: Maldives If 95, U.N. Docs. CRC/C/8/ Add.33 (1996); United Nations, Convention on the Rights of the Child, Committee on the Rights of the Child; Consideration of Reports Submitted by States Parties Under Article 44 of the Convention - Concluding Observations of the Committee on the Rights of the Child-Addendum: Maldives II 21, U.N. Doc. CRC/C/15/Add.91 (1998); United Nations, Convention on the Rights of the Child, Committee on the Rights of the Child; Consideration of Reports Submitted by States Parties Under Article 44 of the Convention - Initial Reports of States Parties Due in 1992-Addendum: Nepal If 9 63, 293, U.N. Doc. CRC/C/3/ Add.34 (1995); United Nations, Convention on the Rights of the Child, Committee on the Rights of the Child; Consideration of Reports Submitted by States Parties Under Article 44 of the Convention - Initial Reports of States Parties Due in 1995-Addendum: VanUATU II 31, U.N. Doc. CRC/C/28/Add.8 (1997). In Malaysia, according to government statistics, 99\% of school-age children attend school although education is not compulsory. MiNisTry of Educ. Malaysia, at http://www.moe.gov.my (last visited Feb. 3, 2005). However, effective January 2003, primary education in Singapore is compulsory. United Nations, Convention on the Rights of the Child, Committee on the Rights of the Child; Consideration of Reports Submitted by States Parties Under Article 44 of the Convention-Initial Reports of States Parties Due in 1997-Addendum: Singapore 1 4 419, U.N. Doc. CRC/C/51/Add.8 (2003). 
1964, when it was discontinued. It was reintroduced in 1989. There is some evidence that school enrolment and school attendance have been greater during periods when a mid-day meal has been provided. In 1991, a free school uniform was also provided. These measures ... have meant that the parental costs for education have been minimal. ${ }^{151}$

The right to education has been part of constitutional guarantees in Sri Lanka for a long time, although it remains unsettled what its nature and scope is and how it should best be protected against different policies of changing governments and the long heritage of armed conflict in the country. The government reported in 2002 that a constitutional reform had been initiated to ensure "free education provided by the State for children between the ages of 5 and 14." 152 In Thailand, the 1997 Constitution guaraunteed twelve years of free education for all children. ${ }^{153}$

The fragmentation of governments' human rights commitments is reflective of a partial adherence to international human rights treaties and the absence of an Asian set of human rights standards or a regional human rights organization. Asia is the only region where such an organization has not been created owing to diverse views of the role of the state and relations between the individual and the state. These are expressed in the varied legal guarantees related to the right to education. Some constitutions guarantee freedom of education and empower communities, particularly religious communities, to organize and carry out the education of their children, rather than imposing public and uniform schooling upon the entire population. Education, thus, may be all-encompassing but neither provided nor paid for by the state. Others reflect the previous Soviet model of uniform, state-provided, free, and compulsory education, which denies freedom of choice. It is illustrative that in countries where an ideologically

151. United Nations, Economic and Social Council; Implementation of the International Covenant on Economic, Social and Cultural Rights - Initial Reports Submitted by States Parties Under Articles 16 and 17 of the Covenant-Addendum: Sri Lanka 1 318, U.N. Doc. E/1990/5/Add.32 (1997).

152. United Nations, Convention on the Rights of the Child, Committee on the Rights of the Child; Consideration of Reports Submitted by States Parties Under Article 44 of the Convention-Second Periodic Reports of States Parties Due in 1998-Addendum: SRi LANka If 74(f), U.N. Doc. CRC/C/70/Add.17 (2002).

153. The 1997 Constitution states "A person shall enjoy an equal right to receive the fundamental education for the duration of not less than twelve years which shall be provided by the State thoroughly, up to the quality, and without charge." Thatl. Const. ch. $3, \S 43$. 
driven constitutional guarantee of free education persists (Cambodia, China, Laos, Myanmar, and Vietnam), practice does not conform to the pledge.

In Cambodia, though the government asserts the constitutional guarantee to a free education in human rights reports, the same reports claim that education is not actually free in practice. ${ }^{154}$ The Special Rapporteur on Cambodia clarified the situation in 2002:

The Constitution guarantees free quality education. In practice, families carry about two thirds of the financial burden of their children's schooling. ... Families are still charged unofficial fees starting at a few hundred riel a day and rising to several thousand (from approximately US 5 to 75 cents or more) depending on the school and the age of the student.... The cost of education is often prohibitive for [people living below the poverty line], meaning that children are withdrawn from school and put to work in subsistence farming. ... A 2001 Ministry of Education circular abolishing entrance fees for primary and lower secondary education has contributed to an increase in the number of children enrolled in schools. According to the Ministry data, 380,000 new students enrolled during the school year starting in September 2001. ${ }^{155}$

This has partially clarified this unusual situation, where the government quotes what the law says only to acknowledge that the law does not guide its practice, and then the government formally bans the charging of some fees, which should not have been charged in the first place.

154. In a 1998 U.N. report, the government quoted the constitutional guarantee: "The State shall provide all citizens with primary and secondary education in State schools free of charge. Citizens shall receive education for at least 9 years." United Nations, Convention on the Rights of theChild, Committee on the Rights of the Child; Consideration of Reports Submitted by States Parties Under Article 44 of the Convention - Initial Reports of States Parties Due in 1994-Addendum: Cambodin II 189, U.N. Doc. CRC/C/11/Add.16 (1998). The report continues, "general education in Cambodia is, in principle, free of charge and available to all." Id. at II 196. However, the report later cites practical costs incurred by families: "Research has shown that each family spends at least $123[]$,000 riels a year on each child receiving primary education (contribution to the school $48 \%$, purchase of books and exercise books $8 \%$, extra tuition $21.2 \%$, miscellaneous costs 4.9\%)." Id. at II 199 (citation omitted).

155. Situation of Human Rights in Cambodia: Report of the Secretary-General, U.N. GAOR, 57th Sess., Agenda Item 109(c), II II 56, 59, 64, U.N. Doc. A/57/230 (2002). 
Table 4: Asia

\begin{tabular}{|c|c|c|c|c|}
\hline \multirow[t]{2}{*}{ Country } & \multicolumn{2}{|c|}{$\begin{array}{l}\text { Legal guarantee } \\
\text { of free education }\end{array}$} & \multicolumn{2}{|c|}{$\begin{array}{l}\text { School fees } \\
\text { charged }\end{array}$} \\
\hline & Yes & No & Yes & No \\
\hline Bangladesh & $\sqrt{ }$ & & $\sqrt{ }$ & \\
\hline Bhutan & j & & j & \\
\hline Cambodia & $\sqrt{ }$ & & $\sqrt{ }$ & \\
\hline China & $\sqrt{ }$ & & $\sqrt{ }$ & \\
\hline Fiji & & $\sqrt{ }$ & $\sqrt{ }$ & \\
\hline India & 1 & & $\sqrt{ }$ & \\
\hline Indonesia & & $\sqrt{1}$ & $\sqrt{ }$ & \\
\hline Korea & $\sqrt{ }$ & & & $\sqrt{ }$ \\
\hline Laos & & $\sqrt{ }$ & $\sqrt{ }$ & \\
\hline Malaysia & & $\sqrt{ }$ & & $\sqrt{ }$ \\
\hline Maldives & & $\sqrt{ }$ & $\sqrt{2}$ & \\
\hline Mongolia & $\sqrt{ }$ & & $\sqrt{ }$ & \\
\hline Myanmar & & $\sqrt{ }$ & $\sqrt{ }$ & \\
\hline Nepal & $\sqrt{ }$ & & $\checkmark$ & \\
\hline Pakistan & & $\sqrt{1}$ & $T$ & \\
\hline Papua New Guinea & & $\sqrt{2}$ & $\sqrt{ }$ & \\
\hline Philippines & $\sqrt{1}$ & & $\sqrt{ }$ & \\
\hline Singapore & & $\sqrt{1}$ & $\sqrt{ }$ & \\
\hline Sri Lanka & $\sqrt{ }$ & & & $\sqrt{ }$ \\
\hline Thailand & $\sqrt{1}$ & & & $\checkmark$ \\
\hline Vanuatu & & $\sqrt{1}$ & $\sqrt{ }$ & \\
\hline Viet Nam & $\sqrt{ }$ & & $\sqrt{ }$ & \\
\hline
\end{tabular}

The situation is even more complicated in China. The government routinely quotes the law, which does not allow fees to be charged in compulsory education. "Article 10 [of the 1986 Compulsory Education Act] reads: 'The State shall not charge tuition fees for students attending compulsory education." 156 However, direct charges have been regulated by the government despite the fact that they should not have been charged in the first place. Direct charges are called "miscellaneous fees," which provide ample latitude for local authorities and schools to charge for everything, including tuition, by creatively naming

156. United Nations, Convention on the Rights of the Child, Committee on the Rights of the Child; Consideration of Reports Submitted by States Parties Under Article 44 of the Covenant-Initial Reports of States Parties Due in 1994-Addendum: China I1 165, U.N. Doc. CRC/C/1 1/Add.7 (1995). 
such charges. "The schools run for compulsory education by the state could only collect miscellaneous fee[s] and at the non-compulsory education stage the tuition and miscellaneous fee[s] could be drawn." 157

Similarly, the government of Laos also claims that education is free, but this claim has been questioned by the Committee on the Rights of the Child ${ }^{158}$ and undermined by the Asian Development Bank. ${ }^{159}$ Nepal reported in 2000 that "the Government has declared primary education free[,]"160 but this "declaration" has not been translated into government policy. ${ }^{161}$ Vietnam, like China, has a constitutional provision that defines education as both a right and an obligation and also stipulates that primary education should be compulsory and free. ${ }^{162}$ This, also like China, is not so in practice. ${ }^{163}$ The government of North Korea is the only one in the world that claims that the right to education is fully enjoyed

157. State Educ. Comm'n, P.R.C., The Development and Reform of Education in China 1995-1996, at 13 (1996).

158. United Nations, Convention on the Rights of the Child, Committee on the Rights of the Child; Consideration of Reports Submitted by States Parties Under Article 44 of the Conenant - Concluding Observations of the Committee on the Rights of the ChildAddendum: Lao People's Democratic Republic II 24, U.N. Doc. CRC/C/15/Add.78 (1997).

159. "Many communities are significantly involved in school affairs by contributing funds [and] providing labor for construction." Asian Dev. Bank, Lao People's Democratic Republic: Education Sector Development Plan, at ix (2000), available at http://www.adb.org/Documents/ Books/Lao_Education_Sector_Dev/default.asp (last visited Feb. 5, 2005).

160. United Nations, Economic and Social Council; Implementation of the International Covenant on Economic, Social and Cultural Rights - Initial. Reports Submitted by States Parties Under Articles 16 and 17 of the Covenant-Addendum: Nepal II 161, U.N. Doc. E/ 1990/5/Add.45 (2000).

161. The Child Workers in Nepal Concerned Centre (CWIN) has commented on the formal abolition of school fees without additional public funding needed to compensate the loss of previous direct charges: "The government has directed not to charge admission fees in the primary schools, but the schools are charging fees in one or other way [sic]." ChILD Workers in NePal Concerned Centre, The State of The Rights of The Child in Nepal 2003, at 6 (2003), available at hetp:// www.cwin-nepal.org/resources/reports/index.htm/ (last visited Feb. 3, 2005).

162. "The citizen has both the right and the duty to receive training and instruction. Primary education is compulsory and dispensed free of charge." Vietnam Const. ch. 5, art. 59.

163. "[T] he government's official fee policy plays a minor role in determining the full price that families face in sending a child to public school... In urban areas, each child enrolled in a public primary school pays on average about VND 261,000 per year (\$24) ... despite the fact that official school fees are zero." The World Bank, Vietnam Education Financing 53 (1997), available at http://www-wds.worldbank.org/servlet/WDS_IBank_Servlet? pcont = details\&eid=000009265_ 3971113151139 (last visited Feb. 3, 2005). 
by everybody, ${ }^{164}$ but there is no independent verification of that assertion. The government of Myanmar also claims that education is free, but the opposite was proven by the Special Rapporteur on Myanmar. ${ }^{165}$

"Pakistan's Constitution provides that the State shall ... provide free and compulsory education within a minimum possible period." 166 Decades after the adoption of the constitution this has not happened. In Bhutan, the government has reported that education is free, but added in the same report that fees were charged. ${ }^{167}$ The Constitution of the Philippines obliges the government to ensure that both primary and lower secondary education are free, ${ }^{168}$ but this has

164. By the progressive education system and the popular policy of education, every citizen fully enjoys the right to education. The right to education and its realization is guaranteed by the Constitution and the legislation on education.... Education has been completely free in every educational institution since March 1959 by the Cabinet Decision on abolishing tuition fees.... In the DPRK, there is nobody who has not received primary education thanks to the universal compulsory primary education system that has been enforced since 1956.

United Nations, Economic and Social Council; Implementation of the International Covenant on Economic, Social and Cultural Rights-Second Periodic Reports Submitted by States Parties Under Articles 16 and 17 of the Conenant - Addendum: Democratic People's Republic OF Korea II 84, 87-88, U.N. Doc. E/1990/6/Add.35 (2002).

165. Official figures of net enrolment and retention rates of school-age children reveal that only half of Myanmar children aged 5 to 15 years complete the primary cycle. Based on these figures, it is estimated that 25 percent of children never enrol and, out of those who do, only one third are able to complete the full five-year cycle of primary schooling. Furthermore, approximately one quarter of the children in age group 10-14 (about 1.25 million children) are engaged in paid work.

Situation of Human Rights in Myanmar: Note by the Secretary-General, U.N. GAOR, 56th Sess., Agenda Item 131(c), II 68, U.N. Doc. A/56/312 (2001).

166. United Nations, Convention on the Rights of the Child, Committee on the Rights of the Child; Consideration of Reports Submitted by States Parties Under Article 44 of the Convention-Initial Reports of States Parties Due in 1993-Addendum: Pakistan II 121 , U.N. Doc. CRC/C/3/Add.13 (1993).

167. United Nations, Convention on the Rights of the Child, Committee on the Rights of the Child; Consideration of Reports Submitted by States Parties Under Article 44 of the Convention - Initial Reports of States Parties Due in 1992-Addendum: Bhutan fl 39, U.N. Doc. CRC/C/3/Add.60 (1999) (stating that "education is free"); id. at Il 160 ("Apart from a nominal fee of $\mathrm{Nu} 5$ per annum per student, all schooling facilities are provided free. In addition, schools collect from $\mathrm{Nu} 10$ to $\mathrm{Nu} 300$ per student per annum for the school development fund."). 168. Phil. Const. art. XIV, \& 2(2). The 1986 Constitution states: "The State shall . . [ [e]stablish and maintain a system of free public education in the elementary and high school levels. Without limiting the natural rights of parents to rear their children, elementary education is compulsory for all children of school age." In addition, "the State shall assign the highest budgetary priority to education." Id. at art. XIV, $\S 5(5)$. 
not been translated into reality throughout the country. In 1995, the Mongolian government described the gap between the constitutional guarantee of free education for everybody up to the age of seventeen and the difficulties that families faced when the government's budgetary expenditures plummeted with the transition to the free market. ${ }^{169}$

The government of Bangladesh reported in 1995 that the Bangladesh "Constitution guarantees the right to education and training, including every citizen's right to free primary education." 170 The government of Bangladesh has made eight years of primary education "completely free[,]"171 and according to the government's self-assessment, ten years of free schooling are offered to girls as an incentive to encourage them to enroll. ${ }^{172}$ In India, the eighty-sixth Constitutional Amendment transformed the right to education from a directive for state policy (as it is in Bangladesh) into an individual right. ${ }^{173}$ The legislative process, whereby this constitutional guarantee should be translated into an enforceable right to education for every child, is ongoing.

The government of Fiji has reported that "the cost of providing free educa-

169. United Nations, Convention on the Rights of the Child, Committee on the Rights of the Child; Consideration of Reports Submitted by States Parties Under Article 44 of the Convention-Initial Reports of States Parties Due in 1992-Adpendum: Mongolia II 15 , U.N. Doc. CRC/C/3/Add.32 (1995) (stating that "Government expenditure on health, education and other social insurances has decreased sharply.... It has had a negative impact on the situation of children and women."). "The average expenditure per child per year for a family to pay is around US $\$ 100$. This is not a small amount for those poor families, and also for those parents who are working in State-budgeted organizations. Therefore, there is a need to cover those families in the social security net and with insurance in order to enable them to send their children to school." Id. at $\mathbb{I} 196$.

170. United Nations, International Convention on the Elimination of All Forms of Racial Discrimination, Committee on the Elimination of Racial Discrimination; Reports Submitted by States Parties Under Article 9 of the Convention-Eleventh Periodic Reports of States Parties Due in 2000-Addendum: Bangladesh II 54, U.N. Doc. CERD/C/379/ Add.1 (2000).

171. Id.

172. Primary and Mass Education Division, Government of the People's Republic of Bangladesh, Education for All: The Year 2000 Assessment Bangladesh Country Report, Part II: Analytic Section, Progress Towards Goals and Targets, at http://www2.unesco.org/wef/ countryreports/bangladesh/contents.html (last visited Feb. 5, 2005).

173. INDIA Const. art. $21 \mathrm{~A}$, amend. 86 ("The State shall provide free and compulsory education to all children of the age of six to fourteen years in such a manner as the State may, by law determine."). The Constitution 93rd Amendment Bill 2001 was passed by unanimous vote in the Lok Sahba on November 27, 2001 and by Rajya Sabha on May 14, 2002. 
tion to all children would be prohibitive." ${ }^{174}$ Education is thus neither free nor compulsory. Indonesia has one of the oldest constitutional guarantees of the right to education, which predates the Universal Declaration of Human Rights by three years. ${ }^{175}$ The interpretation of the right to education therein does not include a requirement that primary education should be free. ${ }^{176}$ Malaysia reserved the right not to make education free and compulsory when it ratified the Convention on the Rights of the Child. ${ }^{177}$ Its constitution does not guarantee a right to education, but provides safeguards against discriminatory exclusion from education. ${ }^{178}$ In Singapore, which has laws that differentiate between citizens and noncitizens, only noncitizens are obliged to pay school fees for education. ${ }^{179}$

174. United Nations, Convention on the Rights of the Child, Committee on the Rights of the Child; Consideration of Reports Submitted by States Parties Under Article 44 of the Convention-Initial Reports of States Parties Due in 1995-Addendum: Fiji II 202, U.N. Doc. CRC/C/28/Add. 7 (1996).

175. Indon. Const. ch. XIII, art. $31, \S \S 1-2$, reprinted in 18 Constitutions of The Countries of THE WorLd (Albert P. Blaustein \& Gisbert H. Flanz eds., 1990). Indonesia's 1945 Constitution says: "Every citizen shall have the right to obtain education," and "[t]he Government shall create and execute a system of national education provided by law." Id.

176. "Sources from parents are usually in the form of monthly fees, entrance fees, term and final test fees, and extra curriculum fees. ... On average, fees contribute $35 \%$ of the total school revenue, excluding teachers' salaries."McMahon et al., Ministry of National Education (MONE), UNICEF and UNESCO, Improving Education Finance in Indonesia (2002).

177. Country-by-Country Tables, Ratifications of Human Rights Treaties, at http://www.rightto-education.org (last visited Feb. 5, 2005).

178. See Human Rights Commission of Malaysia, Report of Forum on Human Rights of the Disadvantaged 2001, 57 (2002), available at http://www.suhakam.org.my/en/document_resource/ details.asp? id $=33$ (last visited Feb. 5, 2005) (describing the pattern of exclusion from education which includes, inter alia, children without birth certificates and identity documents).

179. In the primary school, Singaporean pupils and those who are children of Singaporeans do not pay school fees.... Non-citizen pupils in the primary school pay school fees at different rates. Those whose parents are permanent residents, employment pass holders and diplomats of foreign embassies pay a concessionary rate of $\$ \$ 36$ (about US $\$ 20$ ) per annum. Other non-citizens pay $\$ \$ 960$ (about US\$640) per annum. Still, these rates are much lower than the actual cost $(\$ \$ 2,865)$ per annum of educating a child in primary school.... [I]n line with the philosophy that parents must be responsible for their children's education, miscellaneous fees are charged to all pupils in order to meet part of the cost of materials and supplies that are used in school. The rate of the miscellaneous fees at the primary school level is $\$ \$ 10$ per month.

United Nations, Convention on the Rights of the Child, Committee on the Rights of the Child; Consideration of Reports Submitred by States Parties Under Article 44 of the Convention-Initial Reports of States Parties Due in 1997-Addendum: Singapore III 422-23, U.N. Doc. CRC/C/51/Add.8 (2003). 


\section{Eastern Europe and Central Asia}

The transition from a centrally planned economy to a market economy has had a profound and negative effect on free and compulsory education in Eastern Europe and Central Asia. Some features of the previous, Soviet-modelled education were merged with the newly introduced free market in education. Table 5 illustrates the continuing heritage of constitutional guarantees of free education in all these countries, but also their inability to ensure free education for all children through various charges in the majority of countries.

These governments are generally reluctant to acknowledge the payments for education that should be free. Belarus, Kazakhstan, Turkey, and Uzbek istan have claimed in their reports required by human rights treaties that both primary and secondary education are free of charge. ${ }^{180}$ In Ukraine, the government has reported that both primary and secondary education are free and compulsory, but admitted that "[t]here is a gap between the legally established rights and the practical possibilities of exercising them" caused by the public underfunding of education, arrears in teachers' salaries, and the shortage of textbooks. ${ }^{181}$

180. United Nations, Convention on the Rights of the Child, Committee on the Rights of the Child; Consideration of Reports Submitted by States Parties Under Article 44 of the Convention - Initial Reports of States Parties Due in 1992: Belarus If 89, U.N. Doc. CRC/C/ 3Add.14 (1993); United Nations, Convention on the Rights of the Child, Committee on the Rights of the Child; Consideration of Reports Submitted by States Parties Under Article 44 of the Convention, Periodic Reports of States Parties Due in 1997-A Addendum: Belarus II 189, U.N. Doc. CRC/C/65/Add.15 (2001); United Nations, Convention on the Rights of the Child, Committee on the Rights of the Child; Consideration of Reports Submitted by States Parties Under Article 44 of the Convention-Initial Reports of States Parties Due in 1996-Addendum: Kazakhstan II 257, 277, U.N. Doc. CRC/C/41/Add.13 (2002); see United Nations, Economic and Social Council, Committee on Human Rights; Economic, Social and Cultural Rights - Addendum II 1 25-34, U.N. Doc. E/CN.4/2002/60/Add.2 (2002); United NAtions, Convention on the Rights of the Child, Committee on the Rights of the Child; Consideration of Reports Submitted by States Parties Under Article 44 of the Convention; Initial Reports of States Parties Due in 1996-Addendum: Uzbekistan 1 I 237, 239, U.N. Doc. CRC/C/ 41/Add.8 (2001); United Nations, Convention on the Elimination of All Forms of Discrimination Against Women, Committee on the Elimination of Discrimination Against Women; Consideration of Reports Submitted by States Parties Under Article 18 of the Convention on the Elimination of All Forms of Discrimination Against Women - Initial Reports of States Parties: Uzbekistan 19, 39, U.N. Doc. CEDAW/C/UZB/l (2000)

181. United Nations, Convention on the Rights of the Child, Committee on the Rights of the Child; Consideration of Reports Submitted by States Parties Under Article 44 of the Convention - Second Periodic Reports of States Parties Due in 1998-Addendum: Ukraine II $129,643,685$, U.N. Doc. CRC/C/70/Add. 11 (2001). 
The Russian Federation has reported that its legislation is in line with its international human rights obligations. However, human rights guarantees are part of the federal legislation, while the responsibility for education, including financial responsibility, has been decentralized. The recognition of the right to education and rights in education as well as its enjoyment thus varies a great deal:

The financial responsibility for giving effect to the rights of the child to education is delegated to the regions, whose possibilities are unequal. Regional per capita expenditure on child education varies appreciably (by up to one third).... The shortage of budgetary financing is stimulating the commercialization of education and limiting the availability of high-quality education. ${ }^{182}$

As a consequence of that model of decentralization, the responsibility for guaranteeing free education for all children has been blurred at the expense of children. The pattern of economic exclusion has been depicted by the government itself, which has reported that "[t]he financial difficulties encountered by most Russian families mean that increasing numbers of children are forced to abandon secondary general education." 183 To this, "the real problems prevalent in certain regions (difficult socio-economic situations, large numbers of children from enforced migrant families, including children from areas of interethnic and military conflict, etc.)" are added. ${ }^{184}$ As elsewhere, the pattern of economic exclusion is exacerbated by discrimination, which particularly affects children

182. United Nations, Convention on the Rights of the Child, Committee on the Rights of the Child; Consideration of Reports Submitted by States Parties Under Article 44 of the Convention-Periodic Reports of States Parties Due in 1997-Addendum: Russian FederaTION II 38, 301-02, U.N. Doc. CRC/C/65/Add.5 (1998).

183. United Nations, Convention on the Elimination of All Forms of Discrimination Against Women, Committee on the Elimination of Discrimination Against Women; Consideration of Reports Submitted by States Parties Under Article 18 of the Convention on the Elimination of All Forms of Discrimination Against Women-Fifth Periodic Reports of States Parties: Russian Federation 23, U.N. Doc. CEDaW/C/USR/5 (1999).

184. United Nations, Economic and Social Council; Substantive Session of 2002-Implementation of the International Covenant on Economic, Social and Cultural RightsFourth Periodic Reports Submitted by States Parties in Accordance with Article 16 and 17 of the Covenant - Addendum: Russian Federation 1 453, U.N. Doc. E/C.12/4/Add.10 (2001). 
Table 5: Eastern Europe and Central Asia

\begin{tabular}{|c|c|c|c|c|}
\hline \multirow[t]{2}{*}{ Country } & \multicolumn{2}{|c|}{$\begin{array}{l}\text { Legal guarantee } \\
\text { of free education }\end{array}$} & \multicolumn{2}{|c|}{$\begin{array}{l}\text { School fees } \\
\text { charged }\end{array}$} \\
\hline & Yes & No & Yes & No \\
\hline Albania & $\sqrt{ }$ & & & $\sqrt{1}$ \\
\hline Armenia & $\sqrt{1}$ & & $\sqrt{1}$ & \\
\hline Azerbaijan & $\sqrt{1}$ & & $\sqrt{ }$ & \\
\hline Belarus & $\sqrt{1}$ & & $\sqrt{3}$ & \\
\hline Bosnia and Herzegovina & 4 & & $\sqrt{ }$ & \\
\hline Bulgaria & 1 & & & $\sqrt{ }$ \\
\hline Croatia & J & & & $\sqrt{ }$ \\
\hline FYROM (Macedonia) & 4 & & $\checkmark$ & \\
\hline Georgia & 1 & & $j$ & \\
\hline Kazakhstan & 1 & & & $\sqrt{ }$ \\
\hline Kyrgyzstan & 1 & & $\sqrt{ }$ & \\
\hline Moldova & 1 & & $\sqrt{ }$ & \\
\hline Romania & 1 & & & $\sqrt{ }$ \\
\hline Russia & 1 & & $\sqrt{ }$ & \\
\hline Serbia and Montenegro & 1 & & $\sqrt{ }$ & \\
\hline Tajikistan & 1 & & $\sqrt{ }$ & \\
\hline Turkey & 1 & & & $\sqrt{ }$ \\
\hline Turkmenistan & 1 & & & $\sqrt{1}$ \\
\hline Ukraine & 1 & & $\sqrt{ }$ & \\
\hline Uzbekistan & $\sqrt{1}$ & & $\sqrt{ }$ & \\
\hline
\end{tabular}

denied free education because they do not possess residence permits and thus can only gain access to education if they can pay for it. ${ }^{185}$

In Serbia and Montenegro, increases in the cost of education for families, regardless of legal guarantees of free education, were reported in $1996,{ }^{186}$ and decreases in budgetary allocations to education were acknowledged by the

185. United Nations, International Convention on the Elimination of All Forms of Racial Discrimination; Consideration of Reports Submitted by States Parties Under Article 9 of the Convention - Concluding Observations of the Committe on the Elimination of Racial Discrimination: Russian Federation I14, U.N. Doc. CERD/C/62/CO/7 (2003) (stating that the Committee on the Elimination of Racial Discrimination has been concerned "about numerous reports ... that the lack of residence registration is used to deny a number of political, economic and social rights.").

186. The Committee on the Rights of the Child noted the concern "that the costs of children's education may be growing beyond the reach of certain families." Report of the Committee on the Rights of the Child, U.N. GAOR, 51 st Sess., Supp. No. 41 II 892, U.N. Doc. A/51/41 (1996). 
government in $1999 .{ }^{187}$ Croatia has reported that primary education is free and available to all children ${ }^{188}$ but this is the case only for citizens. Those without citizenship do not have a right to free education, and minority children may not go to school at all. ${ }^{189}$

Albania is an example of a country with a problematic transition, having been included in the list of Highly Indebted Poor Countries (HIPC). ${ }^{190}$ Education has not been immune from the consequences of the impoverishment of both the government and the population, ${ }^{191}$ and the design of education has followed the model for all highly indebted poor countries. In Armenia, for example, the

187. "Owing to the dramatic decline in the ... public funds ... the funds set aside for education were reduced in real terms." United Nations, Economic and Social Council; Implementation of the International Covenant on Economic, Social and Cultural Rights - Second Periodic Reports Submitted by States Parties Under Articles 16 and 17 of the CovenantAddendum: Yugoslavia If 161, U.N. Doc. E/1990/6/Add.22 (1999).

188. United Nations, Economic and Social Council; Implementation of the International Covenant on Economic, Social and Cultural Rights-Initial Reports Submitted by States Parties Under Articles 16 and 17 of the Covenant-Addendum: Croatia 11 407, E/1990/5/ Add.46 (2000); United Nations, Convention on the Rights of the Child, Committee on the Rights of the Child; Consideration of Reports Submitted by States Parties Under Article 44 of the Convention-Initial Report of States Parties Due in 1993: Croatia II 50,316 , U.N. Doc. CRC/C/8/Add.19(1994).

189. See United Nations, Economic and Social Council; Consideration of Reports Submitted by States Parties Under Articles 16 and 17 of the Covenant-Concluding Observations-Addendum: Crontia II 19, U.N. Doc. E/C.12/1/Add.73 (2001) (stating that "children from certain minority groups, in particular the Roma, and children of undocumented aliens may not be going to school").

190. The process of alleviating unsustainable debt for the Highly Indebted Poor Countries (HIPC) requires each country to submit a Poverty Reduction Strategy Paper (PRSP), which aims to "solidify donor and country partnerships around a common development framework." IMF \& World Bank, International Monetary Fund and International Development Association, Poverty Reduction Strategy Papers-Progress in Implementation 9 (Sept. 12, 2003), available at http:/www.imf.org/external/np/ prspgen/2003/091203.pdf (last visited Feb. 5, 2005). The PRSPs include descriptions of the current and planned public financing for education. The first 10 countries to comply with all conditions for PRSP-supported programs were Benin, Bolivia, Burkina Faso, Guyana, Mali, Mauritania, Mozambique, Nicaragua, Tanzania and Uganda, which were joined in July 2004 by 4 additional countries (Ethiopia, Ghana, Niger, and Senegal). The World Bank, Board Presentations of PSRP Documents as of 31 July 2004, available at www.worldbank.org/hipc (last visited Feb. 5, 2005).

191. "In the elementary system, the main cause of dropout and decrease in the number of enrolments was lack of family income and inability to afford the required school expenses." UNICEF, Assessment of Social and Economic Conditions of Districts in Albania (2000), available at http:// www.unicef.org/albania/media_742.html (last visited Feb. 5, 2005). 
entry of the World Bank into education has resulted in school textbooks that are no longer free of charge. ${ }^{192}$

The varied situations in different countries point to two different patterns. Direct charges may be informal and/or illegal because the budgetary allocations for education do not reach schools or are too small. Alternatively, public schools may be formally allowed to charge for their services.

Armenia is an example for levying direct charges informally because schools cannot continue operating owing to the insufficient funds sent to them from the central or local government. The economic difficulties led to the first objective of Armenia's education strategy: "To prevent the educational system from breaking down under conditions of extremely limited financial means." ${ }^{193}$ One facet of the changed circumstances has been low teachers' salaries, which have created an informal system of private tuition. ${ }^{194}$ Georgia has also referred to "an informal system of payments whereby Georgian households fund much of the budget of educational institutions." ${ }^{195}$ Formal legal guarantees of free education have continued unchanged, but the gap between them and the economic exclusion from education seems to be widening.

In Georgia, the boundary between public and private education disappeared as public schools were allowed to charge tuition and other fees. The first eight years of schooling were kept nominally free, with charges levied from the ninth year on-

192. United Nations, Convention on the Rights of the Child, Committee on the Rights of the Child; Consideration of Reports Submitted by States Parties Under Article 44 of the Convention-Initial Reports of States Parties Due in 1995-Addendum: Armenia Il 60, U.N. Doc. CRC/C/28/Add.9 (1997) ("At the suggestion of the Government and on instructions from the World Bank, consultants on textbook issues ... will provide professional assistance in setting up the programme... Contrary to previous practice, the books will not be distributed free, but for a fixed fee representing a year's rental.").

193. United Nations, Economic and Social Council; Implementation of the International Covenant on Economic, Social and Cultural Rights - Initial Reports Submitted by States Parties Under Articles 16 and 17 of the Covenant-Addendum: Armenia II 276, U.N. Doc. E/1990/5/Add.36 (1998).

194. United Nations, Convention on the Rights of the Child, Committee on the Rights of the Child; Report on the Twenty-Third Session II 338, U.N. Doc. CRC/C/94 (2000) (stating that the Committee is "concerned that low wages have forced teachers to offer private tuition, creating a two-tier system of education").

195. United Nations, Economic and Social Council; Implementation of the International. Covenant on Economic, Social and Cultural Rights - Second Periodic Reports Submitted by States Parties Under Articles 16 and 17 of the Covenant-Addendum: Georgia II 240 , U.N. Doc. E/1990/6/Add.31 (2001). 
ward. However, for-fee education was also introduced in the first eight years of schooling: "Fee-paying instruction and other activities are permitted at State-run educational institutions; the profits are at the disposal of the respective institutions' administrations." 196 The permission to charge fees in schools that should have remained free so as to ensure education of poor children was a likely effect of the chronic underfunding of public schools and, perhaps, also of corruption during the previous government. ${ }^{197}$ As a consequence, formal or informal payments for nominally free education have come to cover the entire cost of education. ${ }^{198}$

Azerbaijan's reports required by human rights treaties and its documents on poverty reduction have revealed two parallel developments. In its human rights reports, the government has quoted its legislation that guarantees eight years of free education to all citizens and free secondary education to all those who satisfy the entry criteria. ${ }^{199}$ Within free public education, permission has been granted to enroll paying pupils and students. A complicated scheme ensued where those able to finance their education would do so, while the government would (at least in theory) subsidize the costs for all those unable to afford them. ${ }^{200}$ Azerbaijan's poverty reduction program has highlighted the reasons why public schools were allowed-even forced—to resort to charges: "Almost

196. United Nations Economic and Social Council; Implementation of the International Covenant on Economic, Social and Cultural. Rights - Initial Reports Submitted by States Parties Under Articles 16 and 17 of the Covenant-Addendum: Georgia If 260, U.N. Doc. E/ 1990/5/Add.37 (1998); see also id. at \\256,288.

197. Neil MacFarlane has commented that "[t]he Georgian state started weak and was further damaged by two de facto secessions and a civil war," adding that it was "deeply dependent on western assistance." S. Neil MacFarlane, Georgia's Revolution and the Region: Is it Catching?, WORLD TODAY, Feb. 2004, at 14-15.

198. United Nations, Economic and Social Council; Implementation of the International Covenant on Economic, Social and Cultural Rights - Second Periodic Reports Submitted by States Parties Under Articles 16 and 17 of the Covenant-Addendum: Georgia II 240 , U.N. Doc. E/1990/6/Add.31 (2001) ("Against the backdrop of a chronically underfunded education system ... propitious circumstances have developed ... whereby Georgian households fund much of the budget of educational institutions from their own resources. They contribute to socalled "school funds" and provide fuel to heat school buildings in wintertime, etc.").

199. United Nations, Economic and Social Council; Implementation of the International Covenant on Economic, Social and Cultural Rights - Initial Reports Submitted by States Parties Under Articles 16 and 17 of the Covenant-Addendum: Azerbaijan II 170, U.N. Doc. E/1990/5/Add.30 (1996).

200. "Poorly off pupils in fee-paying educational establishments are paid allowances by the State on the basis of the standard fees payable in State teaching establishments of the same kind and type." Id. at II 167. 
all education[al] institutions lack basic textbooks and teaching materials and supplies to perform an acceptable high standard.... There have also been reductions in the budget funds available for maintenance and repairs, resulting in deterioration in the overall physical conditions of many school buildings, especially in rural areas." 201 In Bulgaria, the emergence of private education started, as elsewhere, at the post-compulsory level and then broadened because of the impoverishment of public education. ${ }^{202}$ The articulation of freedom of choice ${ }^{203}$ in those conditions comes uncomfortably close to affirming that all those who are able to pay for better education for their children can do so, while those without purchasing power are left without choice. In Moldova, the government has reported its legal guarantees of free education as well as the introduction of paying pupils in nominally free schools, noting that "[i]n the past few years, the number of paying students in both private and State institutions has been increasing[,]"204 and that " $[c]$ hildren of families in a precarious financial state are compelled to work in order to support themselves, thus diminishing their school attendance and possibilities to study and graduate." ${ }^{205}$ In Romania, constitutional changes in

201. State Programme on Poverty Reduction and Economic Development 2003-2005 (2003), available at http://www.un-az.org/undp/poverty/prspen.pdf (last visited Feb. 5, 2005).

202. "Recently, paid education was also introduced for students who were enrolled . . without passing an entrance examination. Education in private schools, colleges and other private educational institutions is not free of charge." United Nations, Convention on the Elimination of All Forms of Discrimination Against Women; Consideration of Reports Submitted by States Parties Under Article 18 of the Convention on the Elimination of All Forms of Discrimination Against Women - Second and Third Periodic Reports of the States Parties: Republic of Bulgaria If 76, U.N. Doc. CEDAW/C/BGR/2-3 (1994); "[T]he economic difficulties of the State have reflected very unfavourably upon the educational system.... Paid educational and pedagogical services in the State-run schools have risen and are fast becoming a burden for many parents." United Nations, Economic and Social Council; Implementation of the International Covenant on Economic, Social and Cultural Rights - Third Period Reports Submitted by States Parties Under Articles 16 and 17 of the Covenant in Accordance With the Programmes Established by Economic and Social Council Resolution 1988/4-Addendum: Bulgaria If 310 , U.N. Doc. E/1994/104/Add.16 (1996). [hereinafter Third Periodic Reports: Bulgaria]

203. Third Periodic Reports: Bulgaria, supra note 202, at II 280 ("Of particular importance is the provision ... whereby each and every citizen has the right to choose his/her school and type of education in accordance with his/her own preferences and possibilities.").

204. United Nations, Convention on the Rights of the Child, Committee on the Rights of the Child; Consideration of Reports Submitted by States Parties Under Article 44 of the Convention-Initial Reports of States Parties Due in 1995-Addendum: Republic of Moldova II 298, U.N. Docs. CRC/C/28/Add.19 (2002).

205. Id. at II 294. 
November 2003 have altered the educational landscape by replacing the previous sole reference to public education, which should be free, with a provision that said that state, private, and religious schools exist in parallel, and only state education should remain free. The extent of free education is, however, to be specified by further legislation. This legislation may or may not respond to the plea of the Committee on the Rights of the Child to the government to "[m]ake every effort to ensure that compulsory education, and possibly secondary education, is free for all children." 206

In Bosnia and Herzegovina, direct charges in secondary education were successfully challenged by the ombudsman as a human rights violation. ${ }^{207}$ While no tuition fees are charged in primary education, "many cannot afford the cost of textbooks and other materials, and extra-curricular activities are not subsidised." 208 As the Special Representative of the Commission on Human Rights has noted, "excessive out-of-pocket expenses and costs associated with enrollment militate against access to education." 209 Likewise, in the Republic of Macedonia, there is a general constitutional guarantee of free primary education, but it is also

206. United Nations, Convention on the Rights of the Child, Committee on the Rights of the Child; Consideration of Reports Submitted by States Parties Under Article 44 of the Convention - Concluding Observations - Addendum: Romania If 53, U.N. Doc. CRC/C/15/ Add.199 (2003).

207. The Ombudsmen abolished payment of school fees for secondary schools[.] In some of the Cantons enrollment fees were introduced for secondary education. Schools steering boards, upon proposal of directors, determined levels of the fees and they varied from 20 to $50 \mathrm{KM}$. Pupils and their parents lodged complaints with the ombuds-institution and the Ombudsmen issued recommendation ... immediately to stop collection of the fees and to return money to pupils. This recommendation sprang from direct violation of the Law on Secondary Education and article 28 of the Convention on the Rights of the Child, according to which "right to education shall be recognized and made accessible to any child," which is not the case if the fees are introduced.

Ombudsman Institution of the Federation of Bosnia and Herzegovina, Report on Human Rights Situation in the Federation of Bosnia and Herzegovina for 2001, available at http://www.bihfedomb.org/eng/reports/2001/rpt2001 main.htm (last visited Feb. 5, 2005).

208. Bosnia and Herzegovina, National Report on Follow-up to the World Summit for Children 10, (2000), at http://www.unicef.org/bosnia/Download/edr-all.pdf (last visited Feb. 5, 2005).

209. United Nations, Economic and Social Council; Question of the Violations of Human Rights and Fundamental Freedoms in any Part of the World: Situation of Human Rights in Parts of South-Eastern Europe II 18, U.N. Doc. E/CN.4/2003/38 (2003). 
confined to tuition. ${ }^{210}$ The government referred to nongovernmental organization (NGO) comments in its own report, and these comments emphasized that "free education in primary schools is ... only of a declarative character." 211 As elsewhere, minorities, especially the Roma, find themselves victimized by economic exclusion. ${ }^{212}$

In Kyrgyzstan, the right to free education was prolonged in 1997 to encompass secondary, as well as primary education. However, the government acknowledged in 1999 that "the State is short of the resources it needs to keep the schools fully funded[;]" therefore "families are having to spend more on their children's education." 13 While official sources do not acknowledge that schools charge parents for the education of their children, NGO sources do. ${ }^{214}$ Tajikistan has reported that

210. United Nations, Convention on the Rights of the Child, Committee on the Rights of the Child; Consideration of Reports Submitted by States Parties Under Article 44 of the Convention - Initial Report of States Parties Due in 1993-Addendum: The Former Yugoslav Republic of Macedonia II 189, U.N. Doc. CRC/C/8/Add.36 (1997) ("Although primary education is free of charge and is funded through the budget of the Republic of Macedonia, the expenses for textbooks, reference literature, school materials and equipment are paid by the students, i.e. by their parents."); see also id. at II $20,188$.

211. Id. at $\mathbb{I} 190$.

212. Cf.id. at $\mathbb{I} 201$.

213. United Nations, Convention on the Rights of the Child, Committee on the Rights of the Child; Consideration of Reports Submitted by States Parties Under Article 44 of the Convention - Initial Report of States Parties Due in 1996-Addendum: Kyrgyzstan Il 206 , U.N. Doc. CRC/C/41/Add.6 (1999); see also id. at II 205; United Nations, Economic and Social Council; Implementation of the International Covenant on Economic, Social and Cultural Rights - Initial Reports Submitted by States Parties Under Articles 16 and 17 of the Covenant - Addendum: Kyrgyzstan f1 217-218, U.N. Doc. E/1990/5/Add.42 (1999).

214. Officially, education is free (Law of Education and Constiturion of the Kyrgyz Republic). Nevertheless, every year, education departments issue decrees on maximum annual education fee to be paid by parents (usually it is an average of one month minimum wage (about 100 soms); some categories have benefits). It is noted, governmental schools charge fees more than the maximum amount fixed by decree where payment is compulsory. As a rule, no receipts are issued. According to questionnaire review, the average amount charged per child is $300-500$ soms per year and may go beyond 1000 soms. Money is being charged for school building repairs, textbooks, training (monthly), presents for teachers and Principal, etc. Schools become too expensive for many families.... [T] The number of children not attending school is much higher than that in official statistics. Attendance figures are mostly under-reported due to financial and prestige pressure upon school administrators and teachers to maintain high official attendance figures.

NGO Commentaries to the Initial Report of the Kyrgyz Republic on The UN Convention on the Rights of the Child, available at http:/www.crin.org/docs/resources/treaties/crc.24/kyrgystanNGOreport.pdf (last visited Feb. 5, 2005). 
education should be free as the law mandates, but "[o]wing to the pressure of the economic problems of the transitional period and the implementation of market reforms, the actual means available to State bodies to provide children with the opportunity to obtain the necessary education have diminished." ${ }^{15}$ This has created a widespread, but undocumented, practice of levying charges for public schooling and the consequent exclusion of poor children from education.

\section{Middle East and North Africa}

The commitment to free education is reflected in the legal guarantees in all countries in the Middle East and North Africa with the sole exception of Djibouti, as Table 6 shows. As Table 6 also shows, the guarantee of free education has been translated into practice in the majority of countries. Direct charges exist in six out of nineteen countries. In Sudan, education is a casualty of warfare. Although the government reported an attempt to introduce free basic education in 2001, it also acknowledged that education was not free. ${ }^{216}$ It has stated that "voluntary appreciated popular support ... cover[s] more than $50 \%$ of the basic education budget." 217 Also, education is not free in Israel:

Parents are required to purchase books and school supplies for their children, and sections $6-8$ of the law allow a local authority to charge fees for services provided to pupils. In addition to mandatory fees, the school is authorized to collect optional fees for special services, if these are approved by a parents' $[$ sic $]$ committee. ${ }^{218}$

215. United Nations, Convention on the Rights of the Child, Committee on the Rights of the Child; Consideration of Reports submitted by States Parties Under Article 44 of the Convention-Initial Reports of States Parties Due in 1995-Addendum: Tajikistan II 4 , U.N. Doc. CRC/C/28Add.14 (1998).

216. United Nations, Convention on the Rights of the Child, Committee on the Rights of the Child; Consideration of Reports Submitted by States Parties Under Article 44 of the Convention-Periodic Reports of States Parties Due in 1997-Adpendum: Sudan II 279 , 283, 325 U.N. Doc. CRC/C/65/Add.17 (2001).

217. Republic of Sudan, Ministry of Education and General Education, General Division of Assessment and Examinations, Report on Sudan, Education for All, The Year 2000 Assessment, 1999, at http://www2.unesco.org/wef/countryreports/sudan/contents.html (last visited Feb. 5, 2005).

218. United Nations, Convention on the Rights of the Child, Committee on the Rights of the Child; Consideration of Reports Submitted by States Parties Under Article 44 of the Convention-Periodic Reports of States Parties Due in 1993-Addendum: Israel If 910 , U.N. Doc. CRC/C/8/Add.44 (2002). 
Primary education is, according to the self-assessment by governments in their reports required by human rights treaties, free, compulsory, and allencompassing in Algeria, ${ }^{219}$ Bahrain, ${ }^{220}$ Kuwait, ${ }^{221}$ Libya, ${ }^{222}$ Saudi Arabia, ${ }^{223}$ and Tunisia. ${ }^{224}$ In the United Arab Emirates, however, the government has reported that education is free, but then states that charitable organizations pay some education costs. ${ }^{225}$ In Oman, education is reportedly free but not compulsory. ${ }^{226}$

219. United Nations, Economic and Social Council; Implementation of the International Covenant on Economic, Social and Cultural Rights-Second Periodic Reports Submitted by States Parties Under Articles 16 and 17 of the Covenant - Addendum: Algeria 19161 , 173-74, U.N. Doc. E/1990/6/Add.26 (2000).

220. United Nations, Convention on the Rights of the Child, Committee on the Rights of the Child; Consideration of Reports Submitted by States Parties Under Article 44 of the Convention - Initial Reports of States Parties Due in 1994-Addendum: Bahrain 19 II 249 50, U.N. Doc. CRC/C/11/Add.24 (2001).

221. "Although education is compulsory only at the primary and intermediate levels, it is provided free of charge up to the end of the university or equivalent level." UNITED NATIONS, CoNvention on the Rights of the Child, Committee on the Rights of the Child; Consideration of Reports Submitted by States Parties Under Article 44 of the Convention-Initial Reports of States Parties Due in 1993-Addendum: Kuwait Il 168, U.N. Doc. CRC/C/8/Add.35 (1996).

222. United Nations, Convention on Rights of the Child, Committee on the Rights of the Child; Consideration of Reports Submitted by States Parties Under Article 44 of the Convention - Initial Reports of States Parties Due in 1993: Libyan Arab Jamahiriya II 1 222, 238, 246-47, U.N. Doc. CRC/C/8/Add.35 (1996).

223. See United Nations, Convention on Rights of the Child, Committee on the Rights of the Child; Consideration of Reports Submitted by States Parties Under Article 44 of the Convention-Initial Report of Saudi Arabia Due in 1998-Addendum If 143, U.N. Doc. CRC/C/61/Add.2 (2000).

224. United Nations, Convention on Rights of the Child, Committee on the Rights of the Childi; Consideration of Reports Submitted by States Parties Under Article 44 of the Convention - Periodic Reports of States Parties Due in 1999-Addendum: Tunisia III 494, 496, U.N. Doc. CRC/C/83/Add.1 (2001).

225. United Nations, Convention on the Rights of the Child, Commitree on the Rights of the Child; Consideration of Reports Submitted by States Parties Under Article 44 of the Convention-Initial Reports of States Parties Due in 1999-Addendum: United Arab Emirates II 4 494, 496, U.N. Doc. CRC/C/78/Add.2 (2001).

226. "Primary education is free of charge and available to all children in Oman willing to enrol." United Nations, Convention on the Rights of the Child, Committee on the Rights of the Child; Consideration of. Reports Submitted by States Parties Under Article 44 of the Convention - Initial Reports of States Parties Due in 1999-Addendum: Oman Il 172, U.N. Doc. CRC/C/78/Add.1 (2002). 
Lebanon reported making primary education free and compulsory by law in 1998, but admitted in the same report that primary education was actually not made free. ${ }^{227}$ Its subsequent report described the consequences:

[I]n the event that the current trends in the performance of the education system continue, in particular the high rates of school drop-out in favour of child employment, along with the high cost of education, especially private school fees, and the limited intake capacity of State schools, it can be predicted that the phenomenon of illiteracy and semi-illiteracy among children, both as an absolute number and as percentages of the overall age group, will worsen. $^{228}$

227. “On 16 March 1998, Decree No. 686 was promulgated to make primary education compulsory and free. It contained a single article, as follows: . . 'Education shall be free and compulsory in the first primary stage and is a right of every Lebanese person of primary school age." UNITED Nations, Convention on the Rights of the Child, Committee on the Rights of the Child; Consideration of Reports Submitted by States Parties Under Article 44 of the Convention-Initial Reports of States Parties Due in 1998-Addendum: Lebanon II 191, U.N. Doc. CRC/C/78/Add. 8 (2000).

The law also provides for free primary education by either of two methods: the first is through State schools and the second is through primary schools belonging to the private sector which receive financial support from the State. . . Accordingly, the following types of educational institutions co-exist in the Lebanese education system: (a) [Official educational institutions]: From kindergarten to university, these are State institutions which are free in principle (the pupil or student pays registration fees and sometimes other fees in addition). (b) [Private non-fee-paying institutions]: These exist only at the primary stage. ... In these schools, the pupil pays registration fees and other miscellaneous costs which vary from school to school. (c) [Private fee-paying educational institutions]: ... [T] [Te pupils or students in such institutions pay annual fees which are fixed by the administration concerned and vary from one institution to another.

Id. at II 195. "In actual fact, education is not free, even for families who register their children in State schools or in private non-fee-paying schools." Id. at II 199.

228. United Nations, Convention on the Rights of the Child, Committee on the Rights of the Child; Consideration of Reports Submitted by States Parties Under Article 44 of the Convention-Second Periodic Reports of States Parties Due in 1998-Addendum: Lebanon II 233, U.N. Doc. CRC/C/70/Add.8 (2000). 
Table 6: Middle East and North Africa

\begin{tabular}{|c|c|c|c|c|}
\hline \multirow[t]{2}{*}{ Country } & \multicolumn{2}{|c|}{$\begin{array}{l}\text { Legal guarantee } \\
\text { of free education }\end{array}$} & \multicolumn{2}{|c|}{$\begin{array}{l}\text { School fees } \\
\text { charged }\end{array}$} \\
\hline & Yes & No & Yes & No \\
\hline Algeria & 1 & & & $\sqrt{1}$ \\
\hline Bahrain & 1 & & & $\sqrt{1}$ \\
\hline Djibouti & & $\sqrt{ }$ & 1 & \\
\hline Egypt & $\sqrt{ }$ & & $\sqrt{ }$ & \\
\hline Iran & $\sqrt{1}$ & & $\sqrt{ }$ & \\
\hline Israel & 1 & & $\sqrt{ }$ & \\
\hline Jordan & 1 & & & $\sqrt{1}$ \\
\hline Kuwait & 1 & & & 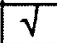 \\
\hline Lebanon & $\sqrt{ }$ & & $\checkmark$ & \\
\hline Libya & 1 & & & $\sqrt{1}$ \\
\hline Morocco & $\sqrt{ }$ & & & $\sqrt{1}$ \\
\hline Oman & 1 & & & $\sqrt{1}$ \\
\hline Qatar & $\sqrt{ }$ & & 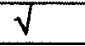 & \\
\hline Saudi Arabia & 1 & & & $\sqrt{2}$ \\
\hline Sudan & $\sqrt{ }$ & & $\sqrt{ }$ & \\
\hline Syria & $\sqrt{ }$ & & & $\sqrt{ }$ \\
\hline Tunisia & $\sqrt{ }$ & & & $\sqrt{ }$ \\
\hline United Arab Emirates & $\sqrt{3}$ & & $\sqrt{ }$ & \\
\hline Yemen & $\sqrt{ }$ & & $\sqrt{ }$ & \\
\hline
\end{tabular}

In Qatar, education should be free according to the law, but the government has ack nowledged that charges are imposed in some cases. ${ }^{229}$ The adoption of a law in 2001, which guarantees "free and compulsory education for all children in the State[,]" may result in the abolition of these various fees. ${ }^{230}$

229. "Education is basically free of charge, its cost being met from the State budget with the exception of some minor fees which were recently imposed due to the difficult economic circumstances that the State has faced in the last few years. These fees, consisting of nominal amounts for educational services provided, are charged in respect of the children of foreign residents." UNITED Nations, International Convention on the Elimination of All Forms of Racial Discrimination, Committee on the Elimination of Racial Discrimination; Reports Submitted by States Parties Under Article 9 of the Convention-Twelfth Periodic Reports of States Parties Due in 1999-Addendum: Qatar I 58, U.N. Doc. CERD/C/360/Add.1 (2001).

230. "The Committee [on the Rights of the Child] welcomes the adoption of Law No. 25 of 2001 concerning free and compulsory education for all children in the State party." UNited Nations, Convention on the Rights of the Child, Committee on the Rights of the Child; Consideration of Reports Submitted by States Parties Under Article 44 of the Convention- 
The government of Iran has reported that all children age six to ten should have been encompassed by primary education by the end of 1999, which should also be free. ${ }^{231}$ Nonetheless, net enrollment reached only 74 percent in $2000 .{ }^{232}$ In Morocco, universalizing primary education was planned for $2002 .{ }^{233}$ Lowering direct costs of education was identified as a priority owing to large numbers of children who start school but drop out early. In Yemen, there is a constitutional guarantee of the right to education, ${ }^{234}$ which has not yet been implemented or, least of all, enforced. Charges are widespread and the government reported in 2002 that it only planned to "[e]xempt girls in rural and remote areas from payment of school fees."235

Primary education has not been universalized in Djibouti, ${ }^{236}$ and the right to education is not guaranteed as yet. In Jordan, education should be free of charge at

Concluding Observations of the Committee on the Rights of the Child-Adpendum: Qatar I 3, U.N. Doc. CRC/C/15/Add.163 (2001). The changes this law will make in education depend on its interpretation and enforcement, neither of which are known as yet.

231. See United Nations, Convention on the Rights of the Child, Committee on the Rights of the Child; Consideration of Reports Submitted by States Parties Under Article 44 of the Convention - Initial Reports of States Parties Due in 1996-Addendum: Islamic

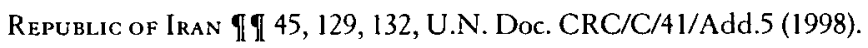

232. See Gender and Education for All, The Leap to Equality, supra note 14, at 333, Table 5.

233. Primary education was originally designed for children ages $7-13$ and in 1985 extended to 9 years. Thus, education should have covered all children ages $7-13$ by 2002 , and all children ages 7-16 by the year 2008. United Nations, Convention on the Rights of the Child, Committee on the Rights of the Child; Consideration of Reports Submitted by States Parties Under Article 44 of the Convention-Second Periodic Reports of States Parties Due in $2000-$ Addendum: Morocco If 456, U.N. Doc. CRC/C/93/Add.3 (2003).

234. The Yemen Constitution "stipulates that the State, together with society, must contribute to the provision of education .... [It] further stipulates that all citizens have a right to education which the State must safeguard, in accordance with the law, by ... making basic education free." United Nations, Convention on the Rights of the Child, Committee on the Rights of the Child; Consideration of Reports Submitted by States Parties Under Article 44 of the Convention-Second Periodic Reports of States Parties Due in 1998-Addendum: Yemen 1 152, U.N. Doc. CRC/C/70/Add.I (1998); see also Yemen Const. art. 37.

235. United Nations, Economic and Social Council; Substantive Session of 2002- Implementation of the International Covenant on Economic, Social and Cultural RightsInitial Reports Submitted by States Parties Under Articles 16 and 17 of the CovenantAdpendum: Yemen II 154, U.N. Doc. E/1990/5/Add.54 (2002).

236. The government reported in 1998 that "[j]ust under 50 percent of school-age children are admitted to primary school, and almost 80 percent of those pupils do not pursue their studies at secondary school." United Nations, Convention on the Rights of the Child, Committee on the Rights of the Child; Consideration of Reports Submitted by States Parties Under Article 44 of the Convention-Initial Reports of States Parties Due in 1993: Republic of Djıboutı If 116, U.N. Doc. CRC/C/8Add.39 (1998). 
government schools for its citizens (thus excluding noncitizens who include large numbers of Palestinian refugees), but the government has added the clause "within the limits of its resources." Education is compulsory to the age of seventeen, but not all children finish school, often because of poverty. ${ }^{237}$ In Syria, education should be free and all-encompassing according to the law, but the government admitted in 2002 that this was not the case. ${ }^{238}$ Egypt has reported "that all children are entitled to education during the first, compulsory stage, that education is provided free of charge and that children who must work have an opportunity to catch up[,]"239 but the available information shows that "must" is not translated into practice.

\section{E. South America and the Caribbean}

In this region, the commitment to ensuring free education is reflected in the high degree of correspondence between formal guarantees and government policies. In countries as different as Costa Rica ${ }^{240}$ and Cuba, ${ }^{241}$ free and all-encompass-

237. "According to the Constitution, the State ... undertakes to provide education within the limits of its resources, primary education being compulsory for Jordanians and free of charge at government schools." United Nations, Convention on the Rights of the Child, Committee on the Rights of the Child; Consideration of Reports Submitted by States Parties Under Article 44 of the Convention-Periodic Reports of States Parties Due in 1998: Jordan II 11, U.N. Doc. CRC/C/70/Add.4 (1999); see also Jordan Const. art. 6(ii), § 20.

238. "In spite of the efforts made to enforce the provisions of the Compulsory Education Act ... a number of children of compulsory school age, particularly girl children, are still not being enrolled in, or drop out of, school, for social, economic or cultural reasons." UNited Nations, Convention on THE Rights of the Child, Committee on the Rights of the Child; Consideration of Reports Submitted by States Parties Under Article 44 of the Convention - Periodic Reports of States Parties Due in 2000-Addendum: Syrian Arab Republic II 31, U.N. Doc. CRC/C/93/Add.2 (2002). "[S]chools at all stages of education continue to suffer from the shortage of material and technological resources required to improve their health and environmental and educational situation." Id. at II 153.

239. United Nations, Convention on the Rights of the Child, Committee on the Rights of the Child; Consideration of Reports Submitted by States Parties Under Article 44 of the Convention-Periodic Reports of States Parties Due in 1997-Addendum: Egypt Il 138, U.N. Doc. CRC/C/65/Add.9 (1999).

240. Costa Rica Const. art. 78; see also United Nations, Convention on the Rights of the Child, Committee on the Rights of the Child; Consideration of Reports Submitted by States Parties Under Article 44 of the Convention - Periodic Reports of States Parties Due in 1997-Addendum: Costa Rica If 61, U.N. Doc. CRC/C/65/Add.7 (1998).

241. United Nations, Economic and Social Council, Committee on Human Rights; Question of the Violation of Human Rights and Fundamental freedoms in Any Part of the World, With Particular Reference to Colonial and Other Dependent Countries and Territories If 50, U.N. Doc. E/CN.4/1994/51 (1994). 
ing education has been attained through profoundly different models. The constitutional models vary, and Grenada, St. Vincent and Grenadines, and Trinidad and Tobago do not guarantee free and compulsory education ${ }^{242}$ Also, education is declared to be a right, ${ }^{243}$ a duty, or both. ${ }^{244}$ As Table 7 shows, there is a correspondence between the absence of a legal guarantee of free education and the charging of fees, although there are exceptions.

242. In Grenada, "the Education Act . . . stipulates that pupils be admitted to all government schools, assisted primary and all age schools free of charge." United Nations, Convention on the Rights of the Child, Committee on the Rights of the Child; Consideration of Reports Submitted by States Parties Under Article 44 of the Constitution; Initial Reports of States Parties Due in 1992-Addendum: Grenada II 125, U.N. Doc. CRC/C/3/Add.55 (1997). In Trinidad and Tobago, "[r]he right to education is not enshrined in the Constitution." UNIted Nations, Economic and Social Council; Implementation of the International Covenant on Economic, Social and Cultural Rights-Second Periodic Reports Submitted by States Parties Under Articles 16 and 17 of the Covenant: Trinidad and Tobago 19 274-75, 277, U.N. Doc. E/1990/6/ Add.30 (2000). In St. Vincent and the Grenadines, the law mandates compulsory education but there is no provision on its length, nor has there "yet been a move to institute compulsory education in the country," which is explained in part by poverty. "[S]ome parents have insufficient income to provide food for the children to take to school or to pay for transportation." United Nations, Convention on the Rights of the Child, Committee on the Rights of the Child; Consideration of Reports Submitted by States Parties Under Article 44 of the Convention - Initial Reports of States Parties Due in 1995-Addendum: Saint Vincent and the Grenadines $\mathbb{3} 313$, U.N. Doc. CRC/C/ 28/Add. 18 (2001); see also United Nations, Economic and Social Council, Committee on Economic, Social and Cultural Rights; Consideration of Reports Submitted by States Parties Under Articles 16 and 17 of the Covenant-Concluding Observations-Addendum: Saint Vincent and the Grenadines II 27, U.N. Doc. E/C.12/1/Add.21 (1997).

243. In Uruguay, "the Constitution in force since 1967 recognizes education as one of the priority human rights and it makes this recognition manifest by proclaiming the freedom of education, including the right to teach, the right to learn and the right to establish and operate teaching institutions. The compulsory and free status of primary, secondary, agrarian, technical and higher education are the pillars on which the country's whole education system rests." UNITED Nations, Convention on the Rights of the Child, Committee on the Rights of the Child; Consideration of Reports Submitted by States Parties Under Article 44 of the Convention-Initial Reports of States Parties Due in 1992-Addendum: Uruguay II 231, U.N. Doc. CRC/C/3/ Add.37 (1995). Under the Venezuelan Constitution, "[e]veryone has the right to an education. The State shall create and maintain schools, institutions and services sufficiently endowed to ensure access to education and to culture, with no limitations other than those deriving from the vocation and from aptitude. Education provided by public institutions shall be free in all cycles. However, the law may establish exceptions with respect to higher and special education in the case of persons with means." United Nations, Economic and Social Council; Substantive Session of 1999-Implementation of the International Conenant on Economic, Social and Cultural Rights - Second Periodic Reports Submitted by States Parties Under Articles 16 and 17 of the Covenant: Venezuela II 307, U.N. Doc. E/1990/6/Add.19 (1999).

244. In El Salvador, "[a]ll inhabitants of the Republic have the right and the duty to receive preschool and basic education that equips them to assume their role as useful citizens." UNITED 
The economic crises in many countries in the region have affected education. In Argentina, the government reported in 2002 that free primary education had been universalized and, although the responsibility for education had been decentralized, "the national State must provide free compulsory education for all the country's inhabitants." 245 Brazil noted in 2001 that it "needed to overcome a number of major barriers comprising fiscal adjustment programmes and a series of international financial crises before it could implement wide-ranging social policies." 246 Honduras has pointed out that "the Government has taken a number of economic structural adjustment measures which have infringed or diminished in one way or another the rights recognized in the Covenant [on Economic, Social and Cultural Rights]; the effect has been further to impoverish the al ready disadvantaged groups." ${ }^{247}$ Children pay the highest price. Their lack of access to education, coupled with persistently high illiteracy levels, often leave self-employment as the only survival strategy for those without education. ${ }^{248} \mathrm{Ja}$ maica has reported that budgetary stringency has confined free education to pri-

Nations, Congention on the Rights of the Child, Committee on the Rights of the Child; Consideration of Reports Submitted by States Parties Under Article 44 of the Convention-Initial Reports of States Parties Due in 1992-Addendum: El Salvador II 28, U.N. Doc. CRC/C/3/Add.9 (1993); United Nations, Convention on the Right of the Child, Committee on the Rights of the Child; Consideration of Reports Submitted by States Parties Under Article 44 of the Convention - Initial Reports of States Parties Due in 1992-Addendum: Guatemala II 99, U.N. Doc. CRC/C/3/Add.33 (1995); see also id. at 160.

245. United Nations, Convention on the Rights of the Child, Committee on the Rights of the Child; Consideration of Reports Submitted by States Parties Under Article 44 of the Convention-Periodic Reports of States Parties Due in 1998-Addendum: Argentina II 423, U.N. Doc. CRC/C/70/Add.10; see also id. at II 425, 463.

246. United Nations, Economic and Social Council; Substantive Session of 2002Implementation of the International Conenant on Economic Social and Cultural Rights-Initial Reports Submitted by States Parties Under Articles 16 and 17 of the Covenant-Addendum: Brazil II 18, U.N. Doc. E/1990/5/Add.53 (2001).

247. United Nations, Economic and Social Council; Substantive Session of 1998 Implementation of the International Covenant on Economic, Social and Cultural Rights-Initial Reports Submitted by States Parties Under Articles 16 and 17 of the Covenant-Addendum: Honduras 1 36, U.N. Doc. E/1990/5/Add.40 (1998).

248. See generally United Nations, Convention on the Rights of the Child, Committee on the Rights of the Child; Consideration of Reports Submitted by States Parties Under Article 44 of the Convention-Periodic Reports of States Parties Due in 1997-Adpendum: Honduras, U.N. Doc. CRC/C/65/Add.2 (1998). 
mary schooling alone. ${ }^{249}$ The low quality of primary education and the absence of free secondary education have resulted in "an illiteracy rate of 13.5 percent and 31 percent among the 15-19 age cohort, and primary school leavers, respectively." 250 Poverty has been a defining feature of Nicaragua's public education. Although primary education should be free, "it has become necessary to ask parents to make a modest contribution themselves, the problem becoming critical where the parents are very poor and cannot afford this, especially when they have several children of school age." 251 In Panama, all pre-university education should be free but the budgetary resources necessary to make this come true have apparently not been deployed. ${ }^{252}$ In Paraguay, the government acknowledged in 1993

249. "The cost of education makes it difficult to reach the desirable goal ... to make secondary education available and accessible to every child.... [T] he national economy has made it necessary for Government to embark on a cost-sharing venture, in which resources are being redirected from secondary to primary level." United Nations, Committee on the Rights of the Child; Consideration of Reports Submitted by States Parties Under Article 44 of the Convention-Initial Reports of States Parties Due in 1993-Addendum: Jamaica II 69, U.N. Doc. CRC/C/8/Add.12 (1994).

250. United Nations, Economic and Social Council; Substantive Session of 2001-Implementation of the International Covenant on Economic, Social and Cultural Rights - Second Periodic Reports Submitted by States Parties Under Articles 16 and 17 of the Covenant - Adpendum: Jamaica II 148, U.N. Doc. E/1990/6/Add.28 (2001).

251. United Nations, Committee on the Rights of the Child; Consideration of Reports Submitted by States Parties Under Article 44 of the Convention-Initial Reports of States Parties Due in 1992-Addendum: Nicaragua Il 40, U.N. Doc. CRC/C/3/Add.25 (1994).

252. The Constitution of Panama, in Article 91, states that "[f]ree education shall entail the State's obligation to furnish students with all the equipment necessary for their instruction until they complete their basic general education. Free education shall not preclude the establishment of a tuition fee payable at the non-compulsory levels." United Nations, Convention on the Rights of the Child, Committee on the Rights of the Child; Consideration of Reports Submitted by States Parties Under Article 44 of the Convention-Initial Reports of States Parties Due in 1993-Addendum: Panama II 68, U.N. Doc. CRC/C/8/Add.28 (1995) (quoting Panama Const. art. 91). "It must also be stressed that the State is required to provide pupils with all necessary equipment during their basic general education." Id. at 165. "[T]he Committee is concerned about the inadequacy of resources allocated to address the problems of primary and secondary education." United Nations, Economic and Social Council, Committee on Economic, Social and Cultural Rights; Consideration of Reports by States Parties Under Articles 16 and 17 of the Covenant-Concluding Observations of the Committee on Economic, Social and Cultural Rights-Addendum: Panama II 23, U.N. Doc. E/C.12/1/ Add.64 (2002). 
Table 7: South America and the Caribbean

\begin{tabular}{|c|c|c|c|c|}
\hline \multirow[t]{2}{*}{ Country } & \multicolumn{2}{|c|}{$\begin{array}{l}\text { Legal guarantee } \\
\text { of free education }\end{array}$} & \multicolumn{2}{|c|}{$\begin{array}{l}\text { School fees } \\
\text { charged }\end{array}$} \\
\hline & Yes & No & Yes & No \\
\hline Antigua and Barbuda & 1 & & $\sqrt{ }$ & \\
\hline Argentina & 1 & & & J \\
\hline Barbados & $\sqrt{2}$ & & & $\sqrt{ }$ \\
\hline Belize & $\sqrt{1}$ & & & $\sqrt{ }$ \\
\hline Bolivia & $\sqrt{ }$ & & & $\sqrt{ }$ \\
\hline Brazil & J & & & $\sqrt{ }$ \\
\hline Chile & 1 & & & $\sqrt{ }$ \\
\hline Colombia & & $\sqrt{ }$ & $\checkmark$ & \\
\hline Costa Rica & $\sqrt{1}$ & & & $\checkmark$ \\
\hline Cuba & 1 & & & $\checkmark$ \\
\hline Dominican Republic & 1 & & & $\sqrt{ }$ \\
\hline Ecuador & $\sqrt{ }$ & & $\sqrt{ }$ & \\
\hline El Salvador & $\sqrt{1}$ & & & $\sqrt{ }$ \\
\hline Grenada & & $\sqrt{ }$ & $\checkmark$ & \\
\hline Guatemala & 1 & & $\checkmark$ & \\
\hline Guyana & $\sqrt{ }$ & & $\checkmark$ & \\
\hline Haiti & & $\sqrt{ }$ & $\sqrt{ }$ & \\
\hline Honduras & 1 & & & $\sqrt{ }$ \\
\hline Jamaica & & $\sqrt{ }$ & T & \\
\hline Mexico & 1 & & & $\sqrt{ }$ \\
\hline Nicaragua & 1 & & $\sqrt{ }$ & \\
\hline Panama & $\sqrt{ }$ & & & $\sqrt{ }$ \\
\hline Paraguay & $\sqrt{ }$ & & $\sqrt{ }$ & \\
\hline $\begin{array}{l}\text { Peru } \\
\text { Peru }\end{array}$ & $\sqrt{ }$ & & 1 & \\
\hline St Kitts and Nevis & $\sqrt{1}$ & & & $\sqrt{ }$ \\
\hline St Lucia & & $\sqrt{ }$ & $\sqrt{ }$ & \\
\hline St Vincent and Grenadines & & $\sqrt{ }$ & $\sqrt{ }$ & \\
\hline Suriname & $\sqrt{1}$ & & $\sqrt{1}$ & \\
\hline Trinidad and Tobago & $\sqrt{1}$ & & $\sqrt{1}$ & \\
\hline Uruguay & $\sqrt{ }$ & & & $\sqrt{ }$ \\
\hline Venezuela & 1 & & & $\sqrt{ }$ \\
\hline
\end{tabular}


that it could not provide free education, ${ }^{253}$ while after the turn of the millennium only the cost of tuition was reportedly assumed by the government. ${ }^{254}$

It is well-known that wealthy, urban populations have much more access to education than poor, rural populations, and that people with disabilities often have none, least of all free of charge. This is vividly illustrated in the reports by Ecuador required under its human rights treaties. In one of these, the government has stated that "[a]ll Ecuadorians have free access to education without discrimination of any kind[,]"255 only to acknowledge in another that "there are problems with discrimination, particularly on the basis of differences in ethnicity, gender or economic status or disabilities." ${ }^{256}$ In Guyana, free education was introduced in 1976. ${ }^{257}$ According to the government's self-assessment, the original model did not work even twenty years later. ${ }^{258}$ In Haiti, public education vir-

253. "The current National Constitution guarantees free education and stipulates that primary education is compulsory. However, in present social conditions it is impossible to enforce this constitutional guarantee, on account of the high cost of living." United Nations, Convention on the Rights of the Child, Committee on the Rights of the Child; Consideration of Reports Submitted by States Parties Under Article 44 of the Convention-Initial Reports of States Parties Due in 1992-Adpendum: Paraguay 1 1 120, U.N. Doc. CRC/C/3/Add.22 (1993).

254. The Committee on the Rights of the Child is "concerned about the continuing poor quality of education [and] the non-tuition costs of compulsory school." UNITED NATIONS, CONvENTION ON the Rights of the Child, Committee on the Rights of the Child; Consideration of Reports Submitted by States Parties Under Article 44 of the Convention-Concluding Observations of the Committee on the Rights of the Child - Addendum: Paraguay II 43, U.N. Doc. CRC/C/15/Add.166(2001).

255. United Nations, International Convention on the Elimination of All Forms of Racial Discrimination, Committee on the Elimination of Racial Discrimination; Reports Submitted by States Parties Under Article 9 of the Convention-Sixteenth Periodic Reports of States Parties Due in 2001-Addendum: Ecuador II 142, U.N. Doc. CERD/C/384/ Add.8 (2002).

256. United Nations, Convention on the Rights of the Child, Committee on the Rights of the Child; Consideration of Reports Submitted by States Parties Under Article 44 of the Convention-Initial Reports of States Parties Due in 1992-Addendum: Ecuador II 74, U.N. Doc. CRC/C/3/Add.44 (1996).

257. "After 1976 a system of free education was introduced from the nursery to the tertiary level by the Government which assumed full responsibility for formal education." UNited Nations, Economic and Social Council; Substantial. Session of 1996-Implementation of the International Covenant on Economic, Social and Cultural Rights - Initial Reports Submitted by States Parties Under Articles 16 and 17 of the Covenant - Addendum: Guyana If 107, U.N. Doc. E/1990/5/Add.27 (1995).

258. While the introduction of a system of free education appeared to work very well for a while, poor administration and unreliable maintenance, among other things, 
tually collapsed, where only 11 percent of schools are public "while the private sector accounts for about 89 percent." 259 In Suriname, "the State is obliged to ... provide free education at all levels[,]" but direct charges are being levied and acknowledged. ${ }^{260}$

In Colombia, the constitutional guarantee of the right to education does not extend to free primary education for all but only for those who cannot afford the cost of education. The United Nations Committee on Economic, Social and Cultural Rights has rejected "the imposition of fees," a practice the Committee considers contrary to the Covenant because it "prevented a number of children from having access to free primary education[,] and ... [the children's] families had to institute legal proceedings in order to obtain such access." ${ }^{261}$ Moreover, direct charges levied on public primary education have prevented its universalization. Bolivia has reported that "education is the highest function of the State" according to its constitution, and free primary education should be ensured to all. ${ }^{262}$ The Committee on Economic, Social and Cultural Rights noted in 2001

caused a general decline to set in causing the education standards of the country to drop significantly. The physical condition of many schools is extremely unsatisfactory with poor sanitary facilities and inadequate or non-existent water supply. Inadequate furniture, a high incidence of vandalism and theft and a shortage of qualified personnel .... are also factors which seriously inhibit the right to education. Id. at \1 120.

259. United Nations, Convention on the Rights of the Child, Committee on the Rights of the Child; Consideration of Reports Submitted by States Parties Under Article 44 of the Convention - Initial Reports of States Parties Due in 1997-Addendum: Haiti 1 1 184, U.N. Doc. CRC/C/51/Add.7 (2002).

260. United Nations, Convention on the Rights of the Child, Committee on the Rights of the Child; Consideration of Reports Submitted by States Parties Under Article 44 of the Convention-Initial Reports of States Parties Due in 1995-Addendum: Suriname 1118 , U.N. Doc. CRC/C/28/Add.11 (1998). "In principle, all levels of education are free of charge. This only applies to tuition, since the State-run schools have a registration fee and the denominational schools ask an annual "parent contribution." Id. at $\$ 124$.

261. United Nations, Economic and Social Council, Committee on Economic, Social and Cultural Rights; Consideration of Reports Submitted by States Parties Under Articles 16 and 17 of the Covenant - Concluding Observations of the Committee on Economic, Social and Cultural Rights-Addendum: Colombia II 27, U.N. Doc. E/C.12/1/Add.74 (2001).

262. United Nations, Convention on the Rights of the Child, Committee on the Rights of the Child; Consideration of Reports Submitted by States Parties Under Article 44 of the Convention-Periodic Reports of States Parties Due in 1997-Addendum: Bolivia If 274 , U.N. Doc. CRC/C/65/Add.1 (1997). 
that "70 percent of children under nine years of age do not attend school[, ]"263 often because there simply are no schools in rural areas. In urban areas, children may need to work rather than go to school, as the government itself acknowledged in $1997 .{ }^{264}$ In Peru, an immensely complicated system was set up with the aim of making education free. ${ }^{265}$ Despite the explicit constitutional guarantee of free education in state schools, cases have been reported of the charging of fees and challenges to them. ${ }^{266}$

Parallel systems of public and private and free and for-fee schools exist in all countries in the region except Cuba. In those countries, the duality of free education provided by the state and for-fee private education was introduced

263. United Nations, Economic and Social Council, Committee on Economic, Social and Cultural Rights; Consideration of Reports Submitted by States Parties Under Articles 16 and 17 of the Covenant - Concluding Observations of the Committee on Economic, Social and Cultural Rights - Adpendum: Bolivia II 25, U.N. Doc. E/C.12/1/Add.60 (2001).

264. The National Diagnostic Study of Bolivian Yourh showed that dropping out begins in adolescence (at 14 in the urban and 12 in the rural areas). There are two main reasons, namely, in the cities the need to work and in the rural areas the inadequacy and poor quality of the supply ... factors which the educational reforms are intended to address.

United Nations, Convention on the Rights of the Child, Committee on the Rights of the Child; Consideration of Reports Submitted by States Parties Under Article 44 of the Convention-Periodic Reports of States Parties Due in 1997-Addendum: Bolivia II 81, U.N. Doc. CRC/C/65/Add.1 (1997) (citation omitted).

265. Early, primary and secondary education is compulsory and guaranteed as a right established by the 1993 Peruvian Political Constitution, which specified that education is provided without charge at State institutions at the various levels, including higher education at public universities. ... In addition, the 1993 Political Constitution states that "in order to ensure the widest choice in the educational offering and to benefit persons unable to meet the cost of their education, the law determines the method of subsidizing private education in every form, including community and cooperative modalities."

United Nations, Convention of the Rights of the Child, Committee on the Rights of the Child; Consideration of Reports Submitted by States Parties Under Article 44 of the Convention-Periodic Reports of States Parties Due in 1997-Addendum: Peru 11 II 658-659, U.N. Doc. CRC/C/65/Add.8 (1998).

266. There have been cases in which children and/or adolescents are removed from school without justification, for example because their parents cannot pay the enrolment fees or the dues of the Parents' Association, in State schools. In such cases, the Ombudsmen for Children and Adolescents and the family procurators intervene, arranging for the child to be enrolled immediately and informing the Administrative Office of the Ministry of Education.

Id. at I 164 . 
through legal or constitutional changes. In Mexico, "education provided by the State [continues to] be free" but the constitutional amendments in 1993 established that "[p]rivate individuals may provide education of all types and modalities."267 Further legal reform that same year "encourage[d] the increased participation of private individuals in the funding of education." 268 Free education is confined to the public system. In Belize, the majority of children attend religious schools, which charge fees, and thus do not benefit from free education. ${ }^{269}$ In Guatemala, the government acknowledged in 2002 that primary education was not universalized, citing a wide range of factors from budgetary limitations to the range of indigenous languages in the country. ${ }^{270}$ Also, it placed limitations on the extension of free education. "[E]ducation provided by the State," ${ }^{271}$ which should be free, has been supplemented, or perhaps replaced, by educational cooperatives. ${ }^{272}$

The right to education is, similarly to other regions, often confined to citizens. In Antigua and Barbuda, the government has acknowledged that "eco-

267. United Nations, Economic and Social Council; Substantive Session of 1998-Implementation of the International Covenant on Economic, Social and Cultural Rights Third Periodic Reports Submitted by States Parties Under Articles 16 and 17 of the Covenant in Accordance With the Programmes Established by Economic and Social Council Resolution 1988/4 - Addendum: Mexico If 410, U.N. Doc. E/1994/104/Add.18 (1998).

268. Id. at II 26.

269. "[W]ithin the primary education system of 274 schools, Catholic schools serve 62 percent of all pupils, government schools 10 per cent, Anglican 10 percent and Methodist 8 per cent, 30 of these schools are privately run." United Nations, Convention on the Rights of the Child, Committee on the Rights of the Child; Consideration of Reports Submitted by States Parties Under Article 44 of the Convention - Initial Reports of States Parties Due in 1992Addendum: Belize II 229, U.N. Doc. CRC/C/3/Add.46 (1997).

270. United Nations, Economic and Social Council; Substantive Session of 2002-Implementation of the International Covenant on Economic, Social and Cultural Rights-Second Reports Submitted by States Parties Under Articles 16 and 17 of the CovenantAdpendum: Guatemala II 222, U.N. Doc. E/1990/6/Add.34 (2002).

271. "[T] ants and that no charge shall be made for education provided by the State." United NATIONS, Convention on the Rights of the Child, Committee on the Rights of the Child; Consideration of Reports Submitted by States Parties Under Article 44 of the Convention - Initial Reports of States Parties Due in 1992-Addendum: Guatemala 1 260, U.N. Doc. CRC/C/3/ Add. 33 (1995).

272. "The education cooperatives programme aims to provide comprehensive basic education to all Guatemalans in order to help improve people's overall level of education and information by providing education at accessible prices." UNited NATIONs, supra note 270, at 115. 
nomic migrants" do not enjoy free schooling and have to purchase education. ${ }^{273}$ A person's financial status profoundly affects his or her education in the Dominican Republic. A large proportion of children attend private schools, ${ }^{274}$ and the difference in the impact that the cost of education has on the finances of rich and poor families is significant. ${ }^{275} \mathrm{~A}$ precedential case against the Dominican Republic, decided by the Inter-American Commission on Human Rights, affirmed that all children, even noncitizens, have the right to education. ${ }^{276}$ Otherwise, the provision that primary education is both free and compulsory ${ }^{277}$ would have continued to permit the exclusion of noncitizens, most of whom are too poor to afford private schools for their children.

Poverty-based exclusion from education highlights the impossibility of alleviating poverty through education for all those who are too poor to afford its cost. This points to the need for an immediate and all-encompassing global commitment to eliminate the financial obstacles that impede free education for all

273. [T] spect to the children of immigrants. Immigrant parents report that they are often advised by Ministry of Education officials to seek to place their children in private fee-paying schools for one or two years until space opens up in a government school. This policy is not written down, but seems to have emerged purely as an attempt by Ministry officials to deal with the shortage of school spaces generated mainly by the recent tremendous influx into the country of so-called "economic migrants.

United Nations, Convention on the Rights of the Child, Committee on the Rights of the Child; Consideration of Reports Submitted by States Parties Under Article 44 of the Convention-Initial Reports of States Parties Due in 1995-Addendum: Antigua and Barbuda II 217, U.N. Doc. CRC/C/28/Add.22 (2003).

274. "[O]ver 1.5 million children attend the country's 6,800 public schools.... In addition to the students enrolled in public schools, about 1 million more attend private schools." UNITED NAtions, Economic and Social Council; Substantive Session of 1995-Implementation of the International Covenant on Economic, Social and Cultural Rights-Second Periodic Reports Submitted by States Parties Under Articles 16 and 17 of the Covenant-Addendum: Dominican Republic $192-93$, U.N. Doc. E/1990/6/Add.7 (1995).

275. "The poorest 40 percent of the population increased their ordinary expenditure on education by about 430 percent while the equivalent figure for the richest 5 percent was approximately 125 percent." United Nations, Convention on the Rights of the Child, Committee on the Rights of the Child; Consideration of Reports Submitted by States Parties Under Article 44 of the Convention - Initial Reports of States Parties Due in 1993-Addendum: DominiCAN Republic II 93, U.N. Doc. CRC/C/8/Add.40 (1999).

276. See Yean v. Dominican Republic, Case 12.189, Inter-Am. C.H.R. 61, OEA/ser. L./V./II.111, doc. 20 rev. 252 (2000).

277. "Primary education is thus free and compulsory for all school-age children, i.e. as from the age of seven. Secondary education is also free of charge." UNited Nations, supra note 274, at 191. 
school-age children. The basis of such a commitment is the increasing number of countries reintroducing free primary education at the turn of the millennium buttressed by the global prevalence of legal guarantees of the right to education. This would facilitate a global shift back to the original, rights-based model of progressive realization of the right to education.

\section{Bringing Back the Right to Education}

Free and compulsory education was linked by the International Labour Organization (ILO) to the elimination of child labor in $1921,{ }^{278}$ more than eighty years ago. The rationale was-and remains-that the right to education unlocks other rights when guaranteed, while its denial leads to compounded denials of other human rights and the perpetuation of poverty. The economic rationale for the right to education was-and remains-that investment in education should be made by the government because it yields economic returns with much delay. Moreover, education is not only, not even mainly, about the transmission of knowledge and skills. Education is a public good because it represents the most widespread form of institutionalized socialization of children. However, the economic underpinning of the right to education remains important because the denial of the right to education triggers exclusion from the labor market accompanied by the exclusion from social security owing to the prior exclusion from the labor market. Where the denial of human rights results in poverty, as it often does, and particularly in the case of girls and women, the remedy is necessarily the reaffirmation and enforcement of human rights, starting with the right to education.

Governments' obligation to adequately fund education exists so that children will not have to pay for their schooling or remain deprived of education when they cannot afford it. Children cannot control the aging process, hence their prioritized right to education in international human rights law; the damage of denying education while they are growing up is difficult, if not impossible, to remedy retroactively.

278. See ILO Convention No. C10, Minimum Age (Agriculture) Convention, Nov. 16, 1921, art. 1, available at http://www.ilo.org/ilolex/cgi-lex/convde.pl?C010 (last visited Sept. 17, 2004) (prohibiting employment that affects a child's school attendance and setting the minimum working age at 14); see also ILO Convention No. C138, Minimum Age Convention, June 26, 1973, art. 2 If 3, available at http://www.ilo.org/ilolex/cgi-lex/convde.pl?C138 (last visited Sept. 17, 2004) (stating that the minimum age of working "shall not be less than the age of completion of compulsory schooling and, in any case, shall not be less than 15 years.") 
Parents cannot ensure education for their children if they cannot afford the cost. If there are no parents, or if the parents are irresponsible, the government has to act in loco parentis, or children are doomed to be self-supporting from a tender age in contravention of the very notion of the rights of the child. Neither parents nor governments can ensure education for all children if it is beyond their means. Therefore, international human rights law mandates progressive realization of the right to education and prioritizes international cooperation toward that realization. This article has shown that global approaches to education vary and often undermine education as a human right. Hence there is a need for human rights mainstreaming.

Human rights mainstreaming has been endorsed by many global and domestic actors as well as individual governments. The EFA Global Monitoring Report 2003-2004 integrated human rights in its analytical framework; the WorldBank/IMF Development Committee has highlighted the need to "reinforce accountabilities." ${ }^{279}$ Such accountability stems from the symmetry between human rights guarantees and the corresponding governmental obligations. Its extension to the global level would facilitate the adjustment of non-rights-based global strategies to the human rights requirements. ${ }^{280}$

279. International Monetary Fund/World Bank Development Committee, Global Monitoring of Policies and Actions for Achieving the MDGs and Related Outcomes: Implementation Report I 22, DC2003-0013 (2003).

280. There have been many calls for using human rights as a yardstick for the assessment of macroeconomic policies as well as for bringing human rights to bear within the WTO. The Committee on the Rights of the Child has included in the reporting guidelines "[t]he measures taken to ensure that children, particularly those belonging to the most disadvantaged groups, are protected against the adverse effects of economic policies, including the reduction of budgetary allocations in the social sector." United Nations, Convention on the Rights of the Child, Committee on the Rights of the Child; General Guidelines Regarding the Form and Contents of Periodic Reports to be Submitted by States Parties Under Article 44, Paragraph 1 (b), of the Convention: Adopted by the Committee at its 343rd Meeting (Thirteenth Session) on 11 October 1996 I 20, U.N. Doc. CRC/ C/58 (1996). The Sub-Commission on the Promotion and Protection of Human Rights has called for "fully integrating human rights principles in the processes of economic policy formulation" and ensuring that "human rights principles and obligations are fully integrated in future negotiations in the World Trade Organization." United Nations, U.N. Subcommission on the Promotion and Protection of Human Rights; Trade Liberalization and its Impact on Human Rights, U.N. Doc. E/ CN.4/Sub.2/RES/1990/30 (1999). There has been global convergence on the need for public investment in primary education. For example, "primary education ought to be a priority for public spending on education in those countries that have low net enrollment." Sanjay Pradhan, Evaluating Public Spending: A Framework for Public Expenditure Reviews 10 (1996). After the turn of the millennium, there is also global consensus that primary education should be free. 
Since the turn of the millennium, there has been an emerging global consensus on the need to make primary education free, building on the pledge for all children to complete primary education. ${ }^{281}$ Thus far, the meaning of "free" has focused, at the global level, on identifying and eliminating direct charges that impede poor children's schooling and, in Latin America, on financial incentives for poor families to send their children to school and keep them at school, thereby addressing the opportunity costs of schooling as well. ${ }^{282}$ Different types of financial obstacles point to the necessity of a correspondingly broad definition of what free education should mean in practice. Indeed, the World Bank has changed its previous approach to acknowledge "that attainment of universal primary completion is a responsibility of national governments and that the children in any country that are currently out of school are those least able to contribute to the costs of education." 283

As mentioned above, the alleviation of unsustainable debt within the Enhanced Heavily Indebted Poor Countries Debt Relief Initiative (HIPC-II) has increased public funding for education. The requirement of PRSPs, the blueprints for the allocation of funds transferred from debt servicing to development, enhanced the visibility of education. Among the first twenty-five HIPC countries, ${ }^{284}$ direct charges in public primary education were mentioned in fourteen, and debt relief has been used for their complete or partial abolition, as de-

281. Similarities between the Millennium Development Goals and EFA commitments reflect the global consensus on the need for all children, by the year 2015, to be able to complete primary education and the need to eliminate gender disparities in education. Additional EFA commitments, such as the prolongation of education for all to encompass primary and lower secondary education (under the name of "basic education"), have not triggered a similarly broad global consensus. See United Nations Millennium Declaration, G.A. Res. 55/2, U.N. GAOR, 55th Sess., Agenda Item 60(b) If 19, U.N. Doc. A/RES/55/2 (2000).

282. See generally Samuel Morley \& David Coady, From Social Assistance to Social Development: Targeted Education Subsidies in Developing Countries (2003) (discussing a program that provides for the needs of poor families on the condition that they send their children to school).

283. Achieving Universal Primary Education by 2015: A Chance for Every Child, supra note 67 , at 81 .

284. These are Albania, Azerbaijan, Benin, Bolivia, Burkina Faso, Cambodia, Ethiopia, Ghana, Guyana, Honduras, Kyrgyzstan, Malawi, Mali, Mauritania, Mozambique, Nicaragua, Niger, Rwanda, Senegal, Sri Lanka, Tajikistan, Tanzania, Uganda, Vietnam and Yemen. Their PRSPs are available at www.worldbank.org/hipc. The HIPC process is lengthy, and numerous consecutive versions of PRSPs are furnished by the government. Typically, the first document is an interim PRSP, whose positive assessment by the IMF and the World Bank leads to the preparation 
scribed above in the regional review of Africa. The respective governments of only two countries, Ethiopia and Ghana, favored direct charges in primary education ${ }^{285}$ and continued them.

The process of debt relief has also encompassed the World Bank's FastTrack Initiative, launched in April 2002 for eighteen countries; ${ }^{286}$ all of them, with the sole exception of Gambia at that time, were also included in HIPC-II. These countries were to be "fast-tracked" toward the universalization of primary schooling. At a meeting of the World Bank, the United Nations Educational, Scientific and Cultural Organization, and the European Union, seven countries, Burkina Faso, Guinea, Guyana, Honduras, Mauritania, Nicaragua, and Niger, were selected for the first phase. ${ }^{287}$ These various initiatives have directed the spotlight on direct charges for primary education and the corresponding economic exclusion from education. Education cannot be expected to contribute to poverty eradication before education itself is rescued from poverty.

Human rights mainstreaming is a useful remedy for resolving conflicts between international human rights law and international trade law as well as to broaden the rule of law to encompass global macroeconomic, fiscal, and educa-

of the full PRSP, to be formally endorsed by the Boards of the IMF and the World Bank. A country's entry into the PRSP-supported program subsequently leads to the preparation, adoption, and endorsement of further PRSPs. IMF \& World Bank, International Monetary Fund and International Development Association, Heavily Indebted Poor Countries (HIPC) Initiative-Statistical Update (Mar. 31, 2004), available at http://www.imf.org/external/np/hipe/2004/033104.pdf (last visited Jan. 25, 2005).

285. See Addis Ababa, Federal Democratic Republic of Ethiopia (FDRE), Ministry of Finance and Economic Development (MOFED), Ethiopia: Sustainable Development and Poverty Reduction Program 89-97 (July 2002), available at http://siteresources.worldbank.org/INTETHIOPIA/ Overview/20207639/2002_07_prsp.pdf (last visited Jan. 25, 2005); Ghana Poverty Reduction Strategy 2003-2005, An Agenda for Growth and Prosperity 99-104 (Feb. 19, 2003), available at http:// poverty.worldbank.org/files/Ghana_PRSP.pdf (last visited Jan. 25, 2005).

286. The formal announcement of June 12, 2002 listed eighteen countries invited to join the FastTrack Initiave (FTI) (Albania, Bolivia, Burkina Faso, Ethiopia, Gambia, Ghana, Guinea, Guyana, Honduras, Mauritania, Mozambique, Nicaragua, Niger, Tanzania, Uganda, Vietnam, Zambia, and Yemen) and five to which the World Bank pledged intensified support so as to make them eligible for financing under the FTI (Bangladesh, Democratic Republic of Congo, India, Nigeria, and Pakistan). See Press Release, World Bank, World Bank Announces First Group of Countries for 'Education for All' Fast Track (June 12, 2002), News Release No. 2002/345/S, available at http:// www.worldbank.org.

287. See Press Release, World Bank, Education for All the World's Children: Donors Have Agreed to Help First Group of Countries on Education Fast-Track (Nov. 27, 2002), News Release No. 2003/155/ HD, available at http://www.worldbank.org (last visited Feb. 5, 2005). 
tional strategies. Domestically, solidarity is enforced through the duty to pay taxes that finance education. Internationally, the universality of the right to education is premised on international cooperation so as to equalize opportunities for the enjoyment of the right to education by supplementing insufficient resources of poor countries, communities, and families.

Government human rights obligations are premised on education's being a public good and institutionalized schooling a public service. Education as a universal human right requires governmental obligations on two levels: domestic and global. Individual states are responsible for ensuring that human rights are effectively safeguarded on their territory. Global educational strategies, economic or fiscal policies, international trade law, or anti-terrorism campaigns can constrain-rather than enhance-both the ability and the willingness of individual governments to guarantee the right to education. Hence, there is a need for human rights mainstreaming. It is, however, proverbial that we are much better at applying hindsight than foresight. Refocusing human rights research from retroactively remedying violations to preventing them is as urgent as it is neglected. The full mobilization of the existing human rights standards for education can neutralize negative dimensions of globalization at all levels, thus enabling the human rights community to provide a timely contribution to developments, which were, until recently, deemed to lie beyond the reach of human rights safeguards. 